Meta

Journal des traducteurs

Translators' Journal

\title{
De la tête aux pieds : les images anatomiques du français et de l'anglais
}

\section{Henri van Hoof}

Volume 45, numéro 2, juin 2000

URI : https://id.erudit.org/iderudit/004547ar

DOI : https://doi.org/10.7202/004547ar

Aller au sommaire du numéro

Éditeur(s)

Les Presses de l'Université de Montréal

ISSN

0026-0452 (imprimé)

1492-1421 (numérique)

Découvrir la revue

Citer cet article

van Hoof, H. (2000). De la tête aux pieds : les images anatomiques du français et de l'anglais. Meta, 45(2), 263-355. https://doi.org/10.7202/004547ar d'utilisation que vous pouvez consulter en ligne.

https://apropos.erudit.org/fr/usagers/politique-dutilisation/ 


\title{
ÉTUDES TERMINOLOGIQUES ET LINGUISTIQUES
}

\section{De la tête aux pieds: les images anatomiques du français et de l'anglais}

\author{
HENRI VAN HOOF \\ Centre de Terminologie de Bruxelles, Institut Libre Marie Haps
}

\begin{abstract}
Al Capone avait un bras droit d'une brutalité légendaire. Ce bras droit était un homme de main qui avait le bras long bien que privé de la main gauche dans une bagarre. Il n'y allait pourtant pas de main morte et tombait plutôt à bras raccourcis sur ses adversaires. Il était marié de la main gauche à une petite main qui lui cassait les pieds. Alors qu'il croyait l'avoir bien en main, il l'avait bel et bien sur les bras, ce qui faisait dire aux autres gros bras que ça lui ferait les pieds d'avoir perdu la main.
\end{abstract}

Cette petite histoire, inventée de toutes pièces pour illustrer notre propos, comment se traduirait-elle dans la langue de Shakespeare? L'anglais disposerait-il d'images analogues? Chaque peuple cristallise dans des formules imagées les observations d'une expérience accumulée au cours des siècles. La vitalité linguistique crée sans cesse de nouvelles locutions, de nouveaux dictons, et ces productions d'un imaginaire collectif, généralement anonyme (hormis quelques formules tirées de la Bible - de l'abondance du cour la bouche parle, eil pour oeil, dent pour dent, etc. ou d'auteurs célèbres comme Cicéron - autant de têtes autant d'avis, Juvénal — un esprit sain dans un corps sain, La Fontaine - il n'est pour voir que l'œil du maître, entre la chair et la chemise il faut cacher le bien que l'on fait, Montaigne - à chaque pied son soulier, Pascal — le nez de Cléopâtre, Marivaux — on n'est pas maître de son coeur, Scarron - être de la côte de saint Louis, Jules Renard - poil de carotte, etc.), n'ont manqué de puiser leurs symboles dans l'immense réservoir que constitue l'environnement naturel de l'homme. Et qu'y a-t-il de plus important dans cet environnement que l'homme lui-même, et de plus proche que son propre corps? Il nous a dès lors paru intéressant d'examiner les traces que l'anatomie humaine a pu laisser dans le langage imagé français et de vérifier dans quelle mesure elles épousent l’imaginaire de l'anglais.

\section{LE CORPUS}

L'inventaire proposé se limite aux locutions, dictons et proverbes inspirés par les différentes parties du corps et leurs acceptions dérivées appliquées à l'humain, à l'exclusion de leur transposition à l'animal et aux choses. On n'y trouvera donc pas des termes ou expressions tels que fesse-mathieu, cul-de-jatte, le nerf de la guerre, tordre le cou à une rumeur, ne pas y aller avec le dos de la cuiller, à cheval donné il ne faut pas regarder la bouche, sac plein dresse l'oreille, écorcher un pou pour en avoir la peau, être à deux doigts de la mort, avoir de la veine, pied à pied, prendre son pied,

Meta, $X L V, 2,2000$ 
vouloir être à cent pieds sous terre, ne pas céder d'un pouce, à l'ongle on connaît le lion, quand les poules auront des dents, avoir les yeux qui se croisent les bras, etc. Certaines locutions n'ont été retenues que pour l'un des symboles anatomiques y figurant; ainsi, dans les os lui sortent des doigts (c'est un joueur invétéré), seul doigt justifie la sélection, car os signifie ici «dés»; dans mentir cent pieds à la gorge (mentir effrontément), seul gorge justifie la sélection car pied est ici une unité de mesure, comme d'ailleurs dans faire un pied de nez (se moquer), retenu seulement en raison de nez; de même, dans si on lui en donne un pouce il en prendra grand comme le bras (il a tendance à abuser), seul bras justifie la sélection, car pouce aussi est ici une mesure; etc.

Les différentes parties du corps n'apparaissent que sous leur nom académique, à l'exclusion de toutes appellations non conventionnelles (pif, mirettes, guibolle, etc.). Une exception a été faite pour cul, couille et gueule, trois termes dont la force expressive a donné naissance à des composés et à des locutions bien plus nombreux que n'en ont engendré derrière, testicule et bouche.

Les entrées du corpus, classées dans l'ordre alphabétique sous chaque symbole anatomique, sont suivies de leur définition et rendues ensuite en anglais soit par un équivalent de même symbolique soit par une traduction simplement explicative.

\section{LA DATATION}

Puisées tant dans le passé que dans le présent, les entrées offrent, à côté de créations contemporaines, des tournures parfois très anciennes dont certaines sont toujours usitées, d'autres tombées en désuétude. Mais à partir de quel moment peut-on les qualifier d'obsolètes puisqu'il en est d'anciennes encore très actuelles, même s'il ne s'agit parfois que d'une survivance régionale: prendre en main $\left(\mathrm{XII}^{\mathrm{e}}\right)$, dresser l'oreille $\left(\mathrm{XII}^{\mathrm{e}}\right)$, pisser le sang $\left(\mathrm{XIII}^{\mathrm{e}}\right)$, ça lui pend au nez $\left(\mathrm{XIV}^{\mathrm{e}}\right)$, avoir la larme à l'œil $\left(\mathrm{xv}^{\mathrm{e}}\right)$, faire qqch pour les beaux yeux de qqn $\left(\mathrm{xv}^{\mathrm{e}}\right)$, faire la sourde oreille $\left(\mathrm{xv}^{\mathrm{e}}\right)$, s'en aller les pieds devant $\left(\mathrm{xv}^{\mathrm{e}}\right)$, avoir les dents longues $\left(\mathrm{xvI}^{\mathrm{e}}\right)$, il y a loin de la coupe aux lèvres $\left(\mathrm{xvI}^{\mathrm{e}}\right)$, fourrer son nez partout $\left(\mathrm{xvI}^{\mathrm{e}}\right)$, avoir les yeux plus grands que le ventre $\left(\mathrm{XVI}^{\mathrm{e}}\right)$, etc.; de même, en anglais: far from eye, far from heart ( $\left.\mathrm{xIII}^{\mathrm{e}}\right)$, fields have eyes, woods have ears $\left(\mathrm{xIII}^{\mathrm{e}}\right)$, the tongue breaks bone though itself has none $\left(\mathrm{xIII}^{\mathrm{e}}\right)$, stretch your legs according to your coverlet $\left(\mathrm{xIII}^{\mathrm{e}}\right)$, he makes a rod for his own back $\left(\mathrm{xIV}^{\mathrm{e}}\right)$, a scald head is soon broken $\left(\mathrm{xv}^{\mathrm{e}}\right)$, his hair grows through his hood $\left(\mathrm{xv}^{\mathrm{e}}\right)$, to have one's heart in one's boots $\left(\mathrm{xv}^{\mathrm{e}}\right)$, what the heart thinks the tongue speaks $\left(\mathrm{xv}^{\mathrm{e}}\right)$, two heads are better than one $\left(\mathrm{xvI}^{\mathrm{e}}\right)$, the tongue is not steel, yet it cuts $\left(\mathrm{xvI}^{\mathrm{e}}\right)$, etc.

Seules les expressions qui se rapportent à des choses ou des pratiques disparues depuis longtemps peuvent être vraiment qualifiées d'obsolètes: selon le bras la saignée, avoir les genoux bien graissés, être chatouilleux de la gorge, jouer à la main chaude, mettre la main à l'encensoir, se signer des orteils, se battre au premier sang, serrer les pouces à qqn, etc.; en anglais: to bless the world with one's heels, to top headless, etc.

Aussi nous bornerons-nous à indiquer, chaque fois que faire se peut, la date d'apparition ou la période d'utilisation approximatives de chaque entrée, en laissant au lecteur le soin d'apprécier leur degré de désuétude en fonction de sa culture langagière propre. Les dates citées sont d'ailleurs celles d'un repérage écrit et non celles d'une possible création, car l'apparition d'une locution dans un texte daté permet 
uniquement de conclure qu'elle existait à l'époque, alors qu'elle avait sans doute vécu déjà dans l'oral pendant de nombreuses années.

\section{LES NIVEAUX DE LANGUE}

Quand une expression est-elle familière, populaire, argotique, vulgaire? Les échelles de valeur varient selon les époques et les individus. Ces repères classiquement désignés comme niveaux de langue ne peuvent être que subjectifs et nous laisserons donc les habitudes langagières personnelles du lecteur décider de l'étiquette à coller sur chaque entrée.

\section{SIMILITUDES ET DIFFÉRENCES DU FRANÇAIS ET DE L'ANGLAIS}

Une comparaison entre les entrées françaises et leurs correspondants anglais permet de mettre en évidence la manière dont chaque langue met en œuvre les symboles anatomiques.

\section{Symboles anatomiques identiques}

Nombreux sont les cas où l'anglais utilise le même symbole anatomique que le français: demeurer bouche close/ to keep one's mouth shut, accueillir à bras ouverts/ to welcome with open arms, avoir le cour en bon lieu/ to have one's heart in the right place, s'en mettre plein le col/ to fill oneself up to the neck, lever le coude/ to lift the elbow, chatouiller les côtes à qqn, to tickle s.o.'s ribs, jouer des dents/ to ply one's teeth, montrer les dents/ to show one's teeth, perdre la face/ to lose face, mettre qqn à genoux/ to bring s.o. to his knees, en un clin d'ceil/ in the twinkling of an eye, quatre yeux voient plus que deux/ two eyes see more than two, s'en aller les pieds devant/ to go off feet foremost, pisser du sang/ to piss blood, faire mal au ventre à qqn/ to give s.o. a bellyache, etc.

Quelquefois, l'emploi du même symbole s'accompagne d'une précision supplémentaire: avoir la langue bien longue/ to have a tongue too long for one's mouth, montrer les talons/ to show a clean pair of heels, se taper la tête contre le mur/ to beat one's head against a brick wall, avoir la tête sur les épaules/ to have a good head on one's shoulders, etc.; ou à l'inverse, une précision se perd-elle: suer sang et eau/ to sweat blood.

Dans d'autres cas, un même symbole s'appuie sur une image différente: se mettre la corde au cou/ to put a halter round one's neck, faire l'épaule rennoise à qqn/ to give s.o. the cold shoulder, avoir un chat dans la gorge/ to have a frog in one's throat, avoir des fourmis dans les jambes/ to have pins and needles in the legs, n'être qu'un paquet d'os/ to be nothing but a bag of bones, la voix du sang/ the call of blood, avoir les talons courts/ to have round heels, sirop de vessiel bladder tea, etc.; ou sur un verbe différent: prendre qqn aux cheveux/ to comb s.o.'s hair, souffler aux oreilles de qqn/ to tickle s.o.'s ears, il ne faut toucher aux yeux que du coude/ you should never rub your eyes but with your elbow, etc.

Dans d'autres cas encore, seule une différence grammaticale distingue le français de l'anglais, le symbole anatomique restant inchangé. On relève ainsi des transpositions du nom au verbe: fourrer son nez/ to nose around, lire au poucel to thumb 
through a book, avoir qqn à l'ail/ to eyeball s.o., etc.; des transpositions du nom à l'adjectif: mariage de la main gauche/ left-handed marriage, avoir des yeux de lynx/ to be eagle-eyed, avoir des jambes en $\mathrm{X} /$ to be baker-legged, avoir les foies blancs/ to be lily-livered, revenir les mains vides/ to return empty-handed, etc.; des changements de préposition: avoir qqn dans la peau/ to have s.o. under one's skin, gagner haut la main/ to win hands down; ce dernier exemple annonce aussi les séries plus fournies constituées par le passage d'un symbole anatomique singulier en français au pluriel du même symbole en anglais: avoir la main baladeuse/ to have wandering hands, ventre affamé n'a point d'oreilles/ hungry bellies have no ears, avoir l'œil au guet/ to have all one's eyes about one, il faut faire le pas selon la jambe/ stretch your legs according to your coverlet, un cour chaud vaut mieux que des lettres de noblesse/ kind hearts are more than coronets, trinquer du nombril/ to wriggle navels, etc.; ou le passage d'un symbole pluriel en français au singulier du même symbole en anglais: il y a loin de la coupe aux lèvres/ there's many a slip 'twixt the cup and the lip, avoir les mains nettes en qqch/ to have no hand in sthg, attaquer qqn bec et ongles/ to go for s.o. tooth and nail, boucher ses oreilles/ to turn a deaf ear on, sourire jusqu'aux oreilles/ to smile from ear to ear, être pieds et poings liés / to be bound hand and foot, froid aux mains chaud au cour/ a cold hand and a warm heart, etc.

\section{Symboles anatomiques différents}

Tout aussi nombreux sont les exemples où le changement de symbole est soit total, une partie du corps se substituant à une autre, soit partiel, une partie du corps étant remplacée par l'un de ses constituants ou l'inverse. Ce sont autant de modulations.

\section{Modulation partie/ autre partie}

On trouve dans cette catégorie: être porté sur la bouche/ to make a god of one's belly, avoir le bras lourd/ to have broad shoulders, avoir les bras cassés/ to have no hinge in one's back, se mettre la cervelle à l'envers/ to eat one's heart out, tâter le biceps à qqn/ to tickle s.o.'s ears, faire compter les chevilles/ to leave s.o. to cool his heels, se donner des coups de pied dans les chevilles/ to give oneself a pat on the back, faire contre mauvaise fortune bon cœur/ to keep a stiff upper lip, haut les cœurs!/ chins up!, film de fessel skin flick, coûter la peau des fesses/ to cost an arm and a leg, avoir les dents longues/ to have itchy feet, avoir de l'estomac/ to have a nerve, tenir qqn à la gorge/ to have s.o. by the short hairs, jambe du milieu/ middle finger, en un tour de main/ in a flick of the wrist, se saigner des orteils/ to bless the world with one's heels, mouillé jusqu'aux os/ wet to the skin, avoir la peau trop courte/ to drop one's guts, raidir le jarret/ to turn up one's toes, marcher du bon pied/ to make a good fist at, prendre la voiture des frères Talon/ to take the shin-stage, se laver les tripes/ to wash one's neck, etc.

\section{Modulation tout/ partie}

Dans cette catégorie prennent place: il arrive bien des choses entre la bouche et le verre/ there's many a slip between the cup and the lip, accueillir qqn à bras ouverts/ to give s.o. the glad hand, avoir qqn sur les bras/ to have s.o. on one's hands, être le bras droit de qqn/ to be s.o.'s right hand, huile de bras/ elbow grease, lever les bras au 
ciel/ to throw up one's hands, prêter son bras/ to lend a helping hand, faire commerce de son corps/ to peddle flesh, to hawk one's arse, to sell the hips; avoir des mains de beurre/ to be a butterfingers, avoir la main verte/ to have a green thumb, marcher sur les pieds de qqn/ to step on s.o.'s toes, sécher sur pied/ to cool one's heels, traîner les pieds/ to drag one's heels, coup de poing/ knuckle-sandwich, casse-têtel brain-teaser, faire une tête/ to pull a long face, belle tête mais de cervelle point/ more hair than wit, etc.

\section{Modulation partie/ tout}

Non moins riche que la précédente, cette catégorie comprend: avoir le cerveau fêlé/ to be soft in the head, rompre la cervelle à qqn/ to make s.o.'s head split, avoir les cils cassés/ to have one's eyes draw straws, décharger son cour/ to make a clean breast of it, to get it off one's chest; on lui compterait les côtes/ he's a regular skeleton, se rincer les amygdales/ to wash one's neck, jeu de cuisses/ leg business, déchirer qqn à belles dents/ to badmouth s.o., avoir de l'esprit au bout des doigts/ to be clever with one's hands, entre l'arbre et l'écorce il ne faut pas mettre le doigt/ put not thy hand between the bark and the tree, avoir l'épiderme chatouilleux/ to be thin-skinned, les yeux sont le miroir de l'âme/ the face is the index of the heart, avoir le pied marin/ to have found one's sea-legs, à la force du poignet/ by sheer strength of the arm, etc.

\section{Absence de symbole anatomique en anglais}

Il ne manque évidemment pas de cas où l'anglais n'a pas d'équivalent anatomique pour traduire les images françaises inspirées par le corps humain : gouverner sa bouche selon sa bourse/ to cut one's coat according to one's cloth, avoir le bras long/ to have a wide influence, couper bras et jambes/ to bowl over, il y a un cheveu/ there's a fly in the ointment, y mettre le bras jusqu'au coude/ to commit oneself deeply, tiré par les cheveux/ far-fetched, être guéri du mal de dents/ to be out of all one's troubles, je n'en mettrais pas le doigt au feu/ I wouldn't swear it, faire le gros dos/ to ward off danger, changer son fusil d'épaule/ to change one's plans, avoir le feu aux fesses/ to be in a hurry, faire des gorges chaudes de/ to have a good laugh at, tenir la jambe à qqn/ to buttonhole s.o., donner sa langue au chat/ to give up guessing, applaudir des deux mains/ to approve unreservedly, se marier de la main gauche/ to marry over the broomstick, à vue de nez/ at first sight, se laver le bout du nez/ to give oneself a cat's lick, se regarder le nombril/ to be very pleased with oneself, avoir une coquetterie dans l'œil/ to have a slight squint, avoir la larme à l'œil/ to feel like crying, faire rubis sur l'ongle/ to do sthg thoroughly, avoir la puce à l'oreille/ to smell a rat, pisser son os/ to have an abortion, être mal dans sa peau/ to feel uncomfortable, avoir toujours le pied en l'air/ to be always on the go, d'arrache-pied/ without interruption, mettre qqn à pied/ to dismiss s.o., caresser qqn dans le sens du poil/ to smooth s.o.'s feathers, dormir à poings fermés/ to sleep like a log, pouce!/ break!, être chaud des reins/ to be a hot lover, pisser le sang/ to bleed profusely (à ne pas confondre avec pisser du sang/ to sweat blood), à tête reposée/ thinking it out carefully, avoir une idée derrière la tête/ to have an idea at the back of one's mind, chercher des poux dans la tête de qqn/ to pick on s.o., forte tête/ unruly fellow, n'en faire qu'à sa tête/ to have one's own way, se saigner aux quatre veines/ to bleed oneself white, être à plat ventre devant qqn/ to cringe before s.o., etc. 


\section{CALQUES, FAUX AMIS, JEUX DE MOTS}

Quelques locutions françaises apparues au cours de ce siècle ont été calquées littéralement de l'anglais: tom-pouce (1924)/ Tom Thumb umbrella, lavage de cerveau (1959)/ brainwashing, croiser les doigts (1970)/ to cross fingers, être né avec une cuiller d'argent dans la bouche $\left(\mathrm{xx}^{\mathrm{e}}\right) /$ to be born with a silver spoon in one's mouth (1639), etc.

Certaines équivalences apparemment parfaites entre locutions anatomiques françaises et anglaises peuvent n'être qu'illusoires. Ainsi, tenir son nez propre (ne pas parler à tort et à travers) est un faux ami de to keep one's nose clean (se conduire correctement); faire dieu de son ventre (être de mœurs légères, en parlant d'une femme) n'a rien de commun avec to make a god of one's belly (être gourmand); aller se faire couper les cheveux (aller au bordel) ne fait qu'évoquer to get one's hair cut (coïter) ; se casser le cou (tomber, se tuer) correspond à to break one's neck uniquement dans ce sens, pas dans celui de se hâter; chatouiller les oreilles à qqn (irriter qqn) n'a rien à voir avec to tickle s.o.'s ears (flatter qqn); main verte (talent de jardinage) est un faux ami de green hand (ouvrier inexpérimenté); se prendre en main (se ressaisir) est bien loin du sens de to take oneself in hand (se masturber).

Quelques expressions françaises sont le fruit de jeux de mots, pour lesquels l'anglais ne possède évidemment pas d'équivalent anatomique. Ainsi: département du bas rein (le postérieur) suggéré par le Bas-Rhin; ne connaître ni des lèvres ni des dents (ne pas connaitre du tout) par attraction de ni d'Ėve ni d'Adam; à qui veut jouir d'aile (lire: d'elle), il faut lever la cuisse (conseil à qui veut posséder une femme) par allusion au fait que pour bien trancher l'aile d'un poulet il faut d'abord en lever la cuisse; dos fin (proxénète) suggéré par dauphin; c'est le plus beau corps nu (il est cocu) par homonymie avec cornu; la corniche lui tombe dans l'oil (il a une veine de cocu) suggéré par corniche, diminutif de corne; mettre son corps en bière (boire de la bière) par calembour entre la boisson et le cercueil, etc. Inversement, l'anglais aussi se livre parfois à des jeux de mots similaires, comme dans la locution to be gone to Rot-His-Bone (être mort) inspirée par la ville de Ratisbonne.

\section{EN GUISE DE CONCLUSION}

Depuis toujours, la langue française a trouvé dans l'anatomie humaine un aliment qui a nourri sa création d'images. L'anglais ne le lui cède en rien. Mais un point par lequel le français s'en distingue est le recours à certains termes anatomiques savants. En effet, mis à part amygdales, que l'on trouve aussi en anglais dans se lécher les amygdales/ to box tonsils, le français est seul à utiliser des termes comme biceps (faire des effets de biceps, tâter les biceps à qqn), épiderme (avoir l'épiderme chatouilleux), mandibule (claquer des mandibules, jouer des mandibules), méninges (se creuser les méninges, ne pas se fouler les méninges), périnée (soutenir le périnée à qqn), péritoine (s'en faire éclater le péritoine), phalange (serrer la phalange à qqn), pylore (avoir une crampe au pylore), rotule (être sur les rotules).

\section{RÉFÉRENCES}

Augé, P. et al. (1931): Larousse du XX siècle, Paris, Larousse, 6 vol. _ (1960): Grand Larousse encyclopédique, Paris, Larousse, 10 vol. 
Berry, L. V. et M. Van Den Bark (1953): The American Thesaurus of Slang.

Browning, D. C. (1969): Dictionary of Quotations and Proverbs, Londres, Everyman's.

Brunet, F. et D. Mc Cavana (1996) : Dictionnaire bilingue de l'argot d'aujourd'hui, Paris, Pocket-

Langues pour tous.

CARAdec, Fr. (1988): N'ayons pas peur des mots, Paris, Larousse.

Cellard, J. et A. Rey (1991) : Dictionnaire du français non conventionnel, Paris, Hachette.

Colin, J.-P. et J.-P. Mével (1992) : Dictionnaire de l'argot, Paris, Larousse.

DeAK, F. (1962): Grand dictionnaire d'américanismes, Paris, Dauphin.

Dony, Y. de (1951): Léxico del lenguaje figurado, Buenos Aires, Desclee-De Brouwer.

Duneton, Cl. et S. Claval (1990): Le bouquet des expressions imagées, Paris, Seuil.

Esnault, G. (1965) : Dictionnaire des argots, Paris, Larousse.

Gréverand, J. L. et L. Greverand (1987) : Les portugaises ensablées, Louvain-La-Neuve, Duculot.

Guiraud, P. (1993): Dictionnaire érotique, Paris, Payot.

Leitner, M. J. et J. R. Lanen (1965) : Dictionary of French and American Slang, New York, Crown Publishing

Maloux, M. (1995): Dictionnaire des proverbes, sentences et maximes, Paris, Larousse.

Mansion, J. E. (1980): Harrap's Standard French-English Dictionary, Londres, Harrap, 4 vol.

Marks, J. (1971): Harrap's French-English Dictionary of Slang and Colloquialisms, Londres, Harrap.

Monteyrand, Fl. et al. (1984): Dictionnaire de proverbes et dictons, Paris, Dictionnaires Le Robert. Onions, C. T. (1969): The Shorter Oxford English Dictionary, Oxford, Clarendon Press, 2 vol.

Partridge, E. (1961): A Dictionary of Slang and Unconventional English, London, Routledge \& Kegan Paul, 2 vol.

Perret, P. (1991): Le nouveau petit Perret, Paris, Cl. Lattès.

Phythian, B. A. (1986): A Concise Dictionary of English Slang, London, Hodder \& Stoughton.

Rey, A. et al. (1992): Dictionnaire historique de la langue française, Paris, Dictionnaires Le Robert, 2 vol.

Rey, A. et Chantreau (1997): Dictionnaire des expressions et locutions, Paris, Dictionnaires Le Robert

SAndry, G. et M. Carrère (1953): Dictionnaire de l'argot moderne, Paris, Productions de Paris. Schmidt, J. E. (1959): Dictionary of Medical Slang, Springfield (Ill.), Charles C. Thomas.

Spears, R. A. (1991): A Dictionary of Slang and Euphemisms, New York, Signet Penguin Books

Stevenson (1949): Stevenson's Book of Proverbs, Maxims and Familiar Phrases, Londres, Routledge \& Kegan Paul.

Wentworth, H. et S. B. Flexner (1960): Dictionary of Slang, New York, Crowell. 


\section{ANNEXE}

\section{AISSELLE}

blague sous les aisselles! (1867) sérieusement!; (E) no kidding! vous devenez bête, le poil vous vient sous les aisselles (1640)

vous voilà pubère; (E) you are getting hair in your private parts

\section{AMYGDALES}

s'arroser/ s'humecter/ se rincer les amygdales (1881)

boire; (E) to kill a few brain cells (US), to bend/ crook/ lift/ raise the elbow, to wet an/ the eye, to soak/ suck one's face, to lift/ tip the little finger, to rinse one's gums, to get/ put one's head in a bag, to suck out a few heads (US), to put it down one's neck, to wash one's neck, to rinse one's teeth, to moisten one's throat

se caler les amygdales (1986)

(bien) manger; (E) to feed/ stuff one's face, to put sthg down one's gullet, to guts up, to fill oneself up to the neck, to put one's nose in the manger, to line one's stomach, to ply one's teeth

se lécher/ se sucer les amygdales (20) pratiquer le baiser lingual; (E) to chew face (US), to mouth, to hot-tongue (US), to give a tongue-kiss, to box tonsils (US), to play at tonsil hockey (US), to swab s.o.'s tonsils (US) ANUS

apôtre de l'anus (1864)

homosexuel actif; (E) arse-king, eye doctor, eye-opener, gut-butcher, gut-fucker, gutmonger, gut-reamer, gut-scraper, gut-sticker, gut-stretcher, gut-stuffer, broken-wrist, limpwrist

mettre un serpentin à l'anus (20)

pratiquer la sodomie; (E) to ass-fuck

\section{ARTÈRE}

on a l'âge de ses artères

l'âge ne se lit pas sur l'apparence; (E) man is as old as he feels

\section{BARBE}

à la barbe de qqn (15)

en présence et en dépit de qqn; (E) right to s.o.'s face/ under s.o.'s nose

à la barbe du palefrenier qui panse la bête

(1640)

se disait de qqn qui rote et qui pète; (E) said of s.o. who burps and farts

avoir de la barbe (au menton) (1872) avoir atteint l'âge viril; (E) to have reached puberty avoir sa/ une barbe (18)

être ivre; (E) to be pissy-arsed, to be ratarsed, to be arseholed, to be on one's ass, to be cut in the back, to have a turkey on one's back, to be belly-up, to be out of one's brain, to have one's brain in a leash, to be smashed out of one's brains, to be on one's ear, to be slopped/sloshed to the ears, to be bright/ dull in the eye, to have a drop in the eye, to be bung-eyed/ cock-eyed/ cross-eyed/goreyeyed/ hoary-eyed/ moon-eyed/ nine-eyed/ oary-eyed/ owly-eyed/ pee-eyed/ pie-eyed/ soapy-eyed/ wall-eyed, to be with/ have one's/ the eyes set (in one's head), to have (got) the sun in one's eyes, to be looped/ stewed to the eyeballs, to be pissed to the eyebrows, to be pissy-faced drunk, to be shit-faced, to be cut over the head, to have a swollen head, to have corns in the head, to have got a spur in one's head, the tavern-bitch has bit him in the head, to be heeled, to be knee-walking, to be cut in the leg, to have cut one's leg, to be legless, to be loop-legged, to make indentures with one's legs, to be off the nail, to be shot in the neck (US), to be what-nosed, to have (got/ had) a skinful, to be out of one's skull, to have one's backteeth awash/ under water, to have one's teeth well afloat

avoir son extrait de barbe (1872) (cf. ci-dessus)

barbe

1. ivresse (1712); (E) drop in the eye, skinful

2. chose ou personne ennuyeuse (1881); (E) pain in the arse/ ass, headache, stick-jaw, pain in the neck 3. poils du pubis féminin (1930); (E) silent beard

barbe à poux (19) individu malpropre; (E) untidy fellow

barbe d'avocat, qui croît par articles (1640) barbe inégale par endroits; (E) uneven beard

barbe de jardinier, qui croît par bouquets (1640) (cf. ci-dessus)

barbe en couenne de lard (1640) barbe courte et drue; (E) short, stubby beard barbe rousse, noir de chevelure est réputé faux de nature (1568)

il faut se méfier des roux; (E) redheads are unreliable

c'est la barbe et les cheveux! (1910)

1. c'est mortellement ennuyeux; (E) it gives one a pain in the neck, it's getting on one's nerves 
2. c'est infiniment fastidieux; (E) it's a neverending job

du côté de la barbe est la toute-puissance l'homme est le maitre dans le ménage;

(E) the husband is the master of the household

en la grande barbe ne gît pas le savoir (13)

(cf. longue barbe, courte science)

essuyez votre barbe et dites-moi ce que vous avez bu (1640)

formule de refus à une demande;

(E) expression of refusal to a request faire la barbe à qqn

1. l'emporter sur qqn (1640); (E) to have the upper hand of s.o., to have a leg up on s.o.

2. braver, provoquer qqn (1690); (E) to dare s.o.

3. faire affront à qqn (1690); (E) to send s.o. away with a flea in his ear, to bite s.o.'s head off, to bite s.o.'s nose off, to put s.o.'s nose out of joint, to jump down s.o.'s throat 4. narguer, se moquer de qqn (1792); (E) to make a long nose at s.o., to thumb one's nose at s.o., to bite the thumb at s.o., to put/ stick out one's tongue at s.o.

5. guillotiner qqn (1795); (E) to behead s.o. 6. exaspérer qqn (1866); (E) to annoy the arse off s.o., to be on/ up s.o.'s ass (US), to gripe/ ride s.o.'s ass (US), to be/ get/ ride on s.o.'s back, to give s.o. the bellyache, to get into s.o.'s hair, to give s.o. a pain in the neck, to get on s.o.'s nerves/ tits, to get up s.o.'s nose, to give s.o. a pain in the penis, to get under s.o.'s skin

faire qqch à la barbe de qqn (15)

faire qqch par bravade; (E) to do sthg in front of s.o.'s very face, to do sthg right to s.o.'s face, to do sthg under s.o.'s very eyes/ very nose

faire une barbe à qqn (1968)

duper, mystifier qqn ; (E) to ride on s.o.'s back, to blear the eyes of s.o., to throw dust in the eyes of s.o., to make faces at s.o., to wipe s.o.'s nose

il faut qu'il s'en torche la barbe il n'aura pas ce qu'il désirait; (E) he will not get what he wanted

il se laisserait arracher la barbe poil à poil (1690) c'est un lâche, un poltron; (E) he is a yellow belly, he has cold feet

jeune barbe (1640)

jeune sans expérience; (E) tenderfoot

la barbe! (1881)

1. vous m'ennuyez; (E) you are giving me the bellyache!, you are getting into my hair!, you are giving me a pain in the neck!, you are getting on my nerves!

2. taisez-vous!; (E) button/ shut your face! hold your jaw!, button your lip!

la barbe lui croît devant l'entendement comme aux chèvres de Brie (17)

l'expérience n'accompagne pas une barbe tôt venue; (E) experience does not come with a beard grown young

la barbe lui en fume (1794)

1. il est très en colère; $(\mathrm{E})$ he has a monkey on his back, his back is up, the blood rushed to his head

2. il est fort dépité; (E) he is very sore

la barbe ne fait pas l'homme (17)

il ne faut pas se fier aux apparences; (E) if

the beard were all, the goat might preach

longue barbe, courte science (17)

une longue barbe n'est pas signe de savoir;

(E) a long beard is no sign of erudition

maint fol a une barbe (13)

(cf. la barbe ne fait pas l'homme)

marmonner dans sa barbe

parler de manière indistincte; (E) to say sthg between one's teeth

prendre sa/ une barbe (1702)

s'enivrer; (E) to get pie-eyed (US), to get

pissy-eyed, to wash one's face in an ale clout, to cop a head (US), to cut one's leg

quelle barbe! (19)

quelle chose/ personne ennuyeuse; (E) what a pain in the ass/ neck!

rire dans sa barbe (18)

rire sans le montrer; (E) to laugh up one's sleeve

se laisser arracher la barbe poil à poil (1690) subir tous les affronts par lâcheté; (E) to swallow every rebuff out of cowardice

se mettre une fausse barbe (1970) pratiquer le cunnilinctus; (E) to do a face job (US), to give face (US), to play mouthmusic, to tongue (-fuck), to do a tongue job vieille barbe (19)

vieillard ennuyeux, personne vieux jeu;

(E) mossback (US)

vous avez la barbe trop jeune! (1690)

se disait à qqn qui prétend en remontrer à plus âgé que lui; (E) said to s.o. who thinks he can reprove an older person

BICEPS

avoir du/ des biceps (19)

avoir une grande force physique; (E) to be strong in the arm, to have plenty of brawn 
faire des effets de biceps (1867)

1. frapper; (E) to thrash

2. menacer, montrer sa force; (E) to

threaten, to show one's strength

tâter le biceps à qqn (1851)

prendre qqn par la flatterie; (E) to piss down s.o.'s back, to back-scratch s.o., to tickle s.o.'s ears

\section{BOUCHE}

à bouche que veux-tu (1649)

à profusion; (E) to one's heart content

avoir bonne bouche (1640)

ne rien avouer; (E) to confess nothing

avoir de la bouillie dans la bouche (19)

(cf. marmonner dans sa barbe)

avoir l'eau à la bouche (15)

saliver d'envie, se délecter à l'avance; (E) to

make one's mouth water

avoir la bouche pleine de dents

(cf. avoir les dents longues 2)

avoir le cœur à la bouche (1842)

s'exprimer avec franchise, sans réserve;

(E) to speak with open heart, to speak openheartedly, to wear one's heart on one's sleeve

avoir qqch constamment à la bouche répéter toujours la même chose; (E) to keep on repeating sthg

baisez-moi le cul, la bouche est malade! (1640) formule grossière de refus; (E) kiss my arse! bouche à bouche

1. vis-à-vis l'un de l'autre (13); (E) eyeball to eyeball, face to face

2. technique de réanimation $(20) ;(E)$

mouth-to-mouth resuscitation

bouche bée (1880)

la bouche grand ouverte; (E) with parted

lips, open-mouthed

bouche chaude (1970)

fellation; (E) head-job

bouche cousue! (15)

ne dites rien!; (E) finger on the lips!, button your lip! (US)

bouche de miel, cœur de fiel

les paroles flatteuses cachent souvent de mauvais sentiments; (E) a honey tongue, a heart of gall

bouche d'en bas (1864)

sexe de la femme; (E) belly-dale, belly-dingle, belly-entrance, eye that weeps most when best pleased, long-eye, jack nasty face, (old) mossy face, gut-entrance, hair, hair-burger (US), hair -court, hair-pie (US), nether lips, mouth that cannot bite, mouth that says no words about it, thankless mouth, skin-coat bouche en cœur au sage, cœur en bouche au fou (1557)

le sage mesure ses paroles; (E) the wise man bridles his tongue; wise men have their mouths in their hearts, fools have their hearts in their mouths

cela me revient à la bouche (17)

cela me dégoûte, me rend malade; (E) it makes my gorge rise, it's enough to have my heart up, it turns my stomach

clore la bouche à qqn (1640) faire taire qqn; (E) to silence s.o.

de bouche à oreille (19) avec discrétion, en secret; (E) by word of mouth

de broc en bouche (1640) immédiatement, promptement; (E) straight off

de l'abondance du cœur la bouche parle

(Matthieu, 12, 34; 1690) nous parlons souvent de ce qui nous touche le plus; (E) nearest the heart, nearest the mouth; what the heart thinks the tongue speaks; when the heart is afire some sparks will fly out of the mouth

déesse aux cent bouches (17)

la renommée; (E) fame

demeurer bouche bée (1886) être frappé de stupéfaction; (E) not to believe one's eyes, to have one's eyes stick out like organ-stops, to stare with eyes like saucers, to be wide-eyed, to stand openmouthed, to stand with mouth half-cocked

demeurer bouche close/ cousue (1690) se taire; (E) to button up/ to shut one's face, to button one's lips, to keep one's lip buttoned, not to open one's lips/ mouth, to keep one's mouth shut, to have lost one's tongue, to hold one's tongue, to keep one's tongue between one's teeth

demeurer sur la mauvaise bouche rester sur une impression finale désagréable; (E) to have a nasty taste in the mouth

dire de bouche (1640) dire soi-même; (E) to tell personally douce parole n'écorche pas la bouche (1568) (cf. beau parler n'écorche pas la langue) elle s'écoute parler, elle a la bouche près des oreilles (1640)

elle a une grande bouche; (E) she has a big mouth

en avoir plein la bouche de qqch/ qqn (1804) en parler avec enthousiasme; (E) to be full of sthg/ s.o. 
en bouche close n'entre mouche (1610)

le silence est une vertu; (E) a still tongue makes a wise head

en matière d'aumône, il faut fermer la bouche et ouvrir le cœur (1598)

il faut faire le bien discrètement; (E) good must be done modestly

entre bouche et cuiller vient bien encombrier (13)

(cf. il arrive bien des choses entre la bouche et le verre)

épargne de bouche vaut rente de pré

l'économie dans les dépenses de la table est aussi avantageuse qu'un bon revenu;

(E) saving on food is as good as an income être fort en bouche (1690)

parler avec hauteur ou insolence; (E) to speak haughtily or arrogantly

être né avec une cuiller d'argent dans la bouche (20)

être né dans un milieu aisé; (E) to be born with a silver spoon in one's mouth

être (porté) sur la bouche (1640) aimer la bonne chère; (E) to make a god of one's belly

faire la bouche en cour (19)

minauder, parler avec affectation; (E) to mince (one's words)

faire la bouche en cul de poule (1894)

(cf. ci-dessus)

faire la fine bouche (18)

se montrer difficile; (E) to be dainty

faire la petite bouche (1466)

1. cf. faire la fine bouche

2. cf. faire la BOUCHE en cour

3. manger sans appétit; (E) to have no stomach for one's food

4. être sobre en paroles; (E) to be sparing of words

faire venir l'eau à la bouche (16)

faire naître le désir de qqch; (E) to make one's mouth water

fermer la bouche à qqn (17)

(cf. clore la bouche à qqn)

fine bouche

gourmet; (E) gourmet

garder pour la bonne bouche (1640)

1. réserver le plus agréable pour la fin; (E) to keep sthg as a titbit

2. garder en mémoire pour se venger; (E) to

keep in mind with thoughts of revenge

gouverner sa bouche selon sa bourse (1640)

dépenser selon ses moyens; (E) to stretch one's legs according to one's coverlet il a la langue à la bouche et non à la bourse (1640)

il promet beaucoup et ne donne rien; (E) a long tongue is a sign of a short hand il arrive bien des choses entre la bouche et le verre (18)

les imprévus ne sont pas rares dans la vie;

(E) there's many a slip 'twixt the cup and the lip

il dit cela de la bouche, mais le cœur n'y touche (17)

il parle contre sa pensée; (E) he pays lip service

il faut une aiguille pour la bouche et deux pour la bourse (1842)

le mauvais usage de l'argent est moins nuisible que celui des paroles; (E) evil words are more harmful than a wrong use of money

il l'a tiré de mon cul pour le mettre à sa bouche (1640)

il se sert de mes propres paroles; (E) he heard me say that before

il n'a ni bouche ni éperon

1. il est grossier, impertinent (1640); (E) he is rude, impudent

2. il n'est bon à rien (1690); (E) he is a good-for-nothing

il ne faut pas tant baiser son ami à la bouche que le cœur lui fasse mal (1640)

il ne faut pas importuner un ami jusqu'à ce qu'il se fâche; (E) a friend must not be obtruded on until he gets angry

il nous arracherait volontiers les morceaux de la bouche (1640)

c'est un glouton; (E) he is a greedy guts/ guzzle-guts

je ris de la bouche (17)

réponse à un curieux qui demande pourquoi l'on rit; (E) reply to s.o. who asks for the reason of one's laughing

la bouche n'a pas de dimanche la bouche n'est jamais au repos; (E) the mouth is never at rest

la bourse ouvre la bouche (1568) l'argent fait parler; (E) money loosens the tongue

la langue du sage est dans son cœur, le cœur du sot est dans sa bouche (cf. BOUCHE en cœur au sage)

la parole ne lui meurt pas dans la bouche (17) il est éloquent; c'est un beau parleur; (E) he has a glib/ ready/ slick/ smooth tongue, his tongue is well hung, his tongue runs on wheels 
la vérité sort de la bouche des enfants les enfants parlent sans calcul; (E) children and fools tell the truth

large de bouche et étroit de ceinture (1640)

(cf. il a la langue à la BOUCHE et non à la bourse)

les bouches inutiles (19)

les improductifs, les oisifs; (E) the idlers, the inactive people

les paroles lui croissent à la bouche (1640)

(cf. la parole ne lui meurt pas dans la bouche)

loucher de la bouche (1867)

avoir le sourire faux; (E) to smile hypocritically

miel sur la bouche, fiel au cœur

(cf. BOUCHE de miel, cour de fiel)

ne pas faire la petite bouche (1690)

(cf. avoir le cœur à la BOUCHE)

ne pouvoir tirer un mot de la bouche de qqn ne pas réussir à faire parler qqn; (E) to be unable to make s.o. talk

ouvrir la bouche

commencer à parler, prendre la parole;

(E) to start speaking

prendre sur sa bouche épargner sur la nourriture; (E) to save on food

qu'un autre te loue et non ta bouche (Livre des Proverbes, 27,2)

il faut se garder de vanter ses propres mérites; (E) never praise thyself

qui garde sa bouche garde son âme (Livre des

Proverbes, 13,3)

il faut surveiller ses paroles; (E) the tongue speaks at the head's cost

qui n'a pas d'argent en bourse, qu'il ait du miel en bouche (1592)

faute d'argent, il faut user de persuasion;

(E) honey in the mouth saves the purse rester bouche bée (1886)

(cf. demeurer bouche bée)

retirer le pain de la bouche de qqn (19)

enlever les moyens de subsistance à qqn;

(E) to take the bread out of s.o.'s mouth

s'enlever les morceaux de la bouche pour qqn se priver pour qqn; (E) to deny oneself for s.o.

sa bouche dit à ses oreilles que son menton touche son nez (1842)

il/ elle est d'une laideur extrême; (E) he/ she is a face-ache, he/ she is handsome-bodied in the face, he/ she is fiddle-headed son nom est dans toutes les bouches il est très connu; tout le monde parle de lui; (E) his name is on every tongue

ta bouche, bébé (t'auras une frite)! (20) tais-toi!; (E) shut your face!, put your head in a bag!, shut your head!, hold you jaw!, button your lip!, shut your mouth!, shut your neck!, wind your neck in! hold your tongue!

table sans sel, bouche sans salive (1610) le goût de la vie se perd si elle est fade et monotone; (E) salt seasons all things tard la main à la bouche quand la parole est issue (13)

les paroles dites ne se rattrapent pas;

(E) spoken words cannot be retrieved

tourner sept fois sa langue dans sa bouche (avant de parler) (1835)

parler avec circonspection; (E) to think twice before speaking

traiter qqn à bouche que veux-tu (17) régaler qqn; (E) to feast s.o.

va-de-la bouche (19) goinfre; (E) belly-gut, gobble-guts, greedy guts, guzzle-guts

voler de bouche en bouche se répandre par la parole (nouvelle, rumeur); (E) to spread around (news, rumour) BOYAU

aimer qqn comme ses petits boyaux (1640) aimer profondément, tendrement; (E) to cherish s.o. like the apple of one's eye avoir (toujours) un boyau de vide/ des boyaux vides (1867) avoir (toujours) faim; (E) to be (always) belly-pinched, to have a wolf in one's belly/ stomach, to have an empty stomach

boyau, gros boyau (1864) membre viril; (E) short/ small arm, arseopener, arse-wedge, beard splitter, bellyruffian, my body's captain, (jiggling-) bone, eye-opener, one-eyed brother/ milkman/ monster/ pants mouse/ trouser snake/ worm/ zipper snake, little/ middle finger, potatofinger, gut-stick, hair-divider, hair-splitter, head, bald-headed hermit, heart, kidneyscraper, kidney-wiper, best leg of three, down-leg, middle/ third leg, marrow-bone, marrow-pudding, muscle of love, skin-diver, skin flute

boyaux de la tête (19)

le cerveau; (E) the brain

c'est à (faire) vomir tripes et boyaux (1690) c'est dégoûtant, répugnant; (E) it's enough 
to have one's heart up/ to turn one's stomach il a toujours une aune/ dix aunes de boyaux vides pour festoyer (1640)

il a toujours bon appétit; (E) his appetite is always good

mes boyaux crient vengeance (1640)

j'ai très faim; (E) I could take up the slack of my belly and wipe my eyes with it, my belly thinks my throat is cut, my belly-button is playing hell with my backbone, my guts chime twelve, my guts curse my teeth, my great guts are ready to eat my little ones, the stomach-worm gnaws

rendre tripes et boyaux (1640)

vomir; (E) to air one's belly, to bring up one's guts, to puke/ spew one's guts up, to shit through one's teeth, to throw up one's toenails (US)

tord-boyaux

alcool fort ou de mauvaise qualité; (E) bellywash, tickle-brain, eyewash (US), red eye (US), white eye, tanglefoot, rotgut, gut-rot, hair-curler, tangle-leg, tonsil bath/ paint (US)

\section{BRAS}

à bout de bras avec effort, sans aide; (E) at arm's length

à bras (d'homme) sans recours à d'autres moyens; (E) by hand

à plein bras (1640)

de toute sa force, avec énergie; (E) with all one's strength

à tour de bras (1587)

(cf. ci-dessus)

accueillir qqn à bras ouverts (1606)

faire bon accueil à qqn; (E) to greet /

receive/ welcome s.o. with open arms, to give s.o. the glad hand (US)

aimer plus la manche que le bras (1842)

aimer mieux son argent que soi-même, être avare; (E) to be hard-assed, to be a mingyarsed bastard, to be tight arsed/ assed(US), to be close-fisted, to have a cramp in the hand, he wouldn't give you the scrapings of his nails, to be a skin-flint

allonger le bras (1640)

demander l'aumône, mendier; (E) to have one's hand out (US)

allonger le bras vers qqch

faire l'effort de saisir qqch; (E) to make a long arm for sthg

arrêter le bras de qqn

empêcher qqn de sévir; (E) to stay s.o.'s hand

avoir des bras en saindoux

manquer de vigueur, d'énergie; (E) to lack

stamina avoir le bras long (19)

avoir de l'influence; (E) to have a long arm

avoir le bras lourd

avoir d'amples moyens financiers; (E) to

have a broad back, to be well-heeled (US), to have broad shoulders

avoir les bras cassés (19)

être paresseux; (E) to have lead in one's ass

(US), not to break one's back, to have no

hinge in one's back, to be bone-idle, to have a bone in one's arm/ in the knee/ in one's leg, to be a lazy-bones

avoir les bras en pâté de foie

(cf. avoir des bras en saindoux)

avoir les bras longs (1789)

(cf. avoir le bras long)

avoir les bras pendants (1690)

(cf. avoir les bras cassés)

avoir les bras retournés (19)/ à la retourne (20)

(cf. avoir les bras cassés)

avoir les bras rompus (1690)

être exténué; (E) to be on one's ass (US), to be flat on one's back (US), to drag one's bottom, to be crawling/ to crawl on one's eyebrows, to be hardly capable of putting one foot in front of the other, to be out on one's feet, to be on one's last legs

avoir les bras trop courts (1690) n'être pas à même d'achever une entreprise; (E) not to be able to finish a job

avoir les gros bras (1873)

(cf. avoir du biceps)

avoir qqch/ qqn sur les bras (17) avoir à sa charge; (E) to have sthg/ s.o. on one's back/ on one's hands

avoir un bras dans le sac (20) être handicapé, infirme; (E) to be physically handicapped

baisser les bras (20)

abandonner, renoncer; (E) to turn one's back on, to chuck/ throw in one's hand, to put one's hands up, to throw up the head

bras (16)

(cf. boyau)

bras cassé (20)

propre à rien; raté; (E) good-for-nothing; washout

bras de fer (20) épreuve de force; (E) strength test

bras dessus, bras dessous (1605) en se donnant le bras; (E) arm in arm

casser/ couper bras et jambes (19)

frapper de stupeur, laisser sans réaction; (E) to knock s.o. off his feet, to hit/ poke/ smite under the fifth rib 
demeurer les bras croisés (1640)

1. rester inactif, se complaire dans l'oisiveté;

(E) to sit on one's arsel on one's hands (US), to kick one's heels, to twiddle one's thumbs

2. ne pas intervenir; (E) not to lift one's little finger, not to take a hand

droit comme mon bras quand je me mouche (1894)

tout de travers; (E) all askew, crooked

en avoir plein les bras

avoir fort à faire, être très occupé; (E) to be run off one's feet, to have one's hands full, to be run off one's legs

être dans les bras de Morphée (19)

dormir; (E) to be in the arms of Morpheus, to pound one's ear, to get some shut-eye, to get one's head down

être le bras droit de qqn (1801)

être le principal collaborateur de qqn; (E) to be s.o.'s right hand

être sur les bras de qqn (17)

1. être à la charge de qqn; (E) to be on s.o.'s hands

2. être un embarras pour qqn; (E) to be on s.o.'s back

faire les beaux bras

affecter les belles manières; (E) to affect refined manners

faire les gros bras (1957)

(cf. faire des effets de biceps)

faire un bras d'honneur (1950)

faire un geste de défi ou de mépris grossier; (E) to give s.o. the finger (US)

faire une tête longue comme le bras

1. bouder, faire grise mine; (E) to make a face (as long as a fiddle), to pull a long face, to hang one's lips, to look down one's nose 2. avoir l'air abattu; (E) to have a black dog on one's back, to have an eye in a sling, to have one's heart in one's boots, to be down in the mouth

gros bras (1924)

homme fort; (E) strong-arm, muscleman gros comme le bras (1660)

amplement, sans lésiner; (E) amply, excessively

huile de bras (1866) vigueur physique; (E) elbow-grease

il se mangerait plutôt les bras jusqu'au coude (1640)

il n'est pas du genre à renoncer; (E) it's not like him to give up

il vaut mieux allonger le bras que le col (1640)

mieux vaut mendier que de risquer la pendaison pour vol; (E) it's better to beg than to risk being hanged for stealing

jouer les gros bras (1957)

(cf. faire des effets de biceps)

laisser tomber les bras (20)

(cf. baisser les bras)

les bons bras font les bonnes lames toute arme est bonne entre les mains du brave; (E) any weapon will do in the hands of the brave

les bras m'en tombent (19)

1. je suis stupéfait; (E) I am flabbergasted

2. je suis épuisé; (E) I am exhausted

lever les bras au ciel (17)

1. implorer la miséricorde divine; (E) to raise one's hands to heaven

2. manifester son étonnement ou son impuissance; (E) to throw up one's hands

manche désirée fait court bras (13)

on ne jouit plus du désir réalisé; (E) wishes, soon as granted, fly

manquer de bras avoir trop peu de personnel; (E) to be shorthanded

mettre le bras jusqu'au coude (1640) s'engager bien avant, complètement; (E) to commit oneself deeply

ouvrir les bras à qqn

(cf. accueillir à bras ouverts)

prendre qqn à bras-le-corps (1784)

1. saisir qqn par la taille; (E) to seize s.o.

round the waist

2. maltraiter, molester qqn; (E) to manhandle s.o.

prendre qqch à pleins bras enserrer qqch dans ses bras; (E) to fill one's arms with sthg

prendre qqn à plein bras étreindre qqn; (E) to fling/ throw one's arms around s.o.

prêter son bras (1640)

aider, prêter son assistance; (E) to offer one's arm, to lend a (helping) hand, to give a leg up, to put a shoulder to the wheel

recevoir qqn à bras ouverts (1606)

(cf. accueillir à bras ouverts)

rester les bras ballants (17)

(cf. demeurer les bras croisés )

rester les bras croisés (1640)

(cf. ci-dessus)

rompre bras et jambes à qqn

frapper qqn avec violence; (E) to give s.o. a shirt full s.o. sore bones, to knock s.o.'s head, to beat s.o. hip and thigh, to tickle s.o.'s ribs, to skin s.o. alive, to go for s.o. tooth and nail 
saisir qqn à bras-le-corps (1791)

(cf. prendre qqn à bras-le-corps)

se croiser les bras (1604)

1. cf. demeurer les bras croisés

2. refuser d'agir; (E) to cross/ fold one's arms

se jeter dans les bras de qqn

1. embrasser qqn avec effusion; (E) to hug

s.o. effusively

2. se mettre sous la protection de qqn; (E) to seek s.o.'s protection

se mettre qqch sur les bras (17)

s'attirer des ennuis; (E) to bring sthg on oneself

se mettre qqn sur les bras (17)

s'attirer l'hostilité de qqn; (E) to make an enemy of s.o.

selon le bras (fais) la saignée (1597)

il faut adapter ses dépenses à ses moyens;

(E) stretch your arm no further than your

sleeve will reach, stretch your legs according to your coverlet

si on lui en donne un pouce, il en prendra

grand comme le bras (1690)

il a tendance à abuser; (E) give a clown your

finger and he'll take your whole hand

tendre le bras (1640)

(cf. allonger le bras)

tendre les bras (17)

1. (vers qqn) demander secours; (E) to ask for help

2. (à qqn) faire bon accueil; (E) to welcome tomber dans les bras de l'orfèvre (1955)

(cf. être dans les bras de Morphée)

tomber sur qqn à bras raccourcis (1690)

(cf. rompre BRAS et jambes à qqn)

vivre de ses bras

exercer un métier manuel; (E) to make a

living as a manual worker

\section{CERVEAU}

avoir des chambres/ places vides dans le cerveau (1690)

avoir l'esprit dérangé; (E) to have ulcers in the brain, to have a geranium in one's cranium, to be off one's head/ out of one's head/ queer in the head/ soft in the head, to have rocks in one's head, to be bakeheaded, to be out of one's skull

avoir le cerveau brûlé (17)

avoir des idées extravagantes; (E) to have a wild hair up one's ass (US), to have a bug in one's ear (US)

avoir le cerveau fêlé

(cf. avoir des chambres vides dans le cerveau) avoir le cerveau vide (1690)

1. cf. avoir des chambres vides dans le cerveau

2. être peu intelligent; (E) to have one's brain in a leash (US), to be shallow-brained, to have nothing between one's ears, to have more hair than wit, to be fat/ soft in the head, to have a hole in the head (US), to be empty-/ hammer-/ thick-/ wooden-headed, to be dead from the neck up, to be softnosed, to have a thick skull

c'est un cerveau

il est très intelligent; (E) he's a real brainbox cerveau à bourrelets (1640)

1. ignorant; (E) ignoramus, dunce

2. étourdi; (E) airbrain, scatterbrain, shatterbrain, shitterbrain, skitterbrain cerveau brûlé (17)

individu extravagant, excessif; (E) hothead

cerveau creux (1640)

individu fantasque; (E) eccentric, whimsical person

cerveau (mal) timbré (1640)

fou; (E) lunatic

cerveaux enfroqués $(1640)$

moines, religieux; (E) monks, priests

lavage de cerveau (20)

contraintes physiques et psychiques destinées à faire changer qqn d'opinion; (E) brainwash(ing), head-fuck (US)

s'alambiquer le cerveau (1690) réfléchir intensément, cogiter; (E) to beat/ cudgel/ rack one's brain, to bust one's skull

se coiffer le cerveau (17) perdre la raison à force de boire; (E) to go out of one's mind through drinking

se creuser le cerveau (19)

(cf. s'alambiquer le cerveau)

\section{CERVELLE}

avoir du plomb dans la cervelle

(cf. avoir la tête sur les ÉPAULES 2)

avoir la cervelle à l'envers

1. être un peu dérangé; (E) to be a bit weak in the head, not to be quite right in one's head, to have been dropped on the head when one was young

2. être troublé à l'extrême, avoir les idées embrouillées; (E) to have one's brain in a whirl, to have fireworks on the brain, not to know whether one is standing one one's head or heels, to be muddle-headed

avoir la cervelle aux talons (17)

être distrait, étourdi; (E) to be a scatterbrain, to, be featherbrained/feather-headed, to have no head 
avoir la cervelle démontée (1690)

(cf. avoir la cervelle à l'envers 1)

avoir la cervelle en écharpe (1640)

(cf. avoir la cervelle à l'envers 1)

avoir la cervelle qui fait de la chaise longue (1953)

n'avoir pas/ plus les idées très nettes; (E) to have one's head in the clouds

avoir une cervelle d'oiseau

n'être pas très malin; (E) to be a bird-brain

(US), to have the brains of a canary/ a ninny-goat

avoir une cervelle de lièvre

avoir une mauvaise mémoire; (E) to have a

head like a sieve/ no head

belle tête, mais de cervelle point (17)

l'esprit est loin de répondre à l'aspect

extérieur; (E) more guts than brains, more

hair than wit

cervelle à double rebras (17)

imbécile, sot; (E) arse-hole, dozey-arsed

bastard, assface, asshole (US), beetle-brain,

birdbrain, cock-brain, dickbrain, pea-brain, rattlebrain, shuttle-brain, shit-for-brains, dough-face, pudding-face, shit-face, airhead, beanhead, beef-head, beetle-head, blockhead, bonehead, butthead, chuckle-head, cluckhead, clunkhead, conehead, craphead, dead head, dickhead, dough-head, fat head, flat head, fuckhead, jar-head, knucklehead, leatherhead, mallet-head, meat-head, melon-head, mollyhead, moonhead, muddlehead, mullethead, mush head, mutton-head, noddy-head, numbhead, pin-head, piss-head, poophead, pothead, potato-head, pumpkinhead, punkinhead, saphead, sawdust-head, shuttlehead, thick head, wooden head

cervelle bien timbrée (1640)

homme de bon jugement; (E) man of sound judgement

dessécher la cervelle

incommoder fortement (en parlant de chaleur); (E) to feel the heat

estropié de la cervelle (169P)

1. cf. cerveau mal timbré

2. cf. cervelle à double rebras

être en cervelle (1640)

être inquiet, tourmenté; (E) to have clinkers in one's bum, to have one's head full of bees, to have one's nerves on edge, to have butterflies in one's stomach, to have stomach ulcers

faire bouillir la cervelle

(cf. dessécher la cervelle) homme de cervelle (1640)

homme d'esprit, habile homme; (E) nice wit, clever fellow

l'encens gâte plus de cervelles que la poudre n'en fait sauter (1748)

l'homme est souvent victime de sa vanité;

(E) man often falls a victim to his vanity

le cœur bien assis, la cervelle bien assise (17) courageux et sensé à la fois; (E) both brave and sensible

mettre qqn en cervelle (1690) causer de l'inquiétude/ du tourment à qqn ; (E) to cause s.o. to worry

rompre la cervelle à qqn fatiguer qqn par des paroles; (E) to make s.o.'s head split, to talk s.o.'s head off

se brûler la cervelle (19) se suicider; (E) to blow one's brains out

se creuser la cervelle (18) (cf. s'alambiquer le cerveau)

se faire sauter la cervelle (19)

1. cf. se brûler la cervelle

2. se masturber; (E) to finger oneself (f), to finger-fuck (f), to play at stink-finger (f), to fist-fuck, to fuck one's fist, to bring down/ off by hand, to take oneself in hand (US)

se ficher qqch dans la cervelle (18) s'imaginer, se faire des idées; (E) to get ideas into one's head

se mettre la cervelle à l'envers (20)

se faire du souci, se tracasser; (E) to get one's bowels in a uproar, (US), to fret one's guts, to bother one's head (about sthg), to eat one's heart out, to flutter/ fret one's kidneys, to get stomach ulcers

CHAIR

amoureux de carême, qui n'ose toucher la chair (1640)

amant froid ou impuissant; (E) frigid or impotent lover

avoir la chair de poule (19)

1. avoir froid; (E) to have gooseflesh

2. frémir de peur; (E) to have gooseflesh

avoir la chair fraîche

avoir un beau teint; (E) to have a rosy complexion

bonne pièce de chair (1690) gros benêt, lourdaud; (E) all brawn and no brains

chair à canon (18)

soldats; (E) cannon fodder

courtier en chair humaine (1640) proxénète; (E) ass-peddler (US), buttockbroker, flesh-broker/ peddler 
donner la chair de poule (19) causer une grande frayeur; (E) to make one's flesh crawl/ creep

en chair et en os (1515) en personne; (E) in the flesh, in flesh and blood

entre cuir et chair (1690)

en soi-même, secrètement; (E) in the secret of one's heart, under the skin

entre la chair et la chemise (cf. ci-dessus)

entre la chair et la chemise il faut cacher le bien que l'on fait (La Fontaine, 1666)

(cf. en matière d'aumône il faut fermer la BOUCHE et ouvrir le cœur)

être bien en chair (1690) être bien enveloppé(e), potelé(e); (E) to be fleshy

être de chair (et d'os) avoir des faiblesses humaines; (E) to be of the flesh

être encore en chair et en os (1690) être encore plein de vie; (E) to be still going strong

fils de boucher, qui aime tâter la chair (1640) homme ardent, sensuel; (E) lustful fellow

il a plus de chair que de pain il a plus de santé que d'argent; (E) his health is better than his wealth

il n'y a point de belle chair près des os une personne maigre n'est jamais belle; (E) a skinny person is never pretty

ils sont de chair et d'os comme nous (17) les religieux pèchent comme n'importe qui; (E) monks and nuns sin just like anybody jeune chair et vieux poisson (1640) une fille jeune est plus agréable qu'une vieille; (E) a young girl is more pleasurable than an old maid

la chair de sa chair sa progéniture; (E) his own flesh and blood

la chair est faible (Matthieu, 26, 41) il est facile de céder à la tentation; (E) the flesh is weak

la chair lui démange (1640)

1. il a des ardeurs amoureuses; (E) he'd screw a woman's back legs off 2. il cherche la correction; (E) he's asking for it

l'esprit est prompt, mais la chair est faible paroles du Christ à ses apôtres au Jardin des Oliviers; (E) the spirit is willing but the flesh is weak

manger de la chair crue (16) pratiquer l'acte sexuel (f); (E) to go star- gazing on one's back, to have/ take a turn on one's back, to belly-bump, to nail two bellies together, to get a wet bottom, to do/ have a bottom-wetter, to do a/ the buttock jig (US), to play at itch-buttocks, to lie feet uppermost, to make feet for children's shoes, to have a taste of the gut-stick, to get hilt and hair, to lift the heels (US), to pray with knees upwards, to break a leg, to get one's leg lifted, to wriggle navels, to play at couple-yournavels, to stare at the ceiling over a man's shoulder

maquignon de chair humaine (1640)

(cf. courtier de chair humaine)

mettre chair vive en chair vive (16) pratiquer l'acte sexuel (m); (E) to polish one's arse on the top sheet, to screw the arse off a woman, to get some ass (US), to make the beast with two backs, to belly-bump, to do the bone dance, to jump on a woman's bones, to do a buttock jig (US), to play at itch-buttocks, to make feet for children's shoes, to tip the middle finger, to flesh, to have a bit of the gut-stick, to get one's hair cut, to give (some) head (US), to lay the hip (US), to get/ lay/ lift/ throw a/ one's leg over, to play at lift leg, to wriggle navels, to play at couple-your-navels, to shake a skin-coat, to stab in the thigh

mortifier sa chair (13) s'infliger des pénitences; (E) to mortify one's body/ the flesh

œuvre de chair acte sexuel; (E) carnal knowledge

œuvres de la chair passions physiques; (E) physical passions péché de chair est trop commun (1498) (cf. la chair est faible)

péché de la chair péché d'impureté; (E) sin of the flesh

pester entre cuir et chair (17) pester intérieurement; (E) to grumble between one's teeth

plaisirs de la chair (cf. œuvres de la chair)

rire entre cuir et chair (1752)

(cf. rire dans sa barbe)

sa chair lui est plus près que sa chemise (1640) son intérêt prime tout; (E) his own interest comes first

vendeur de chair humaine (17) (cf. courtier de chair humaine)

\section{CHEVEU}

à un cheveu de/ près (18)

de justesse; tout près; (E) within a hair of, 
by/ within a hair's breadth, by a nose, by the skin of one's teeth, by/ within a whisker aller se faire couper les cheveux (1864) aller au bordel; (E) to go to the brothel avoir la tête qui dépasse des cheveux (20) être chauve; (E) to be as bald as an egg avoir les cheveux en broussaille (1872) être mal peigné; (E) to have tousled hair avoir mal aux cheveux (1867) subir les effets d'un abus de boisson; (E) to have a head/ a bad head/ a big head/ a Dutchman's head/ a sore head/ a thick head, to have a mouth like (the bottom of) a bird's/ parrot's cage, to have a mouth like the inside of a Turkish wrestler's jockstrap, to feel as if a cat has kittened in one's mouth, to have a tongue like the bottom of a parrot's cage

avoir un cheveu pour qqn (1867)

être follement épris de qqn; (E) to have eyes for s.o., to be swept off one's feet by s.o., to be head over heels about s.o., to have s.o. under one's skin

avoir un cheveu sur la langue (20) zézayer; (E) to be a mushmouth (US)

c'est la barbe et les cheveux! (1910) (cf. barbe)

c'est la sagesse qui lui a fait perdre/ tomber les cheveux

se dit ironiquement d'un chauve à la moralité suspecte; (E) said ironically of a bald man of dubious morals

chercher des cheveux sur des œufs (20) 1. faire des difficultés pour un rien; (E) to make a fuss about nothing 2. chercher noise à qqn; (E) to pick on s.o. cheveu

1. ténuité, justesse (17); (E) tenuity, narrowness

2. ennui, difficulté (1866); (E) snag, hitch

3. sentiment amoureux (1867); (E) infatuation

comme un cheveu dans/ sur la soupe (1898) mal à propos, inopportun; (E) like a dog on a putting green

couper les cheveux en quatre (19) faire de vaines subtilités; (E) to divide a hair, to split hairs

couper un cheveu en quatre (18) (cf. ci-dessus)

en cheveux (15) sans couvre-chef; (E) hatless

faire dresser les cheveux sur la tête faire horreur; (E) to make one's hair curl/ one's hair stand on end, to be hair-raising fendre un cheveu en deux/ quatre (1690)

(cf. couper les cheveux en quatre)

il a de beaux cheveux (1872)

il a mauvaise mine; (E) he looks ill

il faut saisir l'occasion par les cheveux (16) il faut user de diligence; (E) opportunities are hard to seize

il s'en faut (de l'épaisseur) d'un cheveu (18) c'est un rien trop juste; (E) it's only a hair's breadth short

il y a un cheveu (1867)

il y a une difficulté/ un problème; (E) there's a fly in the ointment

les lunettes et les cheveux gris sont des quittances de l'amour (1821)

la vieillesse sonne le glas de la galanterie (E) old age puts an end to love affairs

ne croître que par les cheveux et par les ongles rester de petite taille; (E) to remain short of stature

ne pas toucher à un cheveu de qqn ne faire aucun mal à qqn; (E) not to lay a finger on s.o.

ne tenir qu'à un cheveu (17) dépendre de très peu de chose; (E) to hang by a thread

ne tenir que par un cheveu résister tant bien que mal; (E) to hang on by the eyebrows/ the eyelashes/ the skin of one's teeth

on ne peut pas peigner un diable sans cheveux on ne peut faire payer qqn qui ne possède rien; (E) s.o. insolvent cannot be made to pay

partager un cheveu (1690)

(cf. couper les cheveux en quatre)

passer la main dans les cheveux à qqn

(cf. tâter le biceps à qqn)

prendre qqn aux cheveux

réprimander qqn; (E) to chew s.o.'s ass out (US), to chew s.o.'s ears off, to clip/ pin s.o.'s ears back, to give s.o. an earful, to give s.o. the elbow, to give s.o. one in the eye, to put s.o.'s eye in a sling, to comb s.o.'s hairl head, to curl s.o.'s hair, to eat s.o.'s head off, to give s.o. a good (old) jaw, to jaw s.o., to give s.o. a rap over the knuckles, to rap s.o. over the knuckles, to give s.o. a mouthful, to jump / walk down s.o.'s throat, to give s.o. (a lick with) the rough side of one's tongue, to give s.o. tongue-pie, to tongue-pad s.o.

rougir jusqu'à la racine des cheveux être extrêmement confus/ honteux; (E) to get/ have the cheek-ache, to flush up to the ears, to blush to the roots of one's hair 
s'arracher les cheveux (19) être au désespoir; (E) to tear one's hair saisir l'occasion par les cheveux (16) faire preuve d'opportunisme; (E) to snatch at the opportunity

se faire des cheveux (blancs) (19)

(cf. se mettre la cervelle à l'envers)

se prendre/ tirer aux cheveux (avec qqn) (17) se quereller, se battre; (E) to tear each other's eyes/ hair

tenir la fortune par les cheveux (1640) avoir la fortune à sa portée; (E) to have fortune within one's grasp

tiré par les cheveux (17) exagéré, forcé; (E) far-fetched

tous les événements ne tiennent qu'à un cheveu (Napoléon, 18)

(cf. le nez de Cléopâtre)

trouver un cheveu à qqch (1867)

trouver un inconvénient à qqch; (E) to find sthg amiss with

trouver un cheveu dans le potage (20)

$$
\text { (cf. ci-dessus) }
$$

un cheveu même a son ombre tout a son importance; (E) there is no hair so small but has its shadow

virage en épingle à cheveux (1906) tournant à $180^{\circ}$ ou presque; (E) hair-pin bend

voilà le cheveu! (1867)

voilà le problème!; (E) there's the rub!

vouloir prendre un homme ras par les cheveux (1606)

tenter l'impossible; (E) to run one's head against a (brick) wall/ a millstone

\section{CHEVILLE}

avoir les chevilles gonflées/ qui enflent (20) être prétentieux, se croire important; (E) to think one has got the lights of Piccadilly Circus shining out of one's arse-hole, to think the sun shines out of one's arse(-hole), to be stiff-arsed, to have a big/ swelled/ swollen head, to have a swelling in the head, to suffer from swelled head, to be big-/swellheaded, to be high-/ toffee-nosed

faire compter les chevilles à qqn (1640) faire attendre qqn longtemps; (E) to leave s.o. to cool his heels

ne pas aller/ arriver à la cheville de qqn (18) être très inférieur à qqn; (E) not to be named in the same breath with s.o.

se donner des coups de pied dans les chevilles (20)

faire son propre éloge, se vanter; (E) to pat oneself on the back, to give oneself a pat on the back, to cock a chest like a half-pay admiral

CIL

avoir les cils cassés (1957)

tomber de sommeil; (E) to have a wink in one's eyes, to have one's eyes drag straws

en un cil d'œil (16)

rapidement, vite fait; (E) in the bat/ twinkling of an eye, hand over fist, in a flick of the wrist

jeter un cil (1977)

1. jeter un regard (à, sur); (E) to cock an eye, to clap eyes on, to have an eyeful

2. lancer une oillade (à qqn); (E) to give

(s.o.) the eye, to make eyes (at s.o.), to eye (s.o.) up

ne pas bouger/ remuer un cil rester absolument immobile; (E) not to move an eyelid

plier les cils

(cf. être dans les bras de Morphée)

CGEUR

à cour failli (1640)

de mauvais gré; (E) with a heavy heart

à cœur joie (17) pleinement; (E) to one's heart content

à coeur ouvert (1640) avec franchise; (E) with open heart, heart to heart, open-heartedly

à cœur vaillant rien d'impossible (1508)

les courageux arrivent à surmonter tous les obstacles; (E) nothing is impossible to a willing heart

à contrecour (1579)

(cf. à cœur failli)

accroche-cour (1872)

mèche de cheveux aplatie en crochet sur la tempe; (E) heartbreaker

aller droit au cour (17)

émouvoir, toucher; (E) to touch one's/ s.o.'s heart

amant de cour (19)

celui qui ne paie pas la prostituée; (E) fancy man (of a prostitute)

amour vainc tout sauf coeur de félon (13)

l'amour ne peut rien contre la perfidie;

(E) love is powerless against treachery

apprendre par cour (13)

apprendre de mémoire; (E) to learn by heart

au fond du cour

au plus profond de soi; (E) in one's heart of hearts

avoir le cour de (14)

s'appliquer; (E) to have at heart, to have 
one's heart set on

avoir du cour au ventre (15)

être courageux, avoir du cran; (E) to have (lots of) backbone, to have (plenty of) guts, to have one's heart in the right place, to be lion-hearted, to be high-stomached

avoir du poil au cour (1836) (cf. ci-dessus)

avoir le cour à la bouche (1842)

(cf. bouche)

avoir du/le cour à l'ouvrage (1791) avoir beaucoup d'ardeur; (E) to put one's back into it, to have one's heart in one's work avoir le cour au bord des lèvres (19) avoir envie de vomir; (E) to feel sick avoir le cour au métier (1640) prendre plaisir à ce que l'on fait; (E) to love one's job

avoir le coeur barbouillé

(cf. avoir le CEEUR au bord des lèvres)

avoir le cour bien accroché (20)

1. cf. avoir du poil au CEUR

2. avoir bon estomac; (E) to have one's mouth paved, to have a cast-iron/ a strong stomach

avoir le cour dans les talons

(cf. avoir chaud au cul)

avoir le cœur en bon lieu (1640)

(cf. avoir du poil au CEUR)

avoir le coeur gros

1. être en colère $(1690) ;(E)$ to be red-assed

(US), to have a monkey on one's back, to have one's back up, to be on one's ear (US), to have one's eyes starting out of one's head, to get/ tie one's face into a knot, to be/ get on one's hind legs, to be in a bad skin 2. avoir du chagrin (1842); (E) to be sad/ sick at heart, to have one's heart full/ heavy, to be heavy-hearted

avoir le cœur haut et la fortune basse (1690) refuser de petits emplois alors qu'on est dans le besoin; (E) to refuse petty jobs though in need

avoir le coeur lourd (20)

(cf. avoir le cœur gros 2)

avoir le cour serré (17)

1. cf. avoir le cœur gros 2

2. être ému, bouleversé; (E) to have one's

heart in one's mouth, to have a lump in one's throat

avoir le cœur sur la main (1779)

1. être bon, généreux; (E) to be openhanded, to have a heart of gold, to be a kindhearted sort
2. être franc, ouvert; to be open-hearted avoir le cour sur les lèvres

1. cf. avoir le cœur à la BOUCHE (1690)

2. cf. avoir le cour serré 2 (18)

3. cf. avoir le CEUR au bord des lèvres (19) avoir mal au coeur (17)

(cf. avoir le CEUR au bord des lèvres)

avoir qqch sur le cour (17)

avoir du ressentiment, ressasser qqch; (E) to have sthg sticking in one's gullet

avoir trop de cour

être trop bon, trop sensible; (E) to be (too)

soft-/ tender-hearted

avoir un cour d'amadou (19)

tomber facilement amoureux; (E) to fall in

love very easily

avoir un cour d'artichaut (1867)

être inconstant en amour; (E) to be a fickle

lover

avoir un cour de citrouille (1842)

1. être apathique, manquer d'énergie; (E) to

lack stamina, to be a sluggard

2. être peu courageux, être lâche; (E) to be a yellow-belly, to be yellow-bellied, to have no

blood in one's veins, to have cold feet, to have no guts, to be chicken-hearted/-livered, to be lily-livered

avoir un coeur de lion

(cf. avoir du CEUR au ventre)

avoir un cœur d'or (19)

(cf. avoir le CEEUR sur la main)

avoir un serrement de cour (17)

être ému; (E) to feel a tug at one's heart strings

bon cour d'homme (1690)

1. homme bon et généreux; (E) kind-hearted sort, great-hearted man

2. homme franc et sincère; $(\mathrm{E})$ open-hearted man

bouche en cour au sage, cour en bouche au fou (1557)

(cf. bouche)

bourreau des cours (20) séducteur invétéré; (E) heartbreaker (US), heart-throb

briser le cour (18)

causer de la peine; (E) to break/ rend one's heart, to cut one to the heart, to make one's heart ache, to be heartrending

cela fait lever le cour (1640)

(cf. cela me revient à la bouche)

cela réchauffe le cour (1640)

cela réconforte, redonne du courage; (E) it

does one's heart good 
cet homme a bon cœur, il ne rend rien (1640) c'est un horrible avare; (E) he's a mingyarsed bastard, he's a skinflint coeur

1. affectivité, amour (12); (E) affectivity, love

2. volonté (14); (E) will

3. courage (1080); (E) courage

4. intuition (1190); (E) intuition

cœur blessé ne peut aider (1557)

la tristesse mène à l'inaction; (E) grief leads to apathy

cœur de femme est tôt mué (14)

la femme est volage; (E) women are fickle cœur de pierre (1690)

homme dur et sans pitié; (E) heart of stone, man of no heart, heartless fellow

cœur étroit n'est jamais au large

l'avare n'est jamais généreux; (E) a miser is never generous

cœur fendu (1864)

(cf. bouche d'en bas)

cœur pensif ne sait où il va (14)

l'amoureux est toujours distrait; (E) lovers are always absent-minded

cour qui soupire n'a pas ce qu'il désire (1616)

les soupirs sont preuve d'insatisfaction;

(E) sighs are a sign of frustration

connaître qqn par cœur (17)

connaitre qqn très bien; (E) to know the

length of s.o.'s foot

contre fortune bon cœur (1749)

(cf. faire contre mauvaise fortune bon cœur)

coup au cour (20)

vive émotion; (E) shock, thrill

coup de cour pour qqch/ qqn

attirance vive et spontanée; (E) liking/ love at first sight

d'un coeur léger

sans réfléchir, allègrement; (E) with a light heart, light-heartedly

dans les belles paroles le cœur ne parle point (1547)

(cf. il dit cela de la BOUCHE, mais le cœur n'y touche)

de bon/ grand cour (1842)

avec plaisir, très volontiers; (E) heartily, whole-heartedly

de gaieté de cour

1. cf. de bon cœur (1579)

2. d'initiative, sans raison (1690); (E) of one's free will

de l'abondance du cour la bouche parle

(Matthieu, 12, 34; 1690)

(cf. bouche) de tout cour (17)

sincèrement, sans réserve; (E) from the bottom of one's heart, with heart and soul

décharger son cour se confier; (E) to make a clean breast of it, to get it off one's chest, to unburden one's heart

déchirer le cour (18) (cf. briser le cœur)

dîner par cœur (17)

se passer de manger; (E) to fill the mouth with empty spoons

dire ce qu'on a sur le coeur (1508)

(cf. décharger son cœur)

donner du cœur (au ventre) à qqn (16) encourager, inciter qqn à agir; (E) to put some guts into s.o., to put some stomach into s.o.

donner son cœur à qqn (17) donner son amour à qqn; (E) to give/ lose one's heart to s.o.

du fond du cour (17) (cf. de tout cœur)

en avoir gros sur le cœur (19) (cf. avoir qqch sur le cœur)

en avoir le coeur net (17) arriver à savoir à quoi s'en tenir; (E) to get to the bottom of it

en matière d'aumône, il faut fermer la bouche et ouvrir le cour

(cf. bouche)

en petit ventre, gros cœur (16)

la vaillance dépasse les appétits matériels;

(E) bravery tops bodily needs

enfoncer un couteau dans le cœur à qqn (18) (cf. briser le cœur à qqn)

être de (tout) coeur avec qqn (19) marquer sa sympathie à qqn; (E) to be in sympathy with s.o.

être sans cour (17) n'avoir aucune pitié; (E) to have plenty of guts but no bowels, to have no heart, to be heartless

faire chaud au cour (qqch) réconforter; (E) to do one's heart good, to rejoice the heart

faire contre mauvaise fortune bon cour (19) ne pas se laisser abattre par les revers; (E) to keep one's chin up, to take it on the chin, to put a brave/ good face on it, to keep a stiff upper lip

faire la bouche en cour (cf. bouche)

faire le joli cour (1810) chercher à plaire aux femmes; (E) to put on airs and graces, to talk mush to women 
faire qqch à contrecœur (16) faire qqch de mauvais gré; (E) to do sthg with a heavy heart

faire revenir le cour (1640) réjouir; (E) to do one's heart good, to make one's heart glad, to rejoice one's heart

faire soulever le cour (17) causer du dégoût, donner la nausée; (E) to make one's gorge rise, to make one's heart turn up, to turn one's stomach

fendre le cour (à qqn) (18) (cf. briser le cœur)

froid aux mains, chaud au cour des mains froides seraient le signe d'un tempérament amoureux; (E) a cold hand and a warm heart

gagner le cour de qqn (1640) obtenir l'affection de qqn; (E) to win s.o.'s heart

haut les cours! (20) courage!; (E) chins up! keep a good heart!

homme de cour (cf. bon cœur d'homme)

il dit cela de la bouche, mais le cour n'y est pas (cf. bouche)

il le dit des lèvres, mais le cœur n'y est pas (cf. ci-dessus)

il n'y a que la main d'un ami qui arrache l'épine du cœur (18)

l'amitié est la grande consolatrice;

(E) friendship is the great comforter

il ne faut pas tant baiser son ami sur la bouche que le cour lui fasse mal (1640) (cf. bouche)

il semble qu'on lui arrache le cour du ventre (1640)

se dit d'un avare auquel on essaie d'emprunter de l'argent; (E) said of a miser when trying to borrow money from him

il sent son cour (1640)

1. cf. avoir du CEEUR au ventre

2. cf. avoir qqch sur le cœur

jeter du cour sur le carreau (1640)

(cf. rendre tripes et BOYAUX)

joli cour (1863)

homme efféminé; (E) pap-mouth (US), pantywaist (US)

joli comme un cour (18)

charmant, mignon; (E) as pretty as a picture

l'esprit est toujours la dupe du cœur (La

Rochefoucauld, 1665)

l'homme est victime de ses sentiments;

(E) man is a victim of his feelings

l'oreille est le chemin du cœur (17) c'est par la parole qu'on éveille les senti- ments; (E) words will stir feelings

la langue du sage est dans son cour, le cour du sot est dans sa bouche

(cf. BOUCHE en cœur au sage...)

la main du coeur (1640)

la main gauche; (E) the left hand

la rage au cour (19)

plein de colère; $(\mathrm{E})$ raging

le chef-d'œuvre de Dieu, c'est le cour d'une

mère

rien ne surpasse le cœur maternel; (E) a mother's heart is God's masterpiece

le cœur a ses raisons que la raison ne connait pas (Pascal, 1670)

la foi en Dieu ne vient pas de la raison;

(E) the heart has its reasons of which reason knows nothing

le cour bien assis, la cervelle bien assise (17) (cf. cervelle)

le cœur fait l'œuvre, non pas les grands jours la valeur d'une vie est faite d'un long courage, non d'héroïsme passager;

(E) unfailing courage, not short-lived heroism, makes the value of life

le cœur garde le corps et le mène où bon lui semble (13)

(cf. on n'est pas maître de son cœur)

le coeur lui bat (1640)

il est inquiet, il a peur; (E) he has his heart in his boots

le cœur lui devient foie il perd courage; (E) he's losing heart

le cour me bondit (1640)

(cf. cela me revient à la bouche)

le coeur me crève (1640)

1. j'ai de la peine; (E) it cuts me to the heart, it goes to my heart, it makes my heart ache

2. je suis plein de ressentiment; (E) it rankles in my heart

le cour me saigne (1640)

je regrette amèrement; (E) I am smitten with remorse

le cœur n'y est pas (20)

cela manque de conviction; (E) my heart isn't in it

le cri du cour (20)

l'expression spontanée de ce que l'on pense; (E) «cri du cœur»

les grandes pensées viennent du cour (Vauve-

nargues, 1746)

à la force de l'intelligence il faut aussi la vivacité des sentiments; (E) the mind needs support from the soul

les sages ont la bouche dans le cour, les fous le cœur dans la bouche (19) 
(cf. BOUCHE en cœur au sage...)

loin des yeux, loin du coeur (1330)

l'absence engendre l'oubli; (E) far from eye, far from heart

main de velours, cour de beurre; main

d'ouvrage, cour de courage

à ses mains on connaît l'homme; (E) man is

known by his hands

manger par cour (17)

(cf. dîner par cœur)

mauvais cœur et bon estomac (1842)

devise des égoïstes; (E) the motto of selfish people

mauvaise tête, mais bon cœur

personne d'un caractère difficile, mais d'une grande bonté; (E) a bad temper but a warm heart

mettre (le) coeur sur (le) carreau (1633)

(cf. rendre tripes et BOYAUX)

mettre du baume au cour (18) consoler, soulager; (E) to pour balm into/ upon a wounded heart

mettre du/ le coeur au ventre à qqn (1574)

(cf. donner du cœur à qqn)

n'avoir pas le coeur à

n'être pas disposé à, n'avoir pas envie de;

(E) not to find it in one's heart to, not to

have the heart to

ne pas porter qqn dans son cour (20)

détester qqn; (E) to hate s.o.'s guts, not to

(be able to) stomach s.o.

ne rien garder sur le coeur (1640)

1. cf. avoir le cœur à la BOUCHE

2. cf. décharger son cour

3. n'être pas rancunier; (E) to have no resentment

nul n'est vilain si le cœur ne lui meurt les hommes sans courage sont seuls méprisables; (E) only cowards are despicable

on a beau prêcher qui n'a cœur de ne rien faire on exhorte inutilement un paresseux ou un lâche; (E) it's useless to lecture a lazybones or a coward

on dit bien quand le cour conduit l'esprit (1744)

(cf. les grandes pensées viennent du cœur)

on n'est pas maître de son cour (Marivaux, 1723)

les passions dominent l'homme; (E) passions govern man

ouvrir son cœur (à qqn) (17)

révéler ses pensées intimes; (E) to unbosom oneself (to s.o.)

parler à cœur ouvert (1640)

(cf. avoir le cœur à la BOUCHE) parler à cour ouvert avec qqn (1605)

s'entretenir franchement; (E) to have a

heart-to-heart talk with s.o.

parler cour à cœur

(cf. ci-dessus)

parler d'abondance de coeur

s'exprimer spontanément; (E) to speak unprepared

parler le coeur dans la main (1690)

(cf. avoir le cœur à la BOUCHE)

perdre cœur (1640)

perdre courage; (E) to lose heart

porter qqn dans son cœur (20)

avoir beaucoup d'affection pour qqn; (E) to be very fond of s.o.

prendre qqch à cœur (1640)

1. s'offenser de qqch; (E) to take offence at sthg

2. faire grand cas de qqch; (E) to get one's heart on, to take to heart

remettre du cœur au ventre à qqn (16)

rendre courage à qqn; (E) top put fresh/ new heart into s.o.

rester sur le cour (17)

1. cf. avoir qqch sur le cœur

2. ne pas digérer; (E) to lie heavy on one's

stomach, to have got a stomach on one's chest

revenir sur le cour (1640)

1. cf. faire soulever le cœur

2. cf. rester sur le cœur

s'en donner à cour joie (1680)

aller jusqu'à l'assouvissement; (E) to indulge oneself to one's heart content, to have the run of one's teeth

savoir par cœur (17)

savoir de mémoire; (E) to know by heart

se parler cour à cour

(cf. parler à cœur ouvert avec qqn)

se ronger le coeur

se consumer de chagrin, de passion; (E) to

break one's heart over

serrer le cour (1640)

affliger, émouvoir; (E) to make one's heart

leap into one's mouth

serrer qqn sur son cour

étreindre qqn; (E) to clasp/ press s.o. to

one's breastl heart

si le coeur vous en dit (1640)

si vous en avez envie; (E) if you feel like it

sonder les reins et les cours

pénétrer les pensées les plus intimes; (E) to

sound the inmost recesses of the heart

soulever le cour (1640)

(cf. faire soulever le cœur) 
tant que le cour me battra dans le ventre aussi longtemps que je vivrai; (E) so long as I live

tenir à cour (19)/ au cour (17) (cf. prendre qqch à cœur 2)

tenir son cour (1640) conserver sa colère, sa rancune; (E) to keep one's anger, one's resentment

tirer du coeur (1640)

(cf. rendre tripes et BOYAUX)

trouver le chemin du cœur de qqn parvenir à émouvoir qqn, à plaire à qqn; (E) to find one's way into s.o.'s heart un cœur chaud vaut mieux que des lettres de noblesse

l'amour vaut plus qu'un titre; (E) kind hearts are more than coronets

une chaumière et un cour (1835) amour simple et naïf; (E) love in a cottage

votre cour est dans le ventre d'un veau! (1640) réponse d'une fille à un homme qui l'appelle 'mon cœur'; (E) a girl's retort to a man who calls her 'my heart'

vouloir manger le coeur de qqn vouer une haine implacable à qqn; (E) to hate s.o.'s guts

y aller de bon cour/ de tout son cour (19) faire preuve d'ardeur, d'enthousiasme; (E) to put one's back/ guts/ heart into it

COL

allonger le col à qqn (1640) pendre qqn; (E) to neck s.o.

cela lui rompt le col (1640) cela le ruine complètement; (E) that ruins him completely

donner le moine par le col (1640)

(cf. allonger le col à qqn)

il vaut mieux allonger le bras que le col (1640) (cf. bras)

s'en mettre plein le col (1906)

1. cf. s'arroser les amygdales

2. cf. se caler les amygdales

s'enfiler qqch/ un coup dans le col (1916) (cf. ci-dessus)

se casser le $\operatorname{col}(1640)$

(cf. se casser le cou)

se hausser / pousser du col (1867)

(cf. se donner des coups de pied dans les CHEVILLES)

\section{CORPS}

à corps perdu (1580)

1. désespérément, impétueusement; (E) neck or nothing

2. en entier; (E) neck and crop/ heels à son corps défendant (1613) malgré soi, contre sa volonté; (E) under duress, under protest

aller du corps (1640)

déféquer; (E) to air the behind (US), to load off/ weight off one's behind, to blow the bowels (US), to clear one's bowels, to squeeze the diaphragm (US)

avoir l'âme chevillée au corps être robuste, solide; (E) to have a robust health

avoir le corps tout moulu (1640)

(cf. avoir les bras rompus)

avoir le diable au corps (13)

1. s'activer constamment; (E) to be always

on the go

2. être tourmentant; (E) to be full of devilment

c'est le plus beau corps nu (1640)

il est cocu (jeu de mots: cornu); (E) he's a buck's face, he's head-marked

contrainte par corps (13) saisie de la personne (pour dette); (E) imprisonment for debt

corps à corps (1900) combat rapproché, lutte; (E) hand-to-hand fight

corps et âme entièrement, sans réserve; (E) with body/ heart and soul

corps vide, âme désolée; et bien repu, âme consolée (1568)

manger réconforte; (E) eating is comforting

donner d'une épée dans le corps (1640) frapper de coups d'épée; (E) to put s.o. to the sword

drôle de corps individu bizarre; (E) queer fellow elle a bu à la bouteille, le bouchon lui est demeuré dans le corps (1640) elle est enceinte; (E) she sprained her ankle, she has more in her belly than ever came through her mouth, she is full in the belly, she has got a belly-bumper/ belly-buster, she's belly-up, she's high-bellied, she's heavy-footed, she's broken-kneed/ broken-legged, she has a two-legged tympany, she's double-ribbed, she's got an Irish toothache

être folle de son corps (1863) se livrer à la débauche; (E) to sleep around (woman)

être sain de corps et d'esprit jouir de toutes ses facultés; (E) to be sound in body and mind 
faire bon marché de son corps (1694) n'attacher aucun prix à la vie, s'exposer sans nécessité; (E) not to value one's skin, to risk one's own skin

faire commerce de son corps (19) se prostituer; (E) to hawk one's arse, to peddle ass (US), to flat-back (US), to wag one's bottom, to peddle flesh (US), to sell one's flesh, to peddle hips, to sell the hips (US)

faire corps neuf (1690) rétablir sa santé; $(\mathrm{E})$ to restore one's health

faire folie de son corps (1260)

(cf. être folle de son corps)

faire haut le corps (1640) partir, s'en aller; (E) to ankle along (US), to haul arsel ass, to head off, to turn one's heel and go, to leg it

faire un bouclier de son corps (17) protéger physiquement; (E) to shield (s.o.) with one's body

gagner sa vie à la sueur de son corps (1640) (cf. faire commerce de son corps)

garde du corps (1549) personne chargée de la protection d'autrui; (E) bodyguard

il faudra me passer sur le corps! (17) je ne céderai pas; (E) over my dead body!

il faut entretenir la vigueur du corps pour conserver celle de l'esprit (Vauvenargues, 1746) (cf. une âme saine dans un corps sain) jus de corps d'homme (1948) sperme; (E) marrow

la fatigue du corps est la santé de l'âme (cf. une âme saine dans un corps sain)

le sang me bout dans le corps (1640) cela m'indigne, me rend furieux; (E) it makes my blood boil

les femmes sont plus chastes des oreilles que de tout le reste du corps (Molière, 1663)

la pruderie des femmes n'est qu'apparente; (E) the prudery of women is pretence

les jambes lui rentrent dans le corps (19)

(E) his legs are giving way under him, he's on his last legs

mettre son corps à l'abandon (1640)

(cf. faire commerce de son corps)

mettre son corps en bière (1640)

boire de la bière (jeu de mots: cercueil);

(E) to drink beer

mortifier son corps (13)

(cf. mortifier sa chair)

n'ayez pas peur qu'il fasse tort à son corps! (1640) c'est un amateur de bonne chère; (E) he is fond of good living n'être qu'un en deux corps être étroitement liés, être intimes; (E) to be close as God's curse to a whore's arse/ close as shirt and shitten arse, to be cheek and jowl with, to be finger and thumb with, to be hand in glove with

ne jamais faire folie de son corps (15)

vivre chastement; (E) to live chastely

passer sur le corps à/ de qqn (17)

molester, renverser, piétiner; (E) to ride s.o. down

perdu corps et biens (13) perte du navire et de l'équipage; (E) loss of vessel with all hands

pleurer toutes les larmes de son corps (19) pleurer abondamment; (E) to cry/ weep one's eyes out, to cry/ sob one's heart out, to cry fit to break one's heart

prendre qqn à bras le corps (19) (cf. bras)

prendre l'ombre pour le corps prendre l'apparence pour la réalité; (E) to take appearance for reality

répondre de qqn corps pour corps être personnellement garant de qqn; (E) to be personally answerable for s.o.

saisir qqn à bras-le-corps (19) (cf. bras)

saisir qqn au corps arrêter qqn; (E) to clap/ lay s.o. by the heels

se bien traiter le corps (1640) faire bonne chère; (E) to claw one's toes

se donner corps et âme (19) se dévouer sans compter; (E) to give oneself body and soul to, to put one's heart and soul into, to throw oneself heart and soul into

se donner de qqch à travers le corps (1640) (cf. se caler les amygdales)

se donner de son épée à travers le corps (1640) vendre son épée, pour manger; (E) to sell one's sword to buy food

séparation de corps (1636) suppression de la vie commune entre mari et femme; (E) separation from bed and board

sirop de corps d'homme (1953) (cf. jus de corps d'homme)

tomber sur le corps à qqn

1. cf. rompre BRAS et jambes à qqn

2. médire de qqn, déblatérer qqn; (E) to knock s.o. behind his back (US), to badmouth s.o., to dirty-mouth s.o. (US)

travailler qqn au corps (1931) solliciter qqn de manière pressante; (E) to press s.o. hard 
une âme saine/ un esprit sain dans un corps sain (Juvénal)

la santé physique est une condition importante de la santé de l'esprit; (E) a sound mind in a sound body

\section{CÔTE}

avoir les côtes en long (1863)

(cf. avoir les bras cassés)

chatouiller les côtes à qqn (20)

(cf. rompre BRAS et jambes à qqn)

côte à côte (13)

l'un contre l'autre; (E) cheek by jowl, shoulder to shoulder, side by side

être de la côte de saint Louis (Scarron, 17)

être de descendance royale; (E) to be of royal descent

il est sorti de la côte de Charlemagne/ de Saint

Louis/ du roi Arthur (1640)

il fait le grand seigneur; (E) he's lording it

la peau lui tient aux côtes (1640)

il est d'une extrême maigreur; (E) he is

nothing but a bag of bones, his ribs stick out, you can see his ribs, he is a regular/ a walking skeleton, he is as skinny as a skeleton, he is nothing but skin and bone, he looks like a tooth-drawer

on lui compterait les côtes (1807)

(cf. ci-dessus)

scier les côtes à qqn (19)

(cf. faire la barbe à qqn 6)

se caler les côtes

(cf. se caler les amygdales)

se casser les côtes (19)

(cf. se casser le cul)

se tenir les côtes (1805)

être en proie au fou rire; (E) to have a belly-

laugh (US), to bust a gut laughing (US), to

laugh one's head off, to burst/ hold/ split

one's sides with laughter

serrer les côtes à qqn

contraindre qqn à l'action; (E) to force s.o.

to act

sonder les côtes à qqn (1640)

(cf. rompre BRAS et jambes à qqn)

travailler les côtes à qqn (1867)

1. cf. rompre BRAS et jambes à qqn

2. cf. tomber sur le corps à qqn (2)

tricoter les côtes à qqn (1863)

(cf. rompre BRAS et jambes à qqn)

un trente-six côtes (1640)

individu de très grande taille; (E) long legs

\section{$\mathrm{COU}$}

aller au casse-cou (18)

aller à toute vitesse ; (E) to ride at a break-

neck pace attraper qqn par la peau du cou

saisir qqn par derrière; (E) to catch hold of s.o. by the scruff of his neck

avoir la bride sur le cou (16)

être libre d'agir à sa guise; (E) to have full

liberty

avoir la corde au cou (19)

être dans une situation désespérée; (E) to

have one's ass in a crack (US)/ in a sling

(US)/ on the line, to have one's eye in a sling

avoir le front dans le cou (1867)

(cf. avoir la tête qui dépasse des CHEVEUX)

avoir son genou dans le cou (1867)

(cf. ci-dessus)

casse-cou (1718)

1. endroit dangereux; (E) danger spot

2. individu téméraire; (E) dare-devil

casser le cou (1866)

(cf. se caler les amygdales)

casser le cou à qqn

1. tuer qqn; (E) to knock s.o. on the head

2. causer la perte/ la ruine de qqn; (E) to cut s.o.'s throat

dalle du cou (19)

gosier; (E) gullet

en charger son cou (1690)

porter un lourd fardeau; (E) to carry a heavy burden

être dans la merde jusqu'au cou (20) avoir de gros ennuis; (E) to be up to the eyes/ up to one's neck in trouble

être dans le pétrin jusqu'au cou (1867)

1. cf. être dans la merde jusqu'au cou

2. être dans une misère extrême; (E) to be living from hand to mouth, to be on one's last legs/ on one's ribs

être toujours pendu au cou de qqn (17) être très attaché à qqn; (E) to cling to s.o.

il vaut mieux tendre la main que le cou (1616) (cf. il vaut mieux allonger le BRAS que le col)

je veux avoir le cou coupé si...! (1690)

je gagerais ma vie que...; (E) I'll crook my elbow and wish it may never come straight!, I'll eat my head!

jusqu'au cou (1360)

complètement, au maximum; (E) up to one's ass (US), up to one's/ the chin, up to one's/ the ears, up to the eyes, over head and ears, up to one's neck

laisser la bride sur le cou à qqn (16) n'imposer aucune contrainte à; (E) to allow/ give s.o. a free hand, to let s.o. have his head mettre la corde au cou à qqn (19)

(cf. casser le cou à qqn 2) 
monter le cou à qqn (19)

(cf. faire une barbe à qqn)

nœud du cou (1894)

nuque; (E) nape of the neck

prendre ses jambes à son cou

1. s'enfuir (1740); (E) to bag ass (US), to

bust/ cut ass (out of somewhere) (US), to

$\mathrm{drag} / \mathrm{haul} / \mathrm{shag}$ ass (US), to pull foot, to

show a clean pair of heels, to take to one's

heels, to drop the leg, to lay one's legs on

one's neck/ to the ground, to leg it, to run off as fast as one's legs can carry one, to show a clean pair of legs, to take to one's legs, to do a shin, to shin (off), to skin out, to shake one's toe-rag

2. courir vite (1690); (E) to run split-arse, to run as fast as one's legs can carry one, to pull foot

rompre le cou à qqn (11)

(cf. casser le cou à qqn)

s'arroser la dalle du cou (1876)

(cf. s'arroser les amygdales)

sauter au cou de qqn (1690)

accueillir qqn avec empressement; (E) to fling/ throw one's arms round s.o./ round s.o.'s neck

se casser le cou (16)

tomber, se tuer en tombant; (E) to break one's neck

se jeter au cou de qqn (1644)

(cf. sauter au cou de qqn)

se mettre dans l'eau jusqu'au cou (17)

(cf. se donner corps et âme)

se mettre la corde au cou (1900)

se marier; (E) to put a halter round one's

(own) neck, to put one's neck in the noose, to knit/ tie a knot with the tongue that cannot be undone/ untied with the teeth

se monter le cou (1867)

1. s'exciter; (E) to work oneself up

2. se faire des illusions; (E) to kid oneself

se rompre le cou (1690)

1. cf. se casser le cou

2. se ruiner; (E) to get ruined

serrer le cou à qqn

étrangler qqn; (E) to wring s.o.'s neck tendre le cou

1. s'étirer pour mieux voir; (E) to crane one's neck

2. s'offrir en victime; (E) to give one's beard/

head for the washing

tordre le cou à qqn

(cf. serrer le cou à qqn)

\section{COUDE}

à œil ou nez malade, ne touche que du coude (17)

(cf. il ne faut toucher aux yeux que du COUDE)

avoir les pieds sous la table, les coudes sur la table (1690)

faire ripaille; (E) to drink and revel

avoir mal au coude

(cf. avoir les bras cassés)

coude à coude (17)

(cf. côte à côte)

donner du coude à qqn (1640)

attirer l'attention discrètement; (E) to give s.o. a poke in the ribs

entrer dans la pâte jusqu'aux coudes (17)

(cf. mettre le BRAS jusqu'au coude)

garder sous le coude (1877)

mettre en attente, en réserve; (E) to set aside, to keep in store

hausser le coude (15)

(cf. s'arroser les amygdales)

huile de coude (1877)

(cf. huile de bras)

il ne faut toucher aux yeux que du coude (1640) qui veut guérir ses yeux ne doit rien faire; (E) never rub your eyes but with your elbow il se mangerait plutôt les bras jusqu'au coude (1640)

(cf. bras)

jouer des coudes (19)

1. se frayer un passage dans la foule; (E) to elbow one's way through a crowd

2. s'imposer de force; (E) to muscle in

lâcher le coude à qqn (19)

cesser d'importuner qqn; (E) to get off s.o.'s neck

le mal à l'œil, il faut le panser avec le coude

(1842)

(cf. il ne faut toucher aux yeux que du COUDE)

les mains sous le menton, les coudes sur la table (1690)

au comble du bien-être; (E) snug and comfortable

lever le coude (1754)

(cf. s'arroser les amygdales)

mettre le bras jusqu'au coude (cf. bras)

ne pas se moucher du coude (1842)

1. cf. avoir les chevilles gonflées

2. faire grand genre, mener grand train;

(E) to do things in great style, to do oneself well 
parler du coude (1640)

(cf. donner du coude)

plier le coude (1585)

(cf. s'arroser les amygdales)

pousser qqn du coude (17)

(cf. donner du coude)

prendre sa permission sous son coude (1867)

se passer de permission; (E) to dispense with permission

se fourrer/ se mettre le doigt dans l'œil jusqu'au coude (1867)

se tromper lourdement; (E) to put one's foot

in it, to put one's foot in one's mouth (US)

se serrer les coudes (20)

se montrer solidaires, se soutenir mutuellement; (E) to support one another

sentir le(s) coude(s) à gauche (1867)

1. marcher avec ensemble (mil.); (E) to

touch elbows (mil.)

2. se sentir appuyé, encouragé; (E) to feel supported

\section{COUILLE}

à couilles rabattues (20)

avec vigueur, intensément; (E) vigorously, zestfully

avoir des couilles (au cul) (1790)

(cf. avoir du CEEUR au ventre)

avoir les couilles molles

(cf. avoir chaud au cul 1)

casser les couilles à qqn (19)

(cf. faire la barbe à qqn) couille

1. cf. cheveu 2

2. chose sans valeur (1957); (E) rubbish

3. erreur grossière $(20)$; (E) blunder

couille molle (1847)

(cf. froid-au-cul)

en avoir plein les couilles

(cf. en avoir plein le cul 2)

mes couilles! (1913)

(cf. mon cul!)

ne pas avoir de couilles (1954)

(cf. avoir un cœur de citrouille 2)

se faire des couilles en or (20)

gagner beaucoup d'argent; (E) to make a lot of money

tenir qqn par les couilles (20)

(cf. tenir le pied sur la GORGE à qqn)

\section{CRÂNE}

avoir le crâne étroit

(cf. avoir le cerveau vide)

avoir mal au crâne

(cf. avoir mal aux cheveux)

bourrage de crâne (20)

mensonges, discours oiseux, propagande;
(E) eyewash, lip gloss

bourrer le crâne à qqn (1907)

en faire accroire à qqn; (E) to stuff s.o. up with lies or empty talk

crâne (1787)

fanfaron; (E) swaggerer

crâne de piaf (1915)

(cf. cervelle à double rebras)

enfoncer qqch dans le crâne à qqn (20)

faire comprendre qqch à qqn; (E) to drive

sthg into s.o.'s head

faire son crâne (1867)

faire le fanfaron; (E) to put on airs, to

swagger

faire un crâne (20)

faire une arrestation; (E) to make an arrest

CUISSE

à qui veut jouir d'aile, il lui faut lever la cuisse

(17)

se préparer à l'acte sexuel (jeu de mots:

d'elle); (E) to prepare for intercourse

accoler la cuisse à un homme (17)

l'embrasser sur la cuisse à sa descente de

cheval; (E) to kiss a man on the thigh when dismounting

aller aux cuisses (1953)

(cf. mettre chair vive en chair vive)

avoir la cuisse facile (19)

être de mœurs légères (f); (E) to be gay in

the arsel groin, to have round heels (US), to

be a roundheels (US), to be gay in the legs, to

be loose-legged

avoir la cuisse gaie (1881)

(cf. ci-dessus)

avoir la cuisse héronnière (1690)

avoir la cuisse maigre; (E) to have lean thighs

avoir la cuisse hospitalière (19)

(cf. avoir la cuisse facile)

avoir la cuisse légère (19)

(cf. avoir la cuisse facile)

ça me fait une belle cuisse! (1872)

cela ne m'est d'aucune utilité; (E) it's as

much use as a headache!

couleur cuisse de nymphe émue (19)

rose tendre; (E) rosy (-colored)

Dieu vous bénisse et vous fasse le nez comme

j'ai la cuisse! (19)

souhait facétieux à qui vient d'éternuer;

(E) jocular wish to s.o. who has just been sneezing

jeu de cuisses (15)

acte sexuel; (E) short-arm practice, hunk/ piece of ass, belly-bumping, belly-ride, rubbelly, bone-dance (US), buttock-stirring, face-making, flesh session, hair (-court), two- 
handed put, leg business, legover, lip-service, poking through the whiskers (US)

que l'on m'embrasse la cuisse! (17)

se disait lorsqu'on avait rendu service ou apporté de bonnes nouvelles; (E) used to be said when one had brought good news or done a great service

se croire sorti de la cuisse de Jupiter (20) (cf. avoir les chevilles gonflées)

se dépouiller les cuisses (20) se donner de la peine; (E) to take pains se taper sur les cuisses (20) (cf. se tenir les côtes)

CUL

à (grands) coups de pied dans le cul par la force; (E) forcibly

aller au cul (1906)

1. cf. mettre chair vive en chair vive

2. cf. mettre un serpentin à l'anus

au poil de cul près (1907)

avec grande exactitude; (E) to a hair's

breadth, right on the nose

avoir chaud au cul (19)

1. avoir peur; (E) to have one's arse make

buttons, to be a yellow belly, to have blood like gnat's piss, to have cold feet, to lose one's guts (US), to have one's heart in one's boots/ mouth, to be lily-livered

2. être excitée sexuellement; (E) to be hotassed (US)

avoir des couilles au cul (20)

(cf. avoir du CEEUR au ventre)

avoir du cul (1960)

avoir beaucoup de chance; (E) to raise/ rise (with one's) arse upwards

avoir du poil au cul (19)

(cf. avoir du CEEUR au ventre)

avoir la paille au $\mathrm{cul}$ (19)

être réformé; (E) to be discharged from the service

avoir la rage au $\mathrm{cul} \mathrm{(16)}$

(cf. avoir chaud au cul 2)

avoir la tête dans le cul

(cf. avoir mal aux cheveux)

avoir la trouille au cul (20)

(cf. avoir chaud au cul 1)

avoir la vessie du cul tournée (1894)

être toujours en mauvaise santé; (E) to be always in bad health

avoir la voix dans le cul (18)

être enroué; (E) to have a frog in one's throat

avoir le cul bordé de nouilles (1977)

(cf. avoir du cul) avoir le cul chaud (1752)

(cf. avoir chaud au cul 2)

avoir le cul entre deux chaises/ selles (19)

1. être dans une situation instable; (E) to

have one's ass on the fence

2. être indécis, irrésolu; (E) to hang an arse

avoir le cul sur le visage (1894)

avoir une mine florissante; (E) to be hale

and hearty

avoir le cul sur selle

être toujours assis (à ne rien faire); (E) to

just sit on one's backside all day

avoir le cul terreux (1640)

être riche en terres; (E) to be a rich landed

proprietor

avoir le cul verni (1914)

(cf. avoir du cul)

avoir le feu au cul

1. cf. avoir chaud au cul 2 (1536)

2. être pressé, se hâter; (E) to be in a hurry, to be pushed for time

avoir le trou du cul derrière les dents (1953) avoir mauvaise haleine; (E) to have foul breath

avoir les dents qui prennent racine dans le trou du cul (1953)

(cf. ci-dessus)

avoir qqch dans la tête et pas au cul (17)

être buté, entêté; (E) to be headstrong/ pigheaded

avoir qqn au/ dans le cul (1808)

éprouver de l'antipathie pour qqn, mépriser qqn; (E) to hate s.o.s guts, to be fed up to the back teeth with s.o.

baiser le cul à qqn (1694)

flatter qqn bassement; (E) to lick s.o.'s arse, to kiss/ lick s.o.'s ass (US), to asslick s.o.

(US), to brown-nose s.o. (US)

baiser le cul de la vieille (1718)

ne pas marquer de points dans certains jeux;

(E) to fail to score in certain games

baisez-moi au cul, la bouche est malade (1640) (cf. bouche)

bas de cul (1640), bas-du-cul (1828)

individu de petite taille; (E) short-arse, all

body and no legs, short-legged fellow, hop-o'my thumb, Tom Thumb

botter le cul à qqn (19)

donner des coups de pied au derrière à qqn;

(E) to kick s.o.'s arse, to boot/ kick s.o. in the ass (US), to kick s.o. up the backside, to sink the boot into s.o.'s backside, to kick s.o.'s

bottom, to toe s.o.'s behind

bouffer le cul (1948)

(cf. se mettre une fausse barbe) 
bout de cul (1867)

(cf. bas de cul)

brûler le cul à qqn

1. cf. casser le cou à qqn 2 (1789)

2. dépasser qqn à la marche (1894); (E) to overtake s.o.

c'est à se taper le cul par terre! (20)

c'est franchement hilarant; (E) it's a regular scream!

ça lui pend au cul! (19)

il n'y échappera pas; (E) he's got it coming to him!

ça vaut mieux qu'un coup de pied au cul! c'est un moindre mal; (E) it's better than a kick up the arse, it's better than a poke/ slap in the belly/ than a slap in the eye with a wet fish/ with a lettuce, it's better than a dig in the eye with a blunt stick!

casser le cul à qqn (20)

(cf. faire la barbe à qqn 6)

cause à mon $\mathrm{cul}$, ma bouche est malade! (17) (cf. baisez-moi au cul, la BOUCHE est malade!)

coller au cul de qqn (20)

1. suivre qqn de très près; $(\mathrm{E})$ to be right on s.o.'s ass (US), to dog s.o.'s footsteps, to be/ tread on s.o.'s heels, to follow close/ fast on s.o.'s heels, to trail at s.o.'s heels, to breathe down s.o.'s neck

2. harceler, importuner qqn; (E) to be (always) on s.o.'s ass (US)/ back/ neck

coûter la peau du $\mathrm{cul}(20)$ coûter très cher; (E) to cost an arm and a leg cul

1. cf. cervelle à double rebras

2. cf. bouche d'en bas (1903)

3. cf. fesse (20)

4. pornographie (1949); (E) pornography,

sex

5. individu méprisable (1863); (E) fart-arse, arsehole, asshole (US), shit-ass (US), fuckface, shit-face, piss-head, shit-head, heel

cul à fauteuil (1861)

académicien; (E) member of an academy

cul béni (19)

bigot; (E) zealous church-goer

cul clos (1640)

le dernier enfant; (E) last child in the family

cul de ménage (1640)

gros derrière; (E) barge-arse, bottle-arse, lard ass, long in the hips, with hips to sell

cul de plomb

1. empoté (1640); (E) butterfingers

2. paresseux (17); (E) heavy-arse, lazybones, lazy-legs
3. bureaucrate (1842); (E) (petty) bureaucrat cul goudronné marin; (E) Jack Tar

cul par-dessus tête (15)

à la renverse; (E) arse over tip/ tits, ass over heels (US), ass over teacups/ tincups (US), head over heels, head over turkey, heels over head

cul-terreux (1867)

1. cf. cervelle à double rebras

2. paysan; (E) redneck (US)

dans le $\mathrm{cul}$, la balayette! (20)

exclamation à l'adresse de qqn qui s'est fait duper; (E) up your arse!

danser du cul (16)

(cf. mettre chair vive en chair vive)

de $c u l$ et de pointe (14)

vaillamment; (E) bravely, gallantly

de mon cul (1749)

nul, sans valeur, méprisable; (E) worthless, dreadful

demeurer entre deux selles, le $c u l$ à terre

1. cf. avoir le cul entre deux chaises (1606)

2. échouer d'un côté comme de l'autre

(1640); (E) to fail both ways

donner de cul et de tête (16)

déployer toute son énergie; (E) to put one's back into it

dormir à l'auberge/ l'enseigne/ l'hôtel du cul tourné

être brouillé avec son conjoint; (E) to be on bad terms with one's wife or husband

elle est très $c u l(20)$

elle est très sensuelle, très désirable; (E) she’s very hot-arsed

en avoir dans le cul (1690) essuyer une grande perte; (E) to suffer a great loss

en avoir plein le $\mathrm{cul}(19)$

1. cf. avoir les bras rompus

2. être excédé, lassé; (E) to have (had) a/ one's bellyful/ a skinful, to be fed up/ sick to the (back) teeth

en avoir ras le cul (20) (cf. ci-dessus)

en rester/ tomber sur le cul (20)

(cf. demeurer bouche bée)

enlever le cul à qqn (1867)

(cf. botter le cul à qqn)

et mon cul, c'est du poulet? (20)

formule de refus catégorique; (E) my (left)

foot!, your nose up my arse!

être à $c u l$

1. être à bout de ressources, ruiné (1640);

(E) not to have a sixpence to scratch one's 
arse with, to be on one's ass (US)/ back/ bones, to have one's back to the wall, to be on one's ear (US), to have one's hair grow through one's hood, to be down at heels/ down to the (knuckle-)bone, to be on one's last legs/ on one's ribs

2. ne savoir plus que dire ou que faire (1842); (E) to be at a loss

être assis entre deux chaises, le $c u l$ à terre (cf. demeurer entre deux selles, le cul à terre) être chargé à cul (1867)

(cf. avoir le feu au cul 2)

être comme cul et chemise (1878)

(cf. n'être qu'un en deux corps)

faire boutique de son cul (20)

(cf. faire commerce de son corps)

faire $c u l$ bas (1640)

(cf. faire commerce de son corps)

faire $c u l$ de plomb (1640)

(cf. avoir le cul sur selle)

faire du tape-cul

faire du trot assis; (E) to trot close

faire lever le cul à qqn (1640)

obliger qqn à se lever; (E) to have s.o. get up

faire un tour de cul (1861)

(cf. mettre chair vive en chair vive)

faux cul (1910)

hypocrite, homme déloyal, traître;

(E) hypocrite, shifty person, double-crosser

flanquer un/ des coup(s) de pied au cul de qqn (cf. botter le cul à qqn)

foutre son pied au cul de qqn

$$
\text { (cf. ci-dessus) }
$$

froid-au-cul (1640)

poltron; (E) candy-ass (US), jelly-belly, yellowbelly, chicken-hearted fellow, yellow heel (US), lily-liver

frottez votre nez au cul de ces gens-là! (1640) ayez à faire à eux et vous verrez comment ils vous traitent; (E) if you have dealings with such people you'll see how they treat you!

hausser le cul (1640) se lever; (E) to get up

histoires de cul (20) histoires érotiques; (E) sex talk, smutty jokes

il a vu son cul en se levant (1640)

il est de mauvaise humeur; (E) he's in a bad skin

il est furieux du cul quand il a la foire (1640)

c'est un poltron, un lâche; (E) he's a yellowbelly, he has cold feet

il est pris au cul et aux chausses (1640) il est pris de tous les côtés; (E) he is caught on all sides il jouerait son $c u l$ s'il ne tenait (1640) c'est un incorrigible joueur; (E) he is an irreclaimable gambler

il l'a tiré de mon cul pour le mettre à sa bouche (1640) (cf. bouche)

il me sort du cul (1867) il m'est insupportable, il m'exaspère; (E) he gives me the bellyache, he comes out of my ears, he gives me a pain in the neck, he gets on my nerves

il n'a que le cul (1640)

il est dans le plus complet dénuement;

(E) he is on his last legs

il s'est levé le cul le premier (1640) (cf. il a vu son cul en se levant)

il y a des coups de pied au cul qui se perdent!

(20)

certaines personnes sont exaspérantes;

(E) he deserves a helping foot!

il y va de cul et de tête, comme une corneille qui abat des noix (1690)

(cf. donner de CUL et de tête)

jouer à $c u l$ contre pointe (1640)

(cf. manger de la chair crue)

jouer à cul levé (1690)

(cf. ci-dessus)

jouer du cul (16)

(cf. mettre chair vive en chair vive)

jusqu'à la Saint-trou-du-cul (1977) jamais; (E) never

l'avoir dans le cul (20)

1. s'être fait avoir, être dupe; (E) to be done in the eye

2. manquer de chance, de réussite; (E) to have shit-ass luck (US)

la tête a emporté le cul (1690) le plus fort a vaincu le plus faible; (E) the stronger has defeated the weaker

laide comme un cul (1640)

(cf. sa BOUCHE dit à ses oreilles que son menton touche son nez)

le $c u l$ lui démange (1864) (cf. avoir chaud au cul 2)

le $c u l$ lui fait lappe lappe/ tif taf (1640) (cf. avoir chaud au cul 1)

lèche-cul (19) vil flatteur; (E) arse-crawler/ -creeper/ -kisser/ licker, ass-kisser/ -licker/ sucker/ -wipe (US), kiss-/ suck-ass (US), back-scratcher, footlicker, brown-nose(r) (US), brown-tongue

lécher le cul à qqn (19)

(cf. baiser le cul à qqn)

lever le cul (1611)

(cf. faire haut le corps) 
mettre le cul en haut (1640) tomber vers l'avant; (E) to fall arse over tip/ ass over heels (US)/ head over heels/ heels over head

mettre qqn au cul de qqn faire suivre qqn, lancer qqn à la poursuite de qqn; (E) to send s.o. after s.o.

mettre qqch/ qqn au trou de son cul (1640) faire peu de cas de qqch, traiter qqn avec mépris; (E) to cock the nose at, to turn up one's nose at, to kick s.o. in the teeth mettre qqn à cul (19)

1. cf. brûler le cul à qqn

2. forcer qqn à abandonner; (E) to force s.o. to give up

mon cul! (19)

expression de refus catégorique; (E) my arse!, my foot!

montrer le cul (1690)

1. cf. prendre ses jambes à son COU 1

2. cf. baisser les bras

n'être qu'un cul et une chemise (1640)

(cf. n'être qu'un en deux corps)

on lui boucherait le $c u l$ avec un grain de millet (17)

il a très peur; (E) his arse is making buttons, he has cold feet, he is losing his guts (US)

noir comme dans le trou du cul d'un nègre très sombre; (E) as black as in the inside of a cow

on se saurait péter plus haut que son cul (1640) on ne peut faire au-delà de son pouvoir; (E) one cannot go beyond one's power

parle à mon $c u l$, ma tête est malade! (cf. baisez-moi au cul, la BOUCHE est malade)

pas plus que de beurre au cul (19) aucunement, rien; (E) as much as one can put in one's eye, a footless stocking without a leg

peigne-cul (1790)

1. cf. cul 2

2. nullité; (E) nonentity

péter plus haut que son $\mathrm{cul}$ (1656)

1. cf. ne pas se moucher du coude

2. vivre au-dessus de ses moyens; (E) to live beyond one's means

pince-cul

1. bal; (E) ball, dance

2. dancing de basse classe; (E) low-class dancing-hall

pisser au cul de qqn (20)

(cf. mettre qqn au trou de son cul)

prendre son $c u l$ pour ses chausses (17)

(cf. se fourrer le doigt dans l'œil jusqu'au
COUDE)

quand il a qqch à la tête, il ne l'a pas au cul (1640)

c'est un entêté, un obstiné; (E) he's a pig-

headed fellow

quel cul! (19)

quel imbécile!; (E) what a dickhead!

rage de cul passe le mal de dents (15)

(cf. rage d'amour est pire que mal de dents)

recevoir la pelle au $\mathrm{cul}(15)$

être licencié, renvoyé; (E) to be thrown out on one's ear, to get the elbow, to be slung out on hands and feet/ on hands and knees, to get kicked out neck and crop

rester (assis) le cul par terre

(cf. demeurer les bras croisés)

ridé comme le cul d'une vieille (1894)

marqué par l'âge; (E) all shrivelled up by age

rire comme un cul (1867)

rire jaune, se forcer à sourire; (E) to grin on the other side of one's face, to laugh on the wrong side of one's face, to laugh out of the other side of one's face, to laugh on the wrong side of one's mouth

sauter aux yeux comme un coup de pied au $\mathrm{cul}$ (20)

être l'évidence même; (E) to hit one in the eye, to leap to the eye, to be as plain as the nose on one's face, to stick out like a sore thumb

scier le cul à qqn (1914)

(cf. faire la barbe à qqn 6)

se casser/ se crever le cul (20)

travailler dur, s'exténuer; (E) to tear/ work one's arse off, to break/ bust one's ass (US), to break one's back, to put one's back into it, to piss/ sweat blood, to bust a gut (US), to slave/ sweat one's guts out, to get/ take the finger out, to work one's finger to the bone, to work one's head off, to keep one's nose to the grindstone

se donner des coups de pieds au $c u l$ se faire des reproches à soi-même; (E) to reproach oneself

se donner du talon dans le cul (1739)

(cf. se donner des coups de pied dans les CHEVILLES)

se geler le $\mathrm{cul}$

(cf. battre le tambour avec les dents)

se gratter le cul (19) hésiter, tergiverser; (E) to sit on one's hands (US)

se magner le cul (1907)

se hâter; (E) to shake the lead out of one's arse, to get the lead out of one's ass (US), to 
shift ass (US), to get/ pull/ take one's finger(s) out, to put some guts into it, to shake/ show (US) a leg, to break one's neck se mettre qqch au cul

(cf. mettre qqch au trou de son cul) se peler le $\mathrm{cul}$

(cf. se casser le cul)

se taper le $c u l$ par terre (1880)/ au plafond (1930)

(cf. se tenir les côtes)

se tenir par le cul comme les hannetons (17) pratiquer l'adultère, l'inceste; (E) to commit adultery, incest

se torcher le cul de qqch (1867)

(cf. mettre qqch au trou de son cul)

sortir du cul (1867)

importuner, exaspérer; (E) to give one the

bellyache/ a pain in the neck, to get on one's nerves

tape-cul, tapecul

1. trot assis; (E) bumping trot

2. véhicule inconfortable, mal suspendu; (E) bone-shaker

tenir qqn au cul et aux chausses (1612)

1. cf. saisir qqn au corps

2. cf. coller au cul de qqn 1

tirer au cul (1833)

renâcler à la besogne, se défiler; (E) to drag one's ass (US/ bottom/ heels (US), to swing the leg

tirer le cul en arrière (1640)

refuser ou feindre de faire qqch; (E) to refuse or pretend to do sthg

tomber $c u l$ par-dessus tête (1640)

(cf. mettre le cul en haut)

tomber le cul par terre

(cf. demeurer bouche bée)

tomber sur le cul

(cf. ci-dessus)

tomber sur le $\mathrm{cul}$ et se faire une bosse au ventre (1864)

tomber enceinte; (E) to take it in the belly, to break a leg

torche-cul

1. journal médiocre (1694); (E) gutter paper

2. papier toilette (20); (E) loo paper tortiller du $\mathrm{cul}$

1. boiter, se déhancher (18); (E) to limp

2. danser (1912); (E) to shake a leg/ a toe touche à ton cul! (20)

occupe-toi de tes affaires!; (E) keep your fucking nose to yourself

trou du cul (19)

(cf. cul) trois pouces et le cul tout de suite (cf. bas de cul)

tu peux te le foutre/ mettre au cul! (1878) je n'en ai rien à faire!; (E) you can shove/ stick/ stuff it up your arse!/ ass! (US)

vieux cul (19) vieille baderne; (E) silly old bugger

DENT

à belles dents, à beaux ongles (1640) avec acharnement; (E) tooth and nail à pain dur, dent aiguë (1568) il faut adapter les moyens à la difficulté; (E) the means must fit the difficulty

agacer les dents provoquer une sensation d'irritation; (E) to set one's teeth on edge

armé jusqu'aux dents (1550) fortement armé; (E) armed to the teeth arracher une dent à qqn (1690) emprunter de l'argent à qqn; (E) to put the arm on s.o. (US), to bite s.o.'s ear, to break s.o.'s shins

avoir de la dent (1867)

se porter comme un charme; (E) to be sound in wind and limb

avoir des mains de laine et des dents de fer être lent au travail mais actif à table; (E) to be slow at work but active when it comes to eating

avoir du poil aux dents (1894)

(cf. avoir du CEUR au ventre)

avoir la bouche pleine de dents

(cf. avoir les dents longues 2)

avoir la dent (1899)

avoir faim; (E) to be belly-pinched, to have a wolf in one's belly, to have belly-wrinkles (US), to have one's guts cry cupboard, to be gutsy, to have a wolf in one's stomach, to have an empty stomach

avoir la dent dure (20) critiquer sévèrement; (E) to be very critical, biting

avoir la mort entre les dents (1640)

être très malade, être mourant; (E) to have one foot in the grave

avoir le trou du cul derrière les dents (1953)

(cf. cul)

avoir les dents aussi longues qu'un gril (1640)

(cf. avoir la dent)

avoir les dents comme des baïonnettes

(cf. avoir la dent)

avoir les dents de derrière/ du fond qui baignent (20)

(cf. avoir sa barbe) 
avoir les dents longues

1. cf. avoir la dent (1548)

2. être très ambitieux (19); (E) to have itchy feet

3. être cupide; (E) to have an itching palm avoir les dents mêlées (1690)

(cf. avoir sa barbe)

avoir les dents qui prennent racine dans le trou du cul (1953)

$$
\text { (cf. cul) }
$$

avoir les dents qui rayent la moquette/ le parquet (20)

(cf. avoir les dents longues 2 )

avoir mal aux dents (1640)

(cf. avoir la dent)

avoir toutes ses dents (19)

être dans la fleur de l'âge; (E) to be in the prime of life

avoir une dent contre qqn (17)

avoir du ressentiment à l'égard de qqn;

(E) to have an aching tooth at s.o.

avoir une dent de lait sur qqn (1606)

avoir de l'inimitié pour qqn dès le jeune âge;

(E) to dislike s.o. from childhood

battre la générale avec les dents (18)

(cf. avoir chaud au cul 1)

battre le tambour avec les dents (1640)

1. cf. avoir chaud au cul 1

2. avoir froid; (E) to have one's teeth chattering

briser le fer aux dents (1640)

entreprendre une chose difficile; (E) to set one's hand to a difficult task, to get one's teeth into sthg

c'est comme si on lui arrachait une dent (1690) (cf. il semble qu'on lui arrache le CEEUR du ventre)

c'est l'histoire de la dent en or! (1842) c'est de la blague!; (E) it's all my eye! casser la croûte sans remuer les dents (20)

(cf. dîner par cœur)

celui qui va en mer sans biscuits revient sans dents

l'imprévoyance expose à des déboires;

(E) improvidence leads to trouble

chamailler des dents (1867)

(cf. se caler les amygdales)

claquer des dents (17)

(cf. battre le tambour avec les dents)

conserver une dent contre qqn (17)

(cf. avoir une dent contre qqn)

creuser sa fosse / sa tombe avec ses dents (1640)

faire des excès de table; (E) to dig one's

grave with one's teeth déchirer qqn à belles dents (1690)

(cf. tomber sur le corps à qqn 2)

dents aiguës et ventre plat trouvent tout bon

qu'est au plat (17)

tout plaît à l'affamé; (E) a hungry man

enjoys any food

dévorer à belles dents (15)

manger de bon appétit; (E) to eat away steadily

donner des noisettes à qui n'a plus de dents

(1690)

offrir un cadeau inutile; (E) to make a

useless present

donner un coup de dent à qqn (1606)

critiquer vivement, reprocher durement;

(E) to give s.o. a smack in the eye, to cast/

fling sthg in s.o.'s facel teeth

du bout des dents (17)

avec répugnance, à regret; (E) squeamishly

être enceinte jusqu'aux dents

(cf. être en cloque jusqu'aux genoux)

être guéri du mal de dents (17)

être mort; (E) to be gone to Rot-His-Bone, to turn up one's toes to the daisies

être sur les dents (1611)

1. cf. en avoir plein le cul 1

2. cf. être en cervelle

faire de l'alchimie avec les dents (1842)

(cf. prendre sur sa bouche)

faire de l'argent avec ses dents (1640)

(cf. ci-dessus)

garder une dent à qqn (1867)

(cf. avoir une dent contre qqn)

grincer des dents (20)

donner des signes de colère; (E) to take

pepper in the nose, to grind one's teeth

grommeler entre ses dents (17)

(cf. pester entre cuir et chair)

il lui vient du bien lorsqu'il n'a plus de dents il est trop tard pour en profiter; (E) he grew rich too late to benefit by it

il n'aura plus (jamais) mal aux dents (1640) (cf. être guéri du mal de dents)

il n'y en a pas pour ma dent creuse (1640) il n'y a pas de quoi me rassasier; (E) there's not enough to fill a bad tooth, there's hardly a toothful

il semble à mon ventre que le diable ait emporté mes dents (1640)

(cf. mes boyaux crient vengeance)

il y aura des pleurs et des grincements de dents

(Matthieu, 8,12)

beaucoup auront à se lamenter; (E) there shall be weeping and gnashing of teeth 
j'ai une de ces dents! (19)

(cf. mes boyaux crient vengeance)

je le ferai malgré lui et malgré ses dents (1690)

il ne me fera pas renoncer; (E) I'll do it in

the teeth of his opposition

je ne suis pas barbier pour me montrer les

dents! (1640)

s'adresse à qqn qui rit avec excès; (E) said to

s.o. who laughs too much

jouer des dents

(cf. se caler les amygdales)

la langue va où la dent fait mal (1842)

on parle volontiers de ses peines; (E) the tongue is ever turning to the aching tooth

les araignées ont fait leur toile sur mes dents (1640)

il y a longtemps que je n'ai rien mangé;

(E) it's a long time I had a bite of food

les dents me démangent (1640)

(cf. mes boyaux crient vengeance)

les dents ne lui font plus mal (1640)

(cf. être guéri du mal de dents)

les gourmands font leur fosse avec leurs dents

(H. Estienne, 1579)

(cf. creuser sa fosse avec ses dents)

manger du bout des dents (17)

(cf. faire la petite bouche 2)

mentir comme un arracheur de dents (1640)

être un grand menteur; (E) to lie in one's teeth/ throat

mentir par la gueule et par les dents (1690) nier tout net; (E) to deny flatly

mettre qqu sur les dents

épuiser qqn (au travail); (E) to work s.o. to exhaustion

montrer les dents (15)

se faire menaçant; (E) to bare/ show one's teeth

montrer les grosses dents à qqn (1690)

1. cf. prendre qqn aux cheveux

2. cf. montrer les dents

n'avoir plus toutes ses dents (19)

être âgé, prendre de l'âge; (E) to be/ get long in the teeth, to be old/ up in the tooth, to be on old toes

n'avoir rien à se mettre sous la dent (17)

1. cf. être à cul 1

2. n'avoir rien à manger; $(\mathrm{E})$ to have nothing to eat

n'en casser/ croquer que d'une dent (17)

ne pas obtenir (tout) ce qu'on voulait;

(E) not to get (all) what one wanted

ne connaître qqn ni des lèvres ni des dents (20)

ne pas connaître du tout (jeu de mots: ni

d'Eve ni d'Adam); (E) not to know s.o. from
Edam

ne pas avoir de quoi se mettre sous la dent

(cf. n'avoir rien à se mettre sous la dent)

ne pas avoir la gale aux dents (18)

manger beaucoup, avec avidité; (E) to eat

voraciously

ne pas desserrer les dents (17)

(cf. demeurer bouche close)

ne pas laisser rouiller ses dents (17)

(cf. ne pas avoir la gale aux dents)

ne pas perdre un coup de dent

ne pas perdre l'appétit; (E) not to miss a mouthful

œil pour œil, dent pour dent (Exode, 21, 24)

formule de représailles; (E) an eye for an eye,

a tooth for a tooth

pan! dans les dents!

(cf. ça lui fera les pieds!)

parler des grosses dents (1640)

(cf. prendre qqn aux cheveux)

parler entre ses dents (13)

marmonner sans vouloir être entendu;

(E) to say sthg between one's teeth

planter une dent (1864)

(cf. mettre chair vive en chair vive)

prendre le mors aux dents

1. s'emporter (1690); (E) to get one's back up

2. s'acharner (1690); (E) to put one's back

into it

3. être très susceptible; $(\mathrm{E})$ to be thin-

skinned/ short-waisted

quand voulez-vous qu'on vous arrache une

dent? (1640)

quand prendrons-nous un verre ensemble?;

(E) when are we having a drink together?

quelque chose à se mettre sous la dent (19)

de quoi manger; (E) a bite of food

quelque chose pour dégraisser les dents (17)

fruit ou friandise après le repas; (E) a fruit

or delicacy after a meal

qui s'obstine à mordre un caillou ne réussit qu'à se briser les dents (1829)

l'obstination vaine n'amène que des ennuis;

(E) vain obstinacy brings nothing but trouble

rage d'amour est pire que mal de dents (15)

rien ne dépasse le mal d'amour; (E) no pain

is worse than lovesickness

rage de cul passe le mal de dents (15)

(cf. ci-dessus)

rage de dents (1867)

fringale; (E) pang of hunger

rester sur les dents

être dans une position fâcheuse; (E) to be in a awkward position 
rigole pendant qu't'as des dents!

(cf. numérote tes os!)

rincer la dent à qqn (1867)

offrir à boire à qqn; (E) to stand s.o. a drink

rire à belles dents/ de toutes ses dents

(cf. se tenir les côtes)

rire du bout des dents (1330)

1. cf. rire comme un cul

2. faire grise mine; (E) to look anything but pleased

se casser les dents (sur qqch) (19) subir un échec, un revers; (E) to fall flat on one's face

se laver les dents (1948)

pratiquer la fellation; (E) to give/ serve head, to tongue

se mettre qqch sous la dent manger un petit qqch; (E) to have a bite of food

seize ans, toutes ses dents et pas de corset (1867) jeune fille dans la fleur de l'âge; (E) girl in the prime of youth

serrer les dents (20)

s'armer de résolution, se préparer à un dur effort; (E) to clench/ set one's teeth

tel a du pain quand il n'a plus de dents (cf. il lui vient du bien lorsqu'il n'a plus de dents)

tirer une dent à qqn (1867)

(cf. arracher une dent à qqn)

tomber sous la dent de qqn (18)

tomber en son pouvoir; (E) to fall into s.o.'s hands

un vieil homme a les dents trop faibles pour

mâcher de la venaison (1559)

(cf. les lunettes et les cheveux gris sont des quittances de l'amour)

vouloir prendre la lune avec les dents (1532)

(cf. vouloir prendre un homme ras par les cheveux)

DERRIÈRE

aller du derrière (1640)

(cf. aller du corps)

avoir le derrière à l'air/ au vent (cf. à poil)

avoir le feu au derrière

(cf. avoir le feu au cul 2)

botter le derrière à qqn

(cf. botter le cul à qqn)

elle peut bien nourrir de la volaille, elle a un

beau derrière (1640)

(cf. cul de ménage)

il fallait qu'il eût des yeux au derrière (1690)

il s'est fait rouler; (E) he has been done in the eye il semble qu'elle l'ait tiré de son derrière (17) elle le méprise au dernier degré; (E) she despises him utterly

il vous en pend autant au derrière (1640) la même chose vous guette; (E) the same threatens you

je m'en torche le derrière! (1640) cela m'est complètement indifférent; (E) it's no skin off my nose!

montrer le derrière (1640)

(cf. montrer le cul)

n'être bons qu'à faire des mouchoirs de derrière (1690)

se dit d'ouvrages médiocres; (E) said of poor literature

on lui a houssé le derrière (1640) on l'a fouetté; (E) he has been flogged

péter plus haut que son derrière (17) (cf. péter plus haut que son cul)

pour une bonne fessée le derrière ne tombe pas le châtiment (physique) fait partie de l'éducation; (E) (physical) punishment is part of education

se donner des talons dans le derrière exprimer une folle joie ou une grande moquerie; (E) to express utter glee or mockery

se lever le derrière le premier

(cf. il a vu son cul en se levant)

se taper le derrière par terre (cf. se tenir les côtes)

se torcher le derrière de qqch

(cf. mettre qqch au trou de son cul)

tomber le derrière par terre

(cf. demeurer bouche bée)

DOIGT

à la mords-moi le doigt (20)

avec désinvolture, sans aucun égard; (E) in a slapdash manner

à un vilain, tends-lui le doigt, il prendra toute la main (1640)

(cf. si on lui en donne un pouce, il en prendra grand comme le BRAS)

au doigt et à l'œil (17)

rigoureusement, strictement; (E) rigorously, strictly

avoir de l'esprit au bout des doigts (1690)

être d'une grande habileté manuelle; (E) to be clever/ good with one's fingers, to have nimble fingers, to be a dab hand at, to be clever/ good with one's hands, to be handy avoir de l'or dans les doigts

(cf. ci-dessus)

avoir des doigts de fée (19)

(cf. ci-dessus) 
avoir des poils au bout des doigts (1866) (cf. avoir les bras cassés)

avoir les doigts crochus

1. cf. aimer la manche plus que le bras

2. être voleur; (E) to have itchy/ sticky fingers; to have fingers made of lime-twigs, to be light-/ sticky-fingered, to have an itching palm

avoir les doigts de pieds en bouquet de violettes/ en éventail (20)

être au comble de la jouissance; (E) to have an orgasm

avoir sur les doigts (17)

se faire réprimander; (E) to get one's arse

kicked, to get the elbow, to get one's face slapped, to get a mouthful, to catch/ get it in the neck, to feel the rough side of s.o.'s tongue, to get tongue-pie

avoir une (belle) bague au doigt (1842)

1. avoir du bien qui rapporte; (E) to have property that brings in nicely

2. avoir une sinécure; (E) to have a cushy job

boire le petit doigt gaillard (1690)

faire la noce entre honnêtes gens; (E) to live it up among decent people

cela se voit au doigt et à l'œil

on ne peut manquer de le voir; (E) you can see it with half an eye, it is staring you in the face, it sticks out like a sore thumb

c'est le doigt de Dieu! (17)

c'est le destin, la fatalité; (E) it's the finger of Fate/ God

connaître qqch sur le bout des doigts (1640)

connaître parfaitement; (E) to have sthg at one's fingertips

connaître qqn sur le bout des doigts (1640)

(cf. connaître qqn par cœur)

croire qu'il n'y a qu'à souffler et remuer les doigts

la critique est aisée; (E) in calm weather everyman's a pilot

croiser les doigts (20)

conjurer le sort; (E) to cross (one's) fingers

doigt (1861), doigt qui n'a pas d'ongle (1640) (cf. boyau)

donner sur les doigts à qqn (1640)

(cf. prendre qqn aux cheveux)

entre l'arbre et l'écorce, il ne faut pas mettre le doigt (1842)

il ne faut pas intervenir dans une discussion délicate; (E) put not thy hand between the bark and the tree

être comme les deux doigts de la main (1640)

(cf. n'être qu'un en deux corps) être de la société du doigt dans l'œeil (1872)

avoir les illusions de la vanité; (E) to pretend to oneself

être montré du doigt (1640)

avoir mauvaise réputation; (E) to be in bad repute

être servi au doigt et à l'œil (1611) ne manquer de rien; (E) to be waited upon hand and foot

faire toucher qqch du doigt à qqn (17) lui montrer de façon tangible; (E) to make s.o. realise sthg

faire toucher une vérité au doigt et à l'œil (1690) (cf. ci-dessus)

filer entre les doigts 1. s'écouler rapidement (argent, etc.); (E) to slip through s.o.'s fingers

2. échapper à qqn; (E) to slip through one's fingers

il a de la poix aux doigts (1640) (cf. aimer plus la manche que le bras)

il a mal au bout du doigt il se croit malade pour un rien; (E) he's got a pain in his little finger, he caught cold by lying in bed barefoot

il ne l'a pas sucé de son doigt cette idée ne lui est pas venue toute seule; (E) he hasn't sucked that out of his fingers

il ne sait rien faire de ses dix doigts (17) c'est un bon à rien; (E) he has never done a hand's turn

je n'en voudrais pas mettre le doigt au feu (16) il n'y a rien de moins sûr; (E) I wouldn't swear to it

je ne voudrais pas seulement lui tendre le petit

doigt (1640)

je ne veux l'aider en aucune façon; (E) I wouldn't lift/ stir a finger (to help him)

jusqu'au bout des doigts(17) entièrement, tout à fait; (E) to the fingertips

l'honneur est le diamant que la vertu porte au doigt (Voltaire, 18)

l'honneur est la richesse de l'homme vertueux; (E) honour without profit is a ring on the finger

le mauvais couteau coupe le doigt et non le bois (1568)

les faux moyens produisent des résultats contraires à ceux qu'on attend; (E) the same knife cuts bread and fingers

le petit doigt en l'air/ levé (20) avec affectation; (E) affectedly

le petit doigt sur la couture du pantalon (1899) avec discipline, sans regimber; (E) with strict discipline, without jibbing 
les cinq doigts de la main ne se ressemblent point

les caractères et les opinions diffèrent autant que les doigts de la main; (E) dispositions and opinions differ as much as the fingers of the hand

les doigts dans le nez (1912) sans effort, avec facilité; (E) with one's eyes shut, with one hand tied behind one's back, with the left hand, hands down, (standing) on one's head, as easy as kiss my arsel eyel hand/ thumb

les doigts d'une main ne s'entresemblent pas (15)

la proximité n'empêche pas la diversité;

(E) proximity does not preclude diversity

les os lui sortent des doigts (1690)

c'est un joueur de dés; (E) he is a dicer

manger ses doigts de qqch (1640)

trouver qqch excellent; (E) to lick one's

fingers of sthg, to lick/ smack one's lips over sthg

marcher au doigt et à l'œil (1819)

obéir sans rechigner; (E) to obey at the lift of a finger, to toe the line

menacer qqn du doigt

agiter le doigt en signe de menace; (E) to

wag one's finger at s.o., to shake one's fist at s.o.

mener au doigt et à l'œil (19)

diriger avec autorité; (E) to lead/ manage with authority

mettre le doigt au bénitier (1861)

(cf. mettre chair vive en chair vive)

mettre le/ son doigt au feu (16)

se déclarer sûr de ce qu'on avance; (E) to take one's oath on it

mettre le doigt dans l'engrenage (20)

se laisser entraîner dans un processus auquel on ne peut plus échapper; (E) to get caught up in the machine

mettre le doigt dessus/ sur (1842)

deviner juste; trouver ce qu'on cherchait;

(E) to lay/ put one's finger on it

mettre le doigt entre l'arbre et l'écorce (17)

prendre un risque; (E) to chance one's arm,

to put one's ass on the line (US), to put one's

hand between the bark and the tree, to stick one's neck out

mon petit doigt me l'a dit! (17)

se dit aux enfants pour leur faire croire qu'on connait la vérité; (E) a little bird told me (so)

montrer qqn au/ du doigt (1690)

désigner qqn à l'opprobre; (E) to point the finger (of scorn) at s.o.

ne mets ton doigt en anneau trop étroit (1672)

il faut craindre un mariage servile; (E) one should beware of a dependent marriage ne pas bouger/ lever/ remuer le petit doigt (19)

1. ne pas faire un geste pour empêcher qqch;

(E) not to lift/ stir a finger

2. ne faire aucun effort, refuser d'agir;

(E) not to lift/ stir a finger

ne rien faire de ses dix doigts(1640)

(cf. avoir les bras cassés)

ne savoir rien faire de ses dix doigts (17)

être un grand incapable; (E) to be a good-

for-nothing

ne toucher que du bout du doigt

traiter avec circonspection, avec ménagement; (E) to handle cautiously, tactfully

obéir au doigt et à l'œil (19)

(cf. marcher au doigt et à l'œil)

on ne saurait toucher au beurre/ manier du

beurre qu'on ne s'en graisse les doigts (17)

à manipuler beaucoup d'argent il en colle toujours un peu aux mains; (E) he that handles pitch shall foul his fingers, he that measures oil shall anoint his fingers

on peut les compter sur les doigts d'une main/ sur ses doigts

il y en a très peu, ils sont peu nombreux;

(E) you can count them on the fingers of one hand

on s'en lècherait les cinq doigts et le pouce

(1894)

c'est franchement délicieux; (E) it's sthg to

lick one's fingers of

onzième doigt (1640)

(cf. boyau)

s'en lécher les quatre doigts et le pouce

(cf. manger ses doigts de qqch)

s'en mordre les doigts (1640)

1. cf. avoir le cœur gros 1

2. regretter amèrement, se repentir; (E) to repend, to rue it

3. manifester de l'impatience; (E) to bite one's nails (with impatience)

savoir qqch sur le bout des doigts (17)

(cf. connaître sur le bout des doigts)

se brûler les doigts avoir des ennuis, tomber en quelque péril; (E) to get one's fingers burnt/ nipped

se cacher derrière son petit doigt

refuser de voir la réalité tout en se dérobant à ses responsabilités; (E) to close one's eyes to reality while eluding one's responsibilities se faire au doigt (1931)

se masturber (f); (E) to finger-fuck 
se faire taper sur les doigts

(cf. avoir sur les doigts)

se fourrer/ se mettre le doigt dans l'œil (jusqu'au coude) (1864)

(cf. coude)

se lécher les doigts de qqch (1640)

(cf. manger ses doigts de qqch)

se manger les doigts (1640)

(cf. avoir le cœur gros 1)

se manger les doigts de qqch (1640)

(cf. manger ses doigts de qqch)

taper sur les doigts de qqn (17)

(cf. prendre qqn aux cheveux)

tirer au doigt mouillé (19)

façon enfantine de régler certains différends par tirage au sort; (E) children's way of settling certain differences by drawing lots

toucher au doigt (1414)/ du doigt (1835)

comprendre clairement; (E) to understand clearly

toucher (du bout) du doigt (1672)

être bien près de; $(\mathrm{E})$ to be close on, not far short of

y mettre le doigt (1878)/ les doigts (1926)

voler qqch; (E) to bone, to lay hands on

y mettre les quatre doigts (et le pouce) (18)

1. se servir salement d'un mets; (E) to take

from a dish with the hand

2. agir avec brutalité, sans délicatesse; (E) to act rudely

DOS

avoir bon dos

1. cf. avoir le bras lourd (1690)

2. pouvoir supporter une contrainte (19);

(E) to be able to take it

3. être l'éternelle victime (19); (E) to be the one who always gets the blame

avoir des yeux dans le dos (20)

être très vigilant; (E) to have all one's eyes about one

avoir les pieds dans le dos (20)

être poursuivi par la police; (E) to have the cops breathing down one's neck

avoir qqn à dos (20)

avoir qqn contre soi; (E) to have an enemy in s.o.

avoir qqn sur le/ son dos (20)

(cf. avoir qqn sur les bras)

bas du dos (19)

postérieur; (E) arse, ass (US), backside, (blind)

cheeks, blind eye, Sunday face, round mouth

battre qqn dos et ventre (1640)

(cf. rompre BRAS et jambes à qqn)

casser du sucre sur le dos de qqn

(cf. tomber sur le corps à qqn 2) coup de poignard dans le dos (19)

perfidie, trahison; (E) perfidy, betrayal

courber le dos

céder, se soumettre; (E) to back down, to

come to heels, to knuckle under

donner du dos (20)

être homosexuel (passif); (E) to be a

(passive) homosexual

donner froid dans le dos

(cf. donner la chair de poule)

dos à dos (17) appuyés l'un contre l'autre; (E) back to back

dos d'azur (1864)

(cf. courtier de chair humaine)

dos fin (1866)

(cf. ci-dessus, jeu de mots: dauphin)

dos vert (1773)

(cf. ci-dessus)

elle se tient mieux sur le dos qu'une chèvre sur

les cornes

c'est une marie-couche-toi-là; (E) she's a

roundheels (US)

en avoir plein le dos (1809)

(cf. en avoir plein le cul 2)

être le dos au mur

être dans une position fâcheuse; (E) to be with one's back to the wall

être mort dans le dos (1828)

(cf. battre le tambour avec les dents 2)

être sur le dos

(cf. en avoir plein le cul 1)

être (toujours) sur le dos de qqn (20)

1. cf. coller au cul de qqn 2

2. surveiller qqn de près; (E) to keep one's eye on s.o., to breathe down s.o.'s neck

faire froid dans le dos

(cf. donner la chair de poule)

faire la bête à deux dos (15)

(cf. mettre chair vive en chair vive; manger de la chair crue)

faire le dos rond

(cf. faire le gros dos 2)

faire le gros dos

1. faire l'important (1690); (E) to put on airs

2. laisser passer le danger (20); (E) to ward off danger

faire pénitence sur le dos de qqn faire supporter le blâme par autrui; (E) to palm off the blame on s.o., to put the blame on s.o.'s shoulders, to let s.o. else shoulder the blame

faire qqch derrière le dos de qqn faire qqn en cachette; (E) to do sthg behind s.o.'s back 
faire qqch quand on a le dos tourné

$$
\text { (cf. ci-dessus) }
$$

faire un enfant dans le dos à qqn (20) tromper/ trahir qqn à son insu; (E) to betray s.o.

filer du dos (20)

(cf. donner du dos)

frotter le dos à qqn (19) (cf. rompre BRAS et jambes à qqn)

haler du dos (1640) (cf. mettre chair vive en chair vive)

il a bon $d o s$, il portera bien tout (1640) il est assez riche pour payer le tout; (E) he has a broad back, he has broad shoulders

il tombe sur le dos et se casse le nez (1842) 1. il est très maladroit; (E) he is a butterfingers

2. il est malchanceux; (E) he has shit-ass luck (US)

l'avoir dans le dos

1. cf. l'avoir dans le cul 2 (17)

2. cf. l'avoir dans le cul 1 (20)

labourer du dos (1894)

(cf. être guéri du mal de dents)

lâcher du $\operatorname{dos}$ (1948)

(cf. donner du dos)

le dos au feu, le ventre à table (1690)

(cf. les mains sous le menton, les COUDES sur la table)

les avoir dans le dos (20)

(cf. avoir les pieds dans le dos)

mal est caché à qui l'on voit le dos le poltron s'expose à des nouvelles attaques; (E) a coward is open to more attacks

manger la laine sur le dos de qqn (1792) dépouiller qqn; (E) to skin s.o.

manger la peau sur le dos à qqn affamer qqn; (E) to starve s.o.

mettre qqch sur le dos de qqn (19)

(cf. faire pénitence sur le dos de qqn)

montrer le dos (1640)

1. cf. montrer le cul

2. cf. baisser les bras

mort dans le dos (16)

homme impuissant; (E) impotent man

n'avoir pas une chemise à mettre sur le dos (1690)

être dénué de tout; (E) not to have a rag to one's back

n'avoir rien à se mettre sur le dos

(cf. ci-dessus)

n'être pas large du dos (1957)

(cf. aimer plus la manche que le bras)

passer la main dans le dos à qqn (19)

(cf. tâter le biceps à qqn) plier le dos

(cf. courber le dos)

prendre du dos (20)

(cf. mettre un serpentin à l'anus)

prendre qqn par la peau du dos

saisir qqn brutalement pour l'expulser;

(E) to take s.o. by the scruff of the neck

prendre (tout) sur son dos (19)

assumer (toute) la responsabilité; (E) to

shoulder (every) responsibility

prêter son dos (19)

(cf. ci-dessus)

qui fait credos charge son dos (1640)

qui donne à crédit se ruine; (E) he who gives credit ruins himself

renvoyer dos à dos (1690)

ne pas trancher en faveur de l'un ou de

l'autre; (E) to leave a dispute unsettled

scier le dos à qqn (18)

(cf. faire la barbe à qqn 6)

se laisser manger la laine sur le dos (1585)

se laisser dépouiller, exploiter; (E) to allow

oneself to be skinned

se laisser tondre la laine sur le dos (1690)

(cf. ci-dessus)

se mettre le dos au mur (20)

s'ôter toute échappatoire; (E) to cut off any

way out

se mettre qqn à dos (20)

se faire un ennemi de qqn; (E) to set s.o.

against oneself

se passer la main dans le dos (19)

(cf. se donner des coups de pied dans les CHEVILLES)

se retirer le dos rond

partir humilié, l'air piteux; (E) to go off with a flea in one's ear/ with one's tail between one's legs

tirer dans le dos de qqn

attaquer qqn de manière déloyale; (E) to

give s.o. a stab in the back

tomber sur le dos de qqn

1. cf. prendre qqn aux cheveux

2. arriver à l'improviste; (E) to burst on s.o.

3. se précipiter sur qqn pour le frapper; (E)

to come down heavily on s.o.

tomber sur le dos et se faire une bosse au ventre (1867)

(cf. tomber sur le CUL et se faire une bosse au ventre)

tondre qqn sur le dos

(cf. manger la laine sur le dos de qqn)

tourner le dos (1640)

1. cf. montrer le cul

2. cf. baisser les bras 
tournez-moi le dos! (1640)

allez-vous-en! allez au diable!; (E) pound salt up your ass!(US), I'll be glad to see your back!, go and shake your ears!, toast your blooming eyebrows!, bag your face! (US), foot!, go and fry your face!, fuck off and give my head peace!, go (away) and boil your head!, leg it!, get off my neck!

\section{ÉPAULE}

avoir la/ sa tête sur les épaules (20)

1. être prudent, circonspect; (E) to be cautious, wary

2. avoir du bon sens, être réaliste; (E) to have one's feet (firmly) on the ground, to have a good head on one's shoulders, to have one's head screwed on (the right way), to be level-headed

baisser les épaules (1640) être très patient; $(E)$ to be very patien changer son fusil d'épaule (1883)

1. changer d'avis, de comportement; (E) to change one's mind, one's behaviour 2. changer ses projets; (E) to change one's plans

chargez, il a de bonnes épaules! (1640)

(cf. il a bon dos, il portera bien tout)

courber les épaules (devant qqn)

(cf. courber le dos)

donner le/ un coup d'épaule à qqn (1640)

(cf. prêter son bras à qqn)

en avoir par-dessus les épaules

1. cf. en avoir plein le cul 2

2. être débordé; (E) to be up to the ears/ the eyes/ one's neck in it, to have one's hands full

épaules en bouteille de Saint-Galmier (20) épaules étroites et tombantes; (E) narrow, drooping shoulders

épaules en porte-manteau (19)

épaules tombantes; (E) drooping shoulders

épaules qui trottent (1902)

les cuisses; (E) the thighs

être sur les épaules de qqn

(cf. être sur les bras de qqn)

faire épaule (1640)

(cf. donner le coup d'épaule)

faire l'épaule rennoise à qqn (20)

battre froid, bouder qqn; (E) to chuck a

shoulder, to give s.o. the cold shoulder

faire qqch par-dessus l'épaule (19)

(cf. à la mords-moi le doigt)

faire toucher les épaules à qqn (20)

(cf. faire la barbe à qqn 1)

frapper sur l'épaule (1640)

1. cf. tâter le biceps à qqn
2. montrer de l'amitié; (E) to show friendship graisser les épaules à qqn (1690)

(cf. rompre BRAS et jambes à qqn)

hausser les épaules (17)

montrer de l'impatience, du dédain, de

l'étonnement; (E) to shrug one's shoulders

il est bien large par les épaules (17)

(cf. aimer plus la manche que le bras)

il faut lever les épaules (1690)

il faut subir en silence; (E) one must endure without a word

loucher de l'épaule (1867)

être bossu; (E) to be hunch-backed

marcher des épaules (17) se pavaner; (E) to strut

mettre qqn dehors par les épaules (17) chasser qqn rudement; (E) to throw s.o. out on his ass (US)/ ear, to give s.o. the (big) elbow, to bundle s.o. out on his head, to throw s.o. out on his neck, to bundle s.o. out neck and heels

montrer les épaules (1640)

(cf. prendre ses jambes à son $\mathrm{COU}$ )

pendant que le bâton va et vient, les épaules se reposent (1842)

il y a des intermissions à toute peine;

(E) there are intermissions to any grief

peser sur les épaules de qqn

(cf. être sur les bras de qqn)

porter qqn sur les épaules

1. cf. avoir qqn sur les bras (1640)

2. avoir pitié de qqn (1690); (E) to take pity on s.o.

prêter l'épaule (1580)

(cf. prêter son bras à qqn)

regarder qqn par-dessus l'épaule (1690)

considérer qqn avec mépris; (E) to look

down on s.o.

rouler les épaules (20)

(cf. marcher des épaules)

tirer saint Martin par l'épaule (1640)

ôter son manteau; (E) to take off one's overcoat

tomber sur les épaules de qqn

(cf. être sur les bras de qqn)

\section{ÉPIDERME}

avoir l'épiderme chatouilleux (1864)

(cf. prendre le mors aux dents 3 )

chatouiller l'épiderme à qqn (19)

(cf. tâter le biceps à qqn)

\section{ESTOMAC}

avoir de l'estomac (1904)

1. cf. avoir du CCEUR au ventre

2. cf. avoir bon dos 1 
3. avoir de l'aplomb; (E) to have a hell of a cheek/ plenty of cheek, not to be short of cheek, to have a brazen face, to be a cool hand, to have a (brass) neck, to have (a hell of) a/ some nerve, to have a skin avoir l'estomac bien accroché

(cf. avoir le cœur bien accroché) avoir l'estomac creux

(cf. avoir la dent)

avoir l'estomac dans les talons (1850)/ les gadins (1898)

(cf. avoir la dent)

avoir petit estomac

avoir peu d'appétit; (E) to have no stomach for one's food

avoir un creux à l'estomac

(cf. avoir la dent)

avoir un estomac d'autruche (1751)

(cf. avoir le cœur bien accroché 2)

avoir un trou à l'estomac

(cf. avoir des boyaux vides)

avoir une éponge dans l'estomac (19)

(cf. avoir le gosier en pente)

avoir une fuite dans l'estomac (1957)

roter; (E) to burp

estomac

1. courage, cran (1460); (E) guts

2. aplomb, assurance (1868); (E) cheek, lip, mouth, neck, nerve

la peau d'un chrétien est bonne pour échauffer l'estomac d'une fille (1640)

le coït guérit bien des femmes; (E) to sleep with a man heals many a girl

le faire à l'estomac (1868)

faire qqch avec aplomb; (E) to bluff, to put it over s.o.

mauvais cœur et bon estomac (1842)

(cf. cœur)

remords d'estomac (1894)

renvoi, rot; (E) belch

rester sur l'estomac

(cf. rester sur le cœur)

s'appliquer un homme sur l'estomac (18)

(cf. manger de la chair crue)

FACE

à face hardie une preuve ne nuit (1607)

l'effronté n'est pas décontenancé par les faits qu'on lui oppose; (E) impudence is not confused by facts

avoir deux faces

être fourbe, hypocrite; (E) to be two faces under one hood, to be double-faced

changer de face (1640)

prendre une autre apparence; (E) to take on another look dire qqch en face à qqn

dire qqch sans détours; (E) to say sthg to s.o.'s facel under s.o.'s very nosel straight from the shoulder

être à deux faces/ à double face (cf. avoir deux faces)

face à face (13067)

(cf. bouche à bouche 1)

face d'abbé (16)

visage rubicond; (E) ruddy face

face d'homme fait/ porte vertu

1. les ouvriers travaillent mieux en présence du maître (1690); (E) workers work better when the master is present

2. la présence d'un homme sert beaucoup à ses affaires (18); (E) a man's presence serves his business

face de carême figure triste et morose; (E) dismal face

face de crabe/ d'œuf/ de rat (20) insultes; (E) dog-face, pig-face, shit-face

faire face (à)

1. affronter, résister (1657); (E) to face up to things, to square one's shoulders

2. pourvoir à (1798); (E) to face

jeter qqch à la face de qqn

(cf. donner un coup de dent à qqn)

la face du Grand Turc (1640)

(cf. bas du dos)

perdre la face (1850)

être humilié, subir un affront; (E) to lose face

regarder qqn (bien) en face

regarder qqn hardiment; (E) to look s.o. full/ squarely/ straight in the eye/ face

sauver la face (19)

garder sa dignité; (E) to save (one's) face

se voiler la face (19)

1. se cacher le visage (en signe de chagrin, de honte, etc.); (E) to put one's hands to one's

face, to hide one's face (in sorrow, in shame, etc.)

2. refuser de voir ses responsabilités; (E) to refuse to see one's responsibilities

\section{FESSE}

avoir chaud aux fesses (1743)

(cf. avoir chaud au cul 1)

avoir du mercure aux fesses

ne pas tenir en place, être agité; (E) to have ants in one's pants

avoir la fesse tondue (1739)

être roué (en parlant d'un séducteur); (E) to be artful (speaking of a seducer)

avoir le feu aux fesses (1958)

(cf. avoir le feu au cul) 
avoir les fesses en goutte d'huile (20) avoir des fesses molles et tombantes; (E) to have flaccid, drooping buttocks avoir une perruque en peau de fesses (1977)

(cf. avoir la tête qui dépasse des CHEVEUX) bas de fesses (1640)

(cf. bas de cul)

botter les fesses à qqn

(cf. botter le cul à qqn)

coûter la peau des fesses (20)

(cf. coûter la peau du CUL)

dauber des fesses (1640)

(cf. manger de la chair crue)

de mes fesses (1905)

(cf. de mon cul)

en avoir dans les fesses (1690)

(cf. en avoir dans le cul)

faire un tour de fesse (1861)

(cf. mettre chair vive en chair vive)

fesse (1881)

la femme comme objet érotique; (E) ass, hair

fesses en goutte d'huile (20)

fesses molles et tombantes; (E) flaccid, drooping buttocks

film de fesse (20)

film pornographique; (E) skin flick

gare tes fesses! (20)

pousse-toi! écarte-toi!; (E) get off/ up your arse!

histoire de fesse

anecdote grivoise; (E) blue joke

il n'y a pas à tortiller des fesses! (1867)

il ne faut pas tergiverser; (E) no shillyshallying!

il y aura de la fesse (20)

des filles seront présentes; (E) there will be plenty of hair

larder les fesses à qqn (1640)

donner des coups d'épée dans le derrière;

(E) to give s.o. sword strokes in the buttocks

les fesses lui font taf taf (1640)

(cf. avoir chaud au cul 1)

magasin de fesses (1867)

lupanar; (E) flesh market (US)

mes fesses! (1900)

(cf. mon cul!)

n'aller que d'une fesse

1. être en difficulté (1611); (E) to be out on

a $\operatorname{limb}$

2. n'être pas en bonne santé (1867); (E) to

be in bad health

n'y aller que d'une fesse

1. montrer peu d'empressement (1611);

(E) to hold back
2. faire qqch sans conviction, sans enthousiasme (1894); (E) to do a half-ass job (US), to go about it half-heartedly

occupe-toi de tes fesses! (20)

(cf. touche à ton cul!)

pain de fesses (1960)

argent de la prostitution; (E) prostitution money

peau de fesses (20)

1. cf. cul 2

2. cf. face de crabe

pince-fesses

(cf. pince-cul)

pincer les fesses (à une femme)

(cf. faire une main tombée)

pique-fesses (20)

infirmière; (E) nurse

poli comme mes fesses (1953)

d'une extrême grossièreté; (E) rude, unmannerly

poser ses fesses

s'asseoir; (E) to bring one's arse to an

anchor, to take a load off one's feet

prendre ses fesses à poignée

(cf. prendre ses jambes à son COU 2)

prendre son nez pour ses fesses (1640)

(cf. se fourrer le doigt dans l'œil jusqu'au

COUDE)

qu'il aille gratter ses fesses au soleil! (1690)

se dit à qqn qui prétend n'avoir rien à faire;

(E) said to s.o. who claims he has nothing to do

rebondi comme les fesses d'un pauvre homme (1640)

très plat; $(\mathrm{E})$ very flat

s'en battre les fesses (1648)

(cf. se torcher le cul de qqch)

se faire mettre dans les fesses (20)

(cf. donner du dos)

se faire labourer les fesses (1640)

(cf. manger de la chair crue)

se magner les fesses (1907)

(cf. se magner le cul)

serrer les fesses (1877)

1. cf. avoir chaud au cul 1

2. être sur ses gardes; (E) to be on one's

guard

3. se tenir coi; (E) to sit tight

tabourer des fesses (1640)

(cf. manger de la chair crue)

tortiller des fesses

1. cf. tortiller du cul 2 (1881)

2. marcher en agitant le derrière (1640);

(E) to walk with the hips, to wiggle one's hips 


\section{FIGURE}

avoir un pied de rouge sur la figure (19) être maquillée à outrance; (E) to wear a lot of make-up

avoir une figure d'enterrement

(cf. faire une longue figure)

avoir une figure de Vendredi Saint (cf. ci-dessus)

avoir une figure longue d'une aune (cf. ci-dessus)

casser la figure à qqn (18)

frapper qqn au visage; (E) to give s.o. a thick ear, to warm the wax of s.o.'s ear, to box/ warm s.o.'s ears, to give s.o. one in the eye, to pay over face and eyes, to punch s.o. in the face, to push/ smash s.o.'s face in, to put a new facel head on s.o., to comb s.o.'s head with a (three-legged) stool, to kick s.o.'s head in, to punch s.o.'s head, to break s.o.'s jaw/ neck, to kick/ knock in s.o.'s teeth

faire bonne figure se montrer à son avantage; (E) to show up to advantage

faire bonne figure à qqn (cf. accueillir qqn à bras ouverts)

faire (une) longue figure avoir l'air triste, abattu; (E) to have a face as long as a fiddle, to have a face like a seaboot/ like a wet week/ like a yard of pumpwater, to make a (sour) face, to pull a long face, to look down in the mouth

faire triste figure

1. cf. faire (une) longue figure

2. être dans une piètre situation; (E) to cut a sorry figure

figure à faire tourner une sauce blanche (1894) visage d'une grande laideur; (E) face-ache, face like the back of a bus, face that would stop a clock

figure de papier mâché (1836) visage pâle et fatigué; (E) face like a scrubbed hammock

jeter qqch à la figure de qqn (17)

(cf. jeter qqch à la face de qqn) se casser la figure

1. cf. se casser le cou (19)

2. cf. se casser les dents (20)

se payer la figure de qqn (19)

(cf. faire la barbe à qqn 4)

FLANC

être sur le flanc (1865)

(cf. en avoir plein le cul 1)

mettre qqn sur le flanc (19)

épuiser qqn; (E) to knock s.o. up, to tire s.o. out prêter le flanc à (1740) donner prise, s'exposer à ; (E) to lay oneself open to

se battre les flancs (1764)

1. cf. se mettre la cervelle à l'envers

2. se donner beaucoup de mal; (E) to make desperate efforts

tire-au-flanc (1887)

1. cf. cul de plomb 2

2. personne qui cherche à échapper aux corvées; (E) malingerer, shirker

tirer au flanc (1881)

chercher à échapper aux corvées; (E) to malinger, to shirk

\section{FOIE}

avoir bon foie

garder son calme, ne pas s'emporter; (E) to have one's brains on ice

avoir des chaleurs au foie (1640)

se mettre en colère; (E) to get one's back up, to have a monkey on one's back, to lose one's hair

avoir les foies (1872)

(cf. avoir chaud au cul 1)

avoir les foies blancs

1. cf. avoir chaud au cul 1 (1813)

2. cf. avoir un cœur de citrouille 2 (1883)

avoir les foies chauds pour qqn (19)

(cf. avoir un cheveu pour qqn)

bouffer les foies à qqn

(cf. rompre BRAS et jambes à qqn)

foie blanc (1840)

1. cf. froid-au-cul

2. cf. faux-cul

j'ai l'os du foie qui me fait mal (20) je ne me sens pas bien (lendemain de fête, faux malaise); (E) I'm feeling seedy

le cœur me devient foie (cf. cœur)

manger les foies à qqn

(cf. rompre BRAS et jambes à qqn)

se ronger les foies

(cf. se mettre la cervelle à l'envers)

vous avez bon foie, Dieu vous sauve la rate!

(1690)

à d'autres, je ne vous crois pas; (E) tell that to the marines!

FRONT

avoir le front dans le cou (1867)

(cf. avoir la tête qui dépasse des CHEVEUX)

avoir le front de (17)

avoir l'audace, l'insolence de; (E) to have the cheek/ facel nerve to

avoir un front d'airain (1690)

(cf. avoir de l'estomac 2) 
courber le front

(cf. courber le dos)

faire front (16)

(cf. faire face 1)

front (17)

audace, hardiesse, insolence; (E) cheek, face, nerve

jolie fille porte sa dot au front

la beauté est une dot suffisante; (E) a girl's pretty face is her fortune

marcher à front découvert

n'avoir rien à dissimuler; (E) to have nothing to hide

marcher le front haut/ levé

ne montrer ni crainte ni honte; (E) to carry one's head high, to walk with one's head high/ in the air

montrer un front serein

ne montrer aucun trouble; (E) to show an unruffled countenance

relever le front

(cf. reprendre cœur)

\section{GENCIVE}

en prendre plein les gencives (20)

1. cf. perdre la face

2. cf. avoir sur les doigts

être sur les gencives (20)

(cf. avoir les bras rompus)

mettre qqch dans les gencives à qqn (19)

1. cf. jeter qqch à la face de qqn

2. cf. prendre qqn aux cheveux

\section{GENOU}

artilleur à genoux (1872)

infirmier militaire; (E) medical orderly

avoir la tête comme un genou

(cf. avoir la tête qui dépasse des CHEVEUX)

avoir les genoux bien graissés (1640)

faire force révérences; (E) to bow and scrape

avoir son genou dans le cou (1867)

(cf. avoir la tête qui dépasse des CHEVEUX)

bijoutier sur le genou (1867)

cordonnier; (E) cobbler

c'est à se mettre à genoux devant! (20)

c'est divinement beau/ bon; (E) it's simply divine!

couper comme le genou de ma grand-mère/

comme un genou (1881)

ne pas couper du tout; (E) to have no edge at all

desserrer/ écarter les genoux (19)

(cf. manger de la chair crue)

embrasser les genoux à qqn (17)

supplier qqn, s'humilier devant qqn; (E) to throw oneself at s.o.'s feet, to go down on one's knees to s.o. être à genoux devant sa patience (1867)

(cf. avoir bon foie)

être chauve comme un genou (1866)

(cf. avoir la tête qui dépasse des CHEVEUX)

être aux genoux de qqn (1782)

1. adorer qqn; (E) to worship s.o.

2. être à la merci de qqn; (E) to be in s.o.'s

fists/ hands, to be under s.o.'s thumb

être en cloque jusqu'aux genoux (19)

être enceinte; (E) to be full/ high in the belly, to have (got) a belly-bumper/ -buster, to be with a bellyful of marrow-pudding, to have a bellyful, to be belly-stretched/ belly-up, to be high-bellied/ heavy-footed/ broken-kneed/

broken-legged, to have a two-legged tympany, to be double-ribbed, to have an Irish toothache

être né sur les genoux d'une duchesse

(cf. être né avec une cuiller d'argent dans la bouche)

être pâle des genoux (1917)

(cf. avoir les bras rompus)

être sur les genoux (1926)

(cf. ci-dessus)

faire du genou à qqn (19)

faire une invitation amoureuse sous la table; (E) to play footy-footy/ footsie/ footsiewootsie/ footums/ kneesies with s.o. (under the table)

genou (1907)

crâne chauve; (E) bald head

genou creux

(cf. cul de plomb 2)

lire dans le livre où l'on tourne les feuillets à genoux (1650)

(cf. manger de la chair crue)

mettre qqn à genoux (14)

obliger qqn à capituler, à renoncer; (E) to

bring s.o. to heels/ to his knees

mousquetaire à genoux (1718)

apothicaire; (E) apothecary

plier les genoux (1690)

(cf. embrasser les genoux de qqn)

rompre l'andouille (1690)/ l'anguille (1640) au genou

1. commettre une action absurde ou impossible; (E) to do sthg absurd or impossible

2. s'y prendre mal pour faire qqch; (E) to make a bad fist at/ of

se jeter aux genoux de qqn

(cf. embrasser les genoux de qqn)

tomber à genoux devant qqch/ qqn

être éperdu d'admiration; (E) to be lost in admiration of sthg/ s.o. 
GLAND

effacer un gland (1931)

(cf. manger de la chair crue)

gland (1864)

1. cf. boyau

2. cf. cul 5

pomper le gland (1864)

(cf. se laver les dents)

quel gland!

(cf. quel cul!)

se taper (sur) le gland (1864)

(cf. se faire sauter la cervelle 2)

va-du-gland (1864)

amateur de plaisir sexuel; (E) ass-man, belly-

bumper, pinch-buttock, lusty-guts, hair-

monger, skin-dog

\section{GLANDE}

avoir les glandes (1976)

1. cf. avoir des chaleurs au foie

2. être déprimé; (E) to have a black dog on one's back, to be cheesed off to the eyebrows, to hang one's head, to be down-/ heavyhearted, to be down in the mouth

donner/ filer/ foutre les glandes à qqn (1976)

1. mettre qqn de mauvaise humeur; (E) to get s.o.'s back up

2. démoraliser qqn; (E) to take the heart out of s.o.

se tirer sur les glandes (20)

(cf. se faire sauter la cervelle 2)

\section{GORGE}

avoir la gorge serrée (19)

(cf. avoir le cœur serré 2)

avoir le couteau sur la gorge (19)

être sous le coup d'une menace; (E) to have the knife on one's throat

avoir un chat dans la gorge (1863)

(cf. avoir la voix dans le cul)

avoir un noud dans la gorge

(cf. avoir le cœur serré 2)

coupe-gorge (17)

endroit dangereux, piège; (E) cut-throat place

couper la gorge à qqn

1. cf. casser le cou à qqn 2 (1640)

2. cf. clore la bouche à qqn (1690)

crier à pleine gorge

hurler de toutes ses forces; (E) to shout at the top of one's voice

être chatouilleux de la gorge (21690)

être pendu; (E) to die with cotton in one's ears, to leave the world with one's ears full of cotton, to bless the world with one's heels, to dance at the sheriff's ball and loll out one's tongue at the company faire des gorges chaudes de qqch (1842) se moquer ouvertement de qqch; (E) to have a good laugh at sthg

faire rendre gorge à qqn (16) obliger qqn à restituer; (E) to force s.o. to hand back

faire rentrer les paroles dans la gorge à qqn (1690) obliger qqn à retirer ses paroles; (E) to make s.o. eat his words

gorge chaude (1640) (cf. va-de-la bouche)

la gorge lui démange (1690) il n'échappera pas à la corde; (E) he will hang

le rendre fait mal à la gorge (1568) il est pénible de remettre l'argent emprunté (jeu de mots: rendre); (E) it's hard to return borrowed money

mentir cent pieds à la gorge (1690)

(cf. mentir comme un arracheur de dents)

mettre le couteau sous (1690)/ sur (1866) la

gorge à qqn

contraindre qqn (par menaces); (E) to force s.o. to do sthg

prendre à la gorge agresser les voies respiratoires; (E) to get right up one's nose, to catch (in) the throat prendre qqn à la gorge

1. cf. mettre le couteau sur la gorge (1690)

2. combattre, faire pression sur qqn (16);

(E) to run counter s.o.

rendre gorge

1. cf. rendre tripes et BOYAUX (16)

2. restituer ce qu'on a pris; (E) to hand back rester en travers de la gorge (19)

(cf. rester sur le cœur 1)

rire à gorge déployée (1585)

(cf. se tenir les côtes)

s'arroser la gorge (18)

(cf. s'arroser les amygdales)

se couper la gorge)

1. s'entretuer, se battre à mort (1640); (E) to fight to death

2. parler étourdiment (1690); (E) to talk through the back of one's neck

tenir le pied sur la gorge à qqn

1. traiter qqn avec rigueur (1640); (E) to treat s.o. harshly

2. avoir l'avantage sur qqn, tenir qqn à sa merci (16); (E) to have s.o. by the short hairs/ in the hollow of one's hand/ on the hip, to have / keep s.o. under one's thumb, to have/ hold s.o. by the toe 
tenir qqn à la gorge

(cf. tenir le pied sur la gorge à qqn 2)

\section{GOSIER}

avoir le gosier en pente (19)

être fort buveur; (E) to be an elbow-bender/ -crooker, to be a guzzle-/ swizzle-guts/ to be a jar-head, to have a spark in one's throat avoir le gosier blindé/ ferré/ pavé (1690) être capable de manger ou de boire très chaud ou très épicé; (E) to have a cast-iron throat

avoir le gosier sec

avoir soif; (E) to have a cobweb in the throat, to have one's tongue hanging out avoir toujours le gosier ouvert (1640) être toujours à crier; (E) always to be shouting

avoir une éponge dans le gosier

(cf. avoir le gosier en pente)

c'est le bon Dieu/ le petit Jésus qui vous descend dans le gosier en culottes de velours! (1894) cette boisson est délicieuse; (E) that drink is simply divine!

crier à plein gosier

(cf. crier à pleine gorge)

grand gosier (1690)

(cf. va-de-la bouche)

la mousse m'est crue au gosier (17)

(cf. les araignées ont fait leur toile sur mes dents)

rire à plein gosier

(cf. se tenir les côtes)

s'humecter/ se rincer le gosier (16)

(cf. s'arroser les amygdales)

\section{GUEULE}

amuse-gueules (20)

menues friandises servies avec l'apéritif;

(E) appetisers

arracher la gueule (1866)

être très épicé; (E) to burn a hole in the stomach

arriver la gueule enfarinée (1656)

afficher une confiance naïve; (E) to be naively optimistic

avoir de la gueule

1. parler fort et sans arrêt; (E) to be a big talker

2. avoir de l'allure, de la classe; (E) to look classy

avoir la gueule de bois (1867)

(cf. avoir mal aux cheveux)

avoir la gueule de l'emploi

avoir le physique qui correspond à la

profession; (E) to look the part avoir la gueule pavée

(cf. avoir le cœur bien accroché 2)

avoir une bonne gueule

avoir un air avenant; (E) to look a nice guy

avoir une grande gueule (1947)

protester violemment; (E) to be big-mouthed

avoir une sale gueule (1942)

1. cf. faire une longue figure

2. avoir un air peu sympathique; (E) to look mean

brûle-gueule

pipe à tuyau très court; (E) nose-warmer

casse-gueule

1. cf. casse-cou

2. cf. tord-boyaux

3. entreprise dangereuse; (E) breakneck undertaking

casser la gueule à qqn (1723)

(cf. casser la figure à qqn)

coller/ foutre la main sur la gueule à qqn

(cf. casser la figure à qqn)

crever la gueule ouverte (1919)

mourir abandonné de tous; (E) to die

forsaken by all

donner un coup de gueule (1891)

1. cf. montrer les grosses dents

2. faire un éclat; (E) to blow off at the

mouth, to shoot off one's mouth

écorcher la gueule

1. être difficile à prononcer; (E) to be a

jawbreaker/ jawbuster/ tongue-twister

2. être très pénible à exprimer (excuses); to

be painful to utter (excuses, etc.)

emporter la gueule (1866)

(cf. arracher la gueule)

en prendre plein la gueule (1883)

1. cf. avoir sur les doigts

2. se faire taper dessus; (E) to get one's face smashed in/ one's face remodelled

être fort en gueule (1624) parler beaucoup et grossièrement; (E) to be loud-/ foul-mouthed

être porté sur la gueule

(cf. être porté sur la bouche)

faire la gueule (1898)

1. cf. faire une longue figure

2. cf. faire une tête longue d'un BRAS

faire la gueule à qqn

1. cf. faire une longue figure

2. cf. faire l'épaule rennoise à qqn

faire une sale gueule (1903)

(cf. faire une longue figure)

faire une gueule d'enterrement avoir une mine triste; (E) to have a face like 
an undertaker

fermer sa gueule (1747)

(cf. demeurer bouche close)

fine gueule (1890)

(cf. fine bouche)

fort en gueule (1656)

individu qui parle beaucoup mais agit peu;

(E) one who talks much but acts little grande gueule (1947)

personne qui a le verbe haut; (E) big-mouth gueule

1. bouche; (E) mouth

2. visage; (E) face

gueule à caler les roues d'un corbillard

(cf. figure à faire tourner une sauce blanche) gueule à coucher dehors avec un billet de logement

(cf. ci-dessus)

gueule d'amour (1928)

séducteur; (E) lady-killer, playboy

gueule d'empeigne (1867)

(cf. figure à faire tourner une sauce blanche) gueule de faire-part (1914)

(cf. faire une gueule d'enterrement) gueule de raie

(cf. face de crabe)

gueule fraîche

(cf. va-de-la-bouche)

gueules cassées (1914-18)

mutilés de guerre; (E) disfigured veterans of

World War I

gueules noires (1945)

mineurs; (E) coal miners

la gueule tue plus que le glaive

(cf. creuser sa fosse avec ses dents)

mentir par la gueule et par les dents

(cf. dent)

rincer la gueule à qqn

(cf. rincer la dent à qqn)

s'en mettre plein la gueule (1931)

(cf. se caler les amygdales)

se bourrer la gueule

(cf. prendre sa barbe)

se casser la gueule (1942)

1. cf. se casser le cou

2. cf. se casser les dents

se faire casser la gueule

(cf. en prendre plein la gueule 2)

se fendre la gueule (17)

(cf. se tenir les côtes)

se foutre de la gueule de qqn

(cf. faire la barbe à qqn 4)

se foutre la gueule par terre

(cf. se casser le cou) se foutre sur la gueule (1907)

(cf. se prendre aux cheveux)

se saouler la gueule (1902)

(cf. prendre une barbe)

ta gueule!

(cf. ta bouche, bébé!)

tu peux crever la gueule ouverte!

tu peux aller au diable!; (E) you can go to hell!

va-de-la-gueule

(cf. fort en gueule)

HANCHE

mettre le poing sur la hanche/ les poings sur les

hanches

prendre une attitude résolue, menaçante;

(E) to stand with one's arms akimbo, to put one's hands on one's hips

JAMBE

avoir de bonnes jambes

être bon marcheur; (E) to be strong in the

leg, to have a good pair of legs, to have good legs

avoir des fourmis dans les jambes (1831)

éprouver des picotements; (E) to have pins and needles in one's legs

avoir des jambes en coton (1867)

flageoler (de faiblesse, de peur); (E) to be trembling at the knees

avoir la jambe tout d'une venue comme la

jambe d'un chien (17)

avoir des jambes très maigres; (E) to have toothpicks

avoir les jambes coupées être frappé de stupeur; (E) to be knocked off one's feet

avoir les jambes en flanelle (20)

(cf. avoir des jambes de coton)

avoir les jambes en manches de veste (19) avoir les jambes arquées; (E) to be bandy-I bow-legged

avoir les jambes en $\mathrm{X}$

avoir les genoux cagneux; (E) to be knockkneed/ baker-legged

avoir les jambes rompues

(cf. avoir les bras rompus)

avoir ses jambes de quinze ans (1690)

être bon marcheur malgré l'âge; (E) to be

still a good walker in spite of age

ça me fait une belle jambe! (1857)

(cf. cela me fait une belle cuisse!)

ça vaut mieux qu'une jambe cassée/ que de se casser une jambe! (1854)

(cf. ça vaut mieux qu'un coup de pied au CUL) 
casser/ couper bras et jambes (19)

$$
\text { (cf. bras) }
$$

cela me fait la jambe belle! (1640)

(cf. cela me fait une belle cuisse)

cela ne me rendra pas la jambe mieux faite! (1690)

(cf. cela me fait une belle cuisse)

chercher sa cinquième jambe

(cf. avoir les bras rompus)

croc-en-jambe (1640)

escroquerie, supercherie; (E) bad turn, fast one

donner le/ un croc-en-jambe à qqn (1690)

jouer un vilain tour à qqn; (E) to shoot s.o. in the eye

être dans les jambes de qqn

constituer un embarras, une gêne; (E) to be

a nuisance to s.o.

être jambe (1933)

(cf. c'est la BARBE et les cheveux 1)

être pâle des jambes (1917)

(cf. avoir les bras rompus)

être vite sur jambes (1975)

avoir la compréhension rapide; (E) to be quick in the uptake

faire des ronds de jambe (20)

exagérer les complaisances; (E) to fawn and cringe

faire jambe de bois (1899)

partir sans payer l'addition; (E) to leave without paying the bill

faire (une) jambe de vin (1640)

boire pour se donner des forces; (E) to drink to revive one's strength

faire la belle/ fine jambe

se pavaner; (E) to strut about

faire qqch par-dessous la jambe (1884)

(cf. à la mords-moi le doigt)

faire un croc-en-jambe à qqn

(cf. donner le croc-en-jambe à qqn)

faire une partie de jambes en l'air (1949)

(cf. manger de la chair crue; mettre chair vive en chair vive)

il a trouvé ses jambes prêtes (1640)

il s'est enfui incontinent; (E) he ran away forthwith

il faut faire le pas selon la jambe

(cf. selon le bras la saignée)

jambe du milieu (1898)

(cf. boyau)

jeter le/ un chat aux jambes de qqn (17)

1. cf. faire pénitence sur le dos de qqn

2. faire obstacle à qqn; (E) to put an obstacle in s.o.'s way jouer de l'épée à deux jambes (1640)

(cf. prendre ses jambes à son COU 1)

jouer des jambes (1867)

(cf. ci-dessus)

jouer qqn par-dessous/ sous la jambe (1671)

l'emporter facilement sur qqn; (E) to get the better of s.o. very easily

la jambe! (1904)

(cf. la barbe!)

la tête et les jambes (1926)

le savoir et les qualités physiques;

(E) learning and physical strength

le lit est l'écharpe de la jambe (1752)

quand on souffre des jambes, il faut garder le lit; (E) with aching legs one should stay in bed

les jambes lui rentrent dans le corps

(cf. corps)

lever la jambe (1860)

1. cf. mettre chair vive en chair vive

2. cf. avoir la cuisse facile

3. danser (le cancan); (E) to sling one's body

I a foot, to shake a leg/ a toe

loucher de la jambe (1867)

(cf. tortiller du cul 1)

mettre la jambe à une femme (1864)

(cf. mettre chair vive en chair vive)

mettre la queue entre les jambes (16)

(cf. ci-dessus)

mon esprit ne va pas si les jambes ne l'agitent

(Montaigne, 1588)

(cf. une âme saine dans un corps sain)

n'aller que d'une jambe

(cf. n'aller que d'une fesse 2)

n'avoir plus de jambes

(cf. avoir les bras rompus)

n'avoir plus ses jambes de vingt ans

(cf. n'avoir plus toutes ses dents)

ne pas s'en aller sur une jambe (1867)

boire un second verre/ une seconde bouteille

avant de partir; (E) to wipe the other eye

partie de jambes en l'air (1949)

(cf. jeu de cuisses)

passer la jambe à qqn (19)

(cf. donner le croc-en-jambe à qqn)

passer la jambe à une femme (1864)

(cf. mettre chair vive en chair vive)

prendre ses jambes à son cou (1640)

(cf. cou)

quand on n'a pas bonne tête/ la tête, il faut avoir

bonnes/ des jambes

qui n'a pas de mémoire doit souvent

multiplier ses courses; (E) little wit in the

head makes much work for the feet, his head will never save his heels 
s'en retourner la queue entre les jambes (1690) (cf. se retirer le dos rond)

s'enfuir à toutes jambes (16)

(cf. prendre ses jambes à son COU 1)

s'il passe par la rue des Ménestriers, on prendra ses jambes pour faire des flûtes (1640) il a les jambes longues et minces; (E) he's got legs like toothpicks

se dégourdir/ dérouiller les jambes faire une petite marche; (E) to stretch one's legs

se faire taper dans les jambes (1931) (cf. donner du dos)

se mettre dans les jambes de qqn gêner qqn; (E) to get under s.o.'s feet se sauver à toutes jambes

(cf. prendre ses jambes à son COU 1)

selon la jambe le bas (1640)

(cf. selon le bras la saignée)

selon la jambe la chausse (1568) (cf. ci-dessus)

si vous lui donnez un pied, il vous prendra la jambe

(cf. si on lui en donne un pouce, il en prendra grand comme le BRAS)

sur une jambe (1872)

(cf. les DOIGTS dans le nez)

tenir la jambe à qqn (1901)

importuner qqn en le retenant par une conversation sans fin; (E) to buttonhole s.o.

tirer dans les jambes de qqn

(cf. tirer dans le dos de qqn)

tirer/ traîner la jambe (20)

marcher avec peine; (E) to have a stiff gait

traiter qqch par-dessous la jambe (1844)

(cf. à la mords-moi le doigt)

traiter qqn par-dessous la jambe (1829)

traiter qqn avec désinvolture, avec mépris;

(E) to treat s.o. in an offhand manner

tricoter des jambes

(cf. prendre ses jambes à son COU 2)

JARRET

avoir du jarret

(cf. avoir de bonnes jambes)

avoir les jarrets souples (1640)

(cf. avoir les genoux bien graissés)

coupe-jarret (17) assassin; (E) cut - throat

elle ne fait que secouer le jarret (17)

elle accouche avec facilité; (E) she gives birth very easily

raidir/ secouer le jarret (1640)

1. cf. avoir la mort entre les dents

2. mourir; (E) to lay the bones at rest, to go home/ out feet first (US), to go off feet foremost, to go the way of all flesh (US), to kick up/ turn up one's heels, to go to grass with one's teeth upwards, to cock up/ curl up/ turn up one's toes, to turn up one's toes to the daisies

tendre le jarret (17)

faire la révérence; (E) to make a leg

JOUE

avoir de bonnes joues

(cf. avoir le CUL sur le visage)

avoir la maladie saint Boudon, les joues plates

comme une boule (1640)

(cf. ci-dessus)

avoir les joues avalées/ cousues (1894)

(cf. la peau lui tient aux CÔTES)

battre les joues de qqn (1640)

gifler qqn; (E) to catch s.o. a belt on the ear (hole), to give s.o. a clip on the ear/ a thick ear, to box/ warm s.o. ears, to pin s.o.'s ears back (US), to slap s.o.'s face, to give s.o. a sock on the jaw

coucher en joue (1690)

1. diriger ses vues sur qqch ou qqn; (E) to have designs on sthg or s.o.

2. menacer; (E) to threaten

coucher en joue une femme (1867)

draguer une femme; (E) to chase a woman

couvrir la joue à qqn (1640)

(cf. battre les joues de qqn)

il a bien refait ses joues (1640) il a repris du poids; (E) he has put on weight

il s'en est calé les joues (1690) il a dépensé son bien en ripailles; (E) he squandered his money on feasting

les joues lui passent le nez (1640)

il est trop gros; (E) he is a pot-belly

mettre en joue (1624)

(cf. coucher en joue)

présenter l'autre joue (Matthieu, 5, 39) se montrer magnanime; (E) to turn the other cheek

se battre les joues (1640) regretter ses paroles; (E) to bite one's tongue

se caler les joues (1875)

(cf. se caler les amygdales)

se donner de qqch par les joues (1640) manger tout son saoul de qqch; (E) to eat sthg to one's heart content

se donner par les joues (1606)

s'enrichir; (E) to make money hand over fist

s'en battre les joues (1690)

(cf. se torcher le cul de qqch) 
tendre l'autre joue

(cf. présenter l'autre joue)

LANGUE

avaler sa langue (19)

1. cf. demeurer bouche close

2. cf. raidir le jarret 2

avoir avalé sa langue (19)

(cf. demeurer bouche close)

avoir la langue (bien) affilée (14)

1. cf. la parole ne lui meurt pas dans la

bouche

2. être très bavard, parler sans arrêt; (E) to talk one's head off, to have a good jaw, to have diarrhea of the jawbonel mouth (US), to run off at the mouth (US), to shoot one's mouth off, to have tongue enough for two sets of teeth, to enjoy a good tongue-wag, to have a well-oiled tongue (US)

avoir la langue bien longue (1640)

1. cf. avoir la langue (bien) affilée 2

2. manquer de discrétion; (E) to blab one's mouth, to open one's mouth too wide, to shoot off one's mouth, to mouth off, to be a blabbermouth, to have a loose tongue (US), to have a tongue too long for one's mouth/ teeth

avoir la langue bien pendue (1424)

(cf. la parole ne lui meurt pas dans la bouche)

avoir la langue grasse (1640)

1. cf. avoir de la bouillie dans la bouche

2. dire des grossièretés; (E) to use coarse language

avoir la langue liée

être contraint au silence; (E) to be tonguetied

avoir la langue pâteuse

(cf. avoir mal aux cheveux)

avoir la langue qui fourche (17)

commettre un lapsus; (E) to make a slip of the tongue

avoir perdu sa langue (20)

(cf. demeurer bouche close)

l'avoir sur le bout de la langue être près de trouver le mot qui échappe;

(E) to have it on the tip of one's tongue

avoir un bœuf sur la langue (19)

garder un silence obstiné; (E) to keep one's lip buttoned up (US), to have one's lips sealed, to keep a watch on one's tongue

avoir un cheveu sur la langue (20)

(cf. cheveu)

avoir un plomb sur la langue

garder un secret; (E) to keep a secret beau parler n'écorche point la langue (1557) la politesse n'est pas un défaut; (E) cool words scald not the tongue, to keep a civil tongue in one's head

ça lui brûle la langue il est tenté de le dire; (E) he is burning to speak

c'est une langue de la Pentecôte (1842)

c'est un médisant qui n'épargne personne; (E) he is a scandal monger who spares nobody

coup de langue (1640)

1. reproche; (E) blame, reproach

2. offense; (E) offence

délier la langue à qqn forcer qqn à parler; (E) to loosen s.o.'s tongue

donner du plat de la langue à qqn (1640) (cf. tâter le biceps à qqn)

donner sa langue au chat (1845)/ aux chiens

(17)

renoncer à deviner; (E) to give up guessing

est-ce que tu as perdu ta langue?

se dit à un enfant qui refuse de répondre;

(E) has the cat got your tongue?

faire aller/ marcher les langues provoquer les cancans; (E) to set tongues wagging

faire tirer la langue à qqn faire désirer longtemps; (E) to keep s.o. waiting for what he wishes

faire une langue fourrée (19) (cf. se lécher les amygdales)

il a la langue à la bouche et non à la bourse (1640)

(cf. bouche)

il n'aura pas de langue pour la moitié de sa vie (1690)

il est très bavard; (E) he has tongue enough for two sets of teeth, his tongue is hinged in the middle and he talks with both ends

il vaut mieux glisser du pied que de la langue (1842)

il est souvent préférable de se taire; (E) better the foot slip than the tongue, let not your tongue cut your throat

jeter sa langue $\mathrm{au}(\mathrm{x})$ chien(s) (17)

(cf. donner sa langue au chat)

la langue des femmes est leur épée et elles ne la laissent pas rouiller (1842)

les femmes sont bavardes; (E) a woman's strength is in her tongue, a woman's tongue is the last thing about her that dies, one tongue is enough for a woman 
la langue du sage est dans son cœur, le cœur du sot est dans sa bouche (Ecclésiaste, 21, 26)

(cf. BOUCHE en cœur au sage..)

la langue lui va comme le cliquet/ traquet d'un moulin (1640)

(cf. il n'aura pas de langue pour la moitié de sa vie)

la langue lui va comme la navette d'un tisserand (1690)

$$
\text { (cf. ci-dessus) }
$$

la langue me dit vas-y vas-y (1640) (cf. mes boyaux crient vengeance)

la langue va où la dent fait mal (1842) (cf. dent)

langue de serpent (1640)/ de vipère (1690) médisant; (E) gatemouth, slanderous tongue

langue de tripière (1640) personne grossière; (E) coarse person

les absents sont assassinés à coups de langue (Scarron, 1651)

(cf. tomber sur le corps à qqn 2)

les belles paroles n'écorchent pas la langue (1640)

(cf. beau parler n'écorche point la langue)

longue langue, courte main (1568)

(cf. il a la langue à la BOUCHE et pas à la bourse)

mauvaise langue

(cf. langue de serpent)

mordre la langue à qqn (1970)

(cf. mettre qqn au trou de son cul)

n'avoir point de langue

1. cf. demeurer bouche close

2. être avare de paroles; (E) to be sparing of one's words

n'avoir pas sa langue dans sa poche (1768)

(cf. la parole ne lui meurt pas dans la bouche)

ne pas savoir tenir sa langue (17)

être incapable de se taire, de garder un secret; (E) not to be able to hold one's tongue

prendre langue (1614)

entrer en contact, s'aboucher avec qqn;

(E) to get in touch with s.o.

qui langue a, à Rome va (13)

en s'expliquant on arrive à ses fins; (E) the

lame tongue gets nothing

retrouver sa langue

retrouver la parole; (E) to find one's tongue

sa langue va toujours (1690)

(cf. il n'aura pas de langue pour la moitié de sa vie)

se mordre la langue

1. cf. se battre les joues
2. se taire au moment opportun; (E) to bite one's tongue off

se servir de sa langue (1864)

(cf. se mettre une fausse barbe)

tenir sa langue (1636)

(cf. demeurer bouche close)

tirer la langue (1867)

1. cf. avoir le gosier sec

2. cf. être à cul 1

tirer la langue à/ sur qqn (1611)

(cf. faire la barbe à qqn 4 )

tirer la langue après qqch

désirer qqch ardemment; (E) to have one's

tongue hanging out for sthg

tirer la langue d'un pied de long (1640)

1. cf. tirer la langue 1

2. cf. tirer la langue après qqch

tourner sept fois sa langue en bouche avant de parler (1835)

(cf. bouche)

un coup de langue est pire qu'un coup de lance (17)

les mots peuvent faire plus mal qu'une

blessure; (E) the tongue breaks bone though itself has none, the tongue is not steel yet it cuts, the tongue is sharper than any sword

\section{LÊVRE}

acquiescer du bout des lèvres (1677)

accepter de mauvais gré; (E) to assent reluctantly

avoir encore le lait sur les lèvres

être jeune, naïf, inexpérimenté; (E) to be still wet behind the ears, not to have cut one's eye-teeth yet

avoir l'âme/ la mort sur les lèvres

(cf. avoir la mort entre les dents)

avoir le cour au bord des lèvres (19)

(cf. cœur)

avoir le cœur sur les lèvres

(cf. cœur)

avoir sur le bord des lèvres (1690)

(cf. avoir sur le bout de la langue)

brûler les lèvres

(cf. ça lui brûle la langue)

être suspendu aux lèvres de qqn (19)

écouter qqn avec grande attention; (E) to

hang on s.o.'s lips

il le dit des lèvres, mais le coeur n'y est pas (17)

(cf. il dit cela de la BOUCHE, mais le cour n'y est pas)

il y a loin de la coupe aux lèvres (16)

1. cf. il arrive bien des choses entre la bouche

et le verre

2. c'est là tout autre chose; (E) that's quite

another thing 
manger du bout des lèvres (17)

(cf. faire la petite bouche 2)

ne connaître qqn ni des lèvres ni des dents (20) (cf. dent)

ne pas desserrer les lèvres

(cf. demeurer bouche close)

parler du bout des lèvres (17)

1. cf. parler la BOUCHE en cœur

2. parler d'un air dédaigneux; (E) to speak disdainfully

pincer les lèvres

prendre un air dédaigneux, hautain; (E) to prim (up) one's lips/ mouth, to purse one's lips

pincer les lèvres pour ne pas rire

faire effort pour garder son sérieux; (E) to bite/ pinch one's lips in order not to laugh qu'un autre te loue et non ta bouche, un étranger et non tes lèvres (Livre des Proverbes, 27,2)

(cf. bouche)

rire du bout des lèvres

(cf. rire comme un cul)

s'en mordre les lèvres

(cf. s'en mordre les doigts 2)

se mordre les lèvres

1. cf. pincer les lèvres pour ne pas rire

2. cf. se battre les joues

son rire ne passe pas les lèvres

son rire est affecté, forcé; (E) his laugh is never genuine

MÂCHOIRE

baîller à se décrocher / démantibuler la mâchoire (19)

1. cf. en avoir plein le cul 2

2. avoir fort sommeil; (E) to yawn one's head off

branler la mâchoire (1690)

(cf. se caler les amygdales)

dauber/ jouer des mâchoires (1640)

(cf. ci-dessus)

mâchoire pesante (1690)

(cf. cerveau à bourrelets 1 )

mot/ nom à se décrocher la mâchoire

mot ou nom difficile à prononcer; (E) tonguetwister

rire à se décrocher la mâchoire

(cf. se tenir les côtes)

s'entretailler des mâchoires (1640)

1. cf. avoir de la bouillie dans la bouche

2. cf. se couper la gorge 2

s'escrimer/ travailler des mâchoires

(cf. se caler les amygdales)

vieille mâchoire (1808)

(cf. vieux cul)
MAIN

à main levée

1.vote public sans bulletin; (E) (vote) by a

show of hands

2. exécution sans accessoires (dessin, etc.);

(E) freehand (drawing, etc.)

à pleines mains

abondamment, sans compter; (E) by the

handful, in handfuls

à un vilain, tends-lui le doigt, il prendra toute la main (1640)

(cf. si on lui en donne un pouce, il en prendra grand comme le BRAS)

accorder sa main (17)

accepter la demande en mariage; (E) to give one's hand (to a suitor)

agir de haute main (17)

agir avec intransigeance; (E) to act with a high hand

aller bride en main (1690)

ne pas prendre de risques; (E) not to take any chances

applaudir des deux mains (20

approuver sans réserve; (E) to approve unreservedly

applaudir qqn des deux mains (20) applaudir chaleureusement; (E) to give s.o. the big hand

attendre de la main gauche (1640) manger de la main droite seulement en attendant l'absent; (E) to eat with the right hand only while waiting for the absent person

au paresseux, le poil lui pousse dans la main (1842)

(cf. avoir les bras cassés)

au petit galop, les mains basses (1925)

(cf. les DOIGTS dans le nez)

aux innocents les mains pleines (1842)

la chance sourit aux débutants; (E) fortune

favours fools, beginners have all the luck

avoir qqn à sa main (1927)

(cf. tenir le pied sur la GORGE à qqn 2)

avoir bien en main

avoir une bonne prise sur; (E) to have well in hand

avoir des mains de beurre (17)

être très maladroit; $(\mathrm{E})$ to be a butterfingers, to be ham-/ two-fisted, to have two left hands, to be ham-handed, to be all thumbs avoir des mains de laine et des dents de fer (cf. dent)

avoir des mains en or

(cf. avoir de l'esprit au bout des doigts) 
avoir la balle en main (1640)

(cf. avoir du cul)

avoir la haute main (sur qqch)

avoir tous pouvoirs; (E) to have a high hand avoir la main

1. jouer le premier (aux cartes) (1690);

(E) to have the deal

2. avoir du succès au jeu (1872); (E) to have

a run of luck (at games)

avoir la main à la pâte (1690)

travailler soi-même à ses affaires; (E) to do

sthg with one's own hands, to put one's hand to the plough, to get one's feet wet (US)

avoir la main baladeuse (20)

se permettre des caresses intimes; (E) to

have wandering hands

avoir la main bonne (1690)

1. cf. avoir du cul

2. cf. avoir de l'esprit au bout des doigts avoir la main bonne pour chanter et la voix bonne pour écrire (1640)

écrire et chanter très mal; (E) to be no good at both writing and singing

avoir la main chaude (1690)

(cf. avoir la main 2)

avoir la main heureuse (1781)

(cf. avoir du cul)

avoir la main légère (1690)

1. cf. avoir de l'esprit au bout des doigts

2. avoir la gifle facile; (E) to be quick to chastise

avoir la main leste (19)

(cf. avoir la main légère 2)

avoir la main lourde

1. cf. avoir des mains de beurre (17)

2. punir sévèrement; (E) to be heavy-handed

3. trop épicer un mets; (E) to put too much of a spice in a dish

avoir la main putain (1867)

serrer la main à n'importe qui; (E) to shake

hands with anybody

avoir la main verte (20)

être bon en jardinage; (E) to have green

fingers, to have a green thumb

avoir le cœur sur la main (1779)

(cf. cœur)

avoir les mains à la retourne

(cf. avoir les bras cassés)

avoir les mains bien longues (1690)

(cf. avoir le bras long)

avoir les mains blanches (19)

vivre sans devoir travailler; (E) to live

without having to work

avoir les mains faites en chapon rôti (1640)

1. cf. avoir les doigts crochus
2. avoir des mains déformées de goutteux;

(E) to have gouty fingers

avoir les mains libres (16)

être libre d'agir à son gré; (E) to have elbow-

room, to have a free hand

avoir les mains liées (1640)

être empêché d'agir; (E) to have one's hand tied

avoir des mains nettes (1640)

n'avoir commis aucune action répréhensible;

(E) to keep one's hands/ nose clean

avoir les mains nettes en qqch (1690)

ne pas être mêlé à qqch; (E) to have no hand in sthg

avoir les mains palmées

(cf. avoir les bras cassés)

avoir sous la main (17)

avoir à sa portée; (E) to have at one's elbow,

to have close at hand/ near at hand/ ready to hand

avoir toujours la main à la poche

dépenser sans compter; (E) to spend money with both hands

avoir tous les atouts en main (20)

avoir toutes les chances de son côté; (E) to

hold all the trumps

avoir un poil dans la main (1808)

(cf. avoir les bras cassés)

battre/ frapper des mains (16) applaudir; (E) to clap one's hands

bon cavalier monte à toute main

l'homme adroit réussit dans toutes ses entreprises; (E) a clever man will always succeed in his undertakings

c'est une partie faite à la main! (1690) c'est un coup monté; (E) it's a put-up job!

changer de main (16)

changer de propriétaire; (E) to change hands

clefs en main (20)

(bâtiment livré) entièrement terminé;

(E) all-in (referring to a building)

coup de main

1. entreprise audacieuse (1690); (E) raid

2. assistance momentanée (1801); (E)

(helping) hand

3. adresse, habileté; (E) knack

courroux est vain sans forte main (1568)

la menace est vaine si on ne peut la mettre à exécution; (E) if you cannot bite, never show your teeth

de la main à la main

sans intermédiaire; (E) from hand to hand

de longue main (14)

de longue date, depuis longtemps; (E) of

long standing 
de main de maître (1539)

à la perfection; (E) by a master hand

de mains vides, prières vaines (1568)

on ne prête qu'aux riches; (E) people lend only to the rich

de marchand à marchand, il n'y a que la main (1690)

entre marchands il n'y a pas d'écrit pour faire affaire; (E) an honest man's word is as good as his bond

de première main (17)

d'origine, neuf; directement; (E) firsthand

de seconde main (17)

d'occasion; indirectement; (E) secondhand

demander la main (d'une jeune fille) (17)

faire sa demande en mariage; (E) to make a

formal proposal of marriage

des deux mains

avec empressement; (E) eagerly

des pieds et des mains

(cf. à belles DENTS, à belles ongles)

Dieu regarde les mains pures plutôt que les mains pleines

la vertu l'emporte sur les riches offrandes;

(E) clean hands are better than full ones in the sight of God, God looks to pure hands not full ones, virtue dwells not on the tongue but in the heart

donner de la main à qqn (1640)

(cf. battre les joues à qqn)

donner la main à qqn (17)

(cf. prêter son bras)

donner les mains (1656)

consentir, s'incliner; (E) to consent, to give in

donner un coup de main à qqn (19)

(cf. prêter son bras)

du cousu main (20)

(cf. de main de maître)

écarter d'un revers de la main

accorder peu d'importance à, considérer comme négligeable; (E) to brush aside

en avoir plein les mains

(cf. en avoir par-dessus les épaules 2)

en mains propres

personnellement; (E) in s.o.'s own hands

en mains sûres

en sécurité; (E) in safe hands

en mettre la/ sa main à couper/ au feu (17)

être sûr de ce qu'on avance; (E) to stake

one's life on it

en sous-main (16)

en cachette, à la dérobée; (E) in an underhand way en un tour de main (1640)

(cf. en un CIL d'œil)

en venir aux mains (16)

en arriver à se battre; (E) to come to blows

être aux mains (1690)

(cf. se prendre aux cheveux)

être aux mains de qqn (17)

(cf. être aux genoux de qqn)

être comme les (deux) doigts de la main (1640)

(cf. n'être qu'un en deux corps)

être en bonne main (1690)/ en de bonnes mains

1. appartenir à un puissant; (E) to belong to

a mighty person

2. avoir affaire à forte partie; (E) to have a

powerful opponent

3. être aux bons soins de qqn; (E) to be in good hands

être en main

1. être bien disposé pour faire qqch (1640);

(E) to feel like doing sthg

2. être occupée avec un client, en parlant

d'une prostituée (19); (E) to be with a client (prostitute)

3. être sous la coupe d'un proxénète (19);

(E) to be in the hands of a pimp

être entre les mains de qqn

(cf. être aux genoux de qqn)

être haut de la main (1640)

(cf. agir de haute main)

être léger de la main (1690)

(cf. avoir la main légère)

être pris la main dans le sac (19)

être pris en flagrant délit; (E) to be caught

red-handed/ red-headed/ with one's hand in the till

être sous la main de qqn

(cf. être aux genoux de qqn)

faire crédit de la main à la bourse (17)

exiger le paiement comptant; (E) to request payment in cash

faire des pieds et des mains (20)

mettre tout en œuvre, faire tout son

possible; (E) to strain every nerve (to achieve sthg)

faire main basse sur qqn

1. cf. y mettre le doigt (19)

2. mettre à sac $(1611) ;(E)$ to pillage

3. attraper, saisir; (E) to lay hands on

faire main forte (1640)

(cf. prêter son bras)

faire sa main (1640)

(cf. se donner par les joues)

faire un coup de sa main (1690)

entreprendre qqch d'autorité, de son propre chef; (E) to do sthg on one's own authority 
faire une main levée (1828)

(cf. y mettre le doigt)

faire une main tombée

1. cf. y mettre le doigt (1952)

2. caresser discrètement le derrière d'une femme (1960); (E) to have one's fingers in the fruit basket, to slip the hand

faites du bien à un vilain, il vous fera dans la main (13)

l'ingratitude est humaine; (E) man is ungrateful

fermer la main à qqn (1690)

empêcher qqn de payer ce qu'il doit; (E) to stop s.o. from paying his due

forcer la main à qqn (18)

contraindre qqn; (E) to strong-arm s.o. (into doing sthg), to twist s.o.'s arm, to force s.o.'s hand

froid aux mains, chaud au cœur; froides mains,

chaudes amours (1527)

(cf. cœur)

gagner haut la main

l'emporter facilement; (E) to win hands down

garder la haute main sur garder le contrôle; (E) to keep the upper hand on

gens de main morte (1690)

personnes de condition servile; (E) people of dependent condition

graisser la main à qqn (1624) corrompre qqn; (E) to grease/ oil s.o.'s palm

haut la main

1. cf. les DOIGTS dans le nez

2. d'autorité (1670); (E) with a high hand

homme de main (16) agent d'exécution; (E) hired killer

il a toujours la main levée (1640) il est toujours prêt à frapper; (E) he is always ready to slap

il a toujours les mains dans ses poches (1690) (cf. cul de plomb 2)

il faut plutôt prendre garde/ regarder à ses mains qu'à ses pieds (1640)

c'est un voleur, il faut se méfier de lui; (E) his fingers are made of lime twigs

il faut que la main gauche ignore le bien que fait la main droite (Matthieu, 6, 3)

le bien que l'on fait doit être discret; (E) let your left hand know nothing of the good done by your right hand, let not thy left hand know what thy right hand doeth

il n'y a que la main d'un ami qui arrache l'épine du cœur

(cf. cœur) il ne va pas sans ses mains (1690)

c'est un voleur invétéré; (E) he is a confirmed thief

il passera par mes mains! (1640)

je le corrigerai, je le punirai; (E) he'll get it in the neck!, I'll skin him alive!

il vaut mieux tendre la main que le cou (1690)

(cf. il vaut mieux allonger le BRAS que le $\mathrm{col}$ )

ils ont toute la pâte entre leurs mains (1640) ils détiennent tous les emplois, tous les commerces; (E) they have all the jobs, all the trade

imposer les mains sur qqn (1690)

(cf. rompre BRAS et jambes à qqn)

imposition des mains (1640) correction, volée de coups; (E) trashing

je n'en mettrais pas la main au feu! (17) (cf. je n'en voudrais pas mettre le doigt au feu)

jeu de mains, jeu de vilains! (1690)

il ne faut pas s'amuser à se battre; (E) no horseplay!

joindre les mains, c'est bien, les ouvrir, c'est

mieux (Ratisbonne, 1860)

il faut ajouter l'aumône à la prière;

(E) prayers should not go without alms

jouer à la main chaude (1867) être guillotiné; (E) to hop headless

l'amour n'est pas un feu que l'on tient dans la main (1559)

l'amour est un sentiment qu'on ne peut rejeter quand on veut; (E) love cannot be discarded as one pleases

l'argent est une troisième main (Toulet, 1922) l'argent facilite bien des choses; (E) money helps in many ways

la main du cœur (1640) (cf. cœur)

la main est le plus sûr et le plus prompt secours

(La Fontaine, 1678) un métier manuel nourrit toujours son homme; (E) a manual trade will always earn one's bread and butter

lâcher la main (1690) réduire ses prétentions; (E) to reduce one's claims

lâcher la main à qqn (1690)

(cf. laisser la bride sur le cou à qqn)

le roi a de longues mains (1752)

les grands sont tout puissants; (E) kings have long arms

les cinq doigts de la main ne se ressemblent pas (cf. doigt) 
les doigts d'une main ne s'entresemblent pas (15)

$$
\text { (cf. doigt) }
$$

les mains lui démangent

1. il a envie de frapper (14); (E) his fingers are tingling to strike

2. il a envie d'écrire (quelque critique, etc.)

$(1690)$; (E) he is itching to write (some criticism, etc.)

les mains noires font manger le pain blanc le travail procure l'aisance; (E) work brings well-being

les mains sont faites avant les couteaux (1640) formule d'excuse lorsqu'on se sert avec les doigts; (E) an apology when on helps oneself with one's fingers

les mains sous le menton, les coudes sur la table (1690)

(cf. coude)

les os lui tombent de la main (1640)

(cf. les os lui sortent des DOIGTS)

lever la main (1640)

prêter serment; (E) to take an oath, to be sworn in

lever la main sur qqn (1640)

frapper ou menacer de le faire; (E) to lay hands on s.o., to raise one's hand against s.o.

lever les mains au ciel (1690) (cf. lever les bras au ciel)

lier les mains à qqn (1690) empêcher qqn d'agir; (E) to tie s.o.'s hands

longue langue, courte main (1568) (cf. langue)

lutter des pieds et des mains se battre avec acharnement; (E) to fight tooth and nail

main d'œuvre personnel ouvrier; (E) hands

main de fer autorité vigoureuse; (E) firm hand

main de velours, cœur de beurre; main

d'ouvrage, cœur de courage (cf. cœur)

mains courantes (1876) les pieds; (E) the feet

manger dans la main de qqn (1867) 1. obéir aveuglément à qqn (1867); (E) to eat out of s.o.'s hand 2. être familier avec qqn; (E) to slap s.o.'s back, to dig/ poke s.o. in the ribs

marcher la main dans la main avec qqn agir de concert, être d'intelligence; (E) to go hand in hand with s.o.

mariage de la main gauche (20) concubinage; (E) left-handed marriage mettre la dernière main à qqch (1640) terminer, parfaire qqch; (E) to give the finishing touch to sthg

mettre la main à qqch (12) entreprendre qqch; (E) to put one's hand to the plough, to take a hand in sthg, to get one's teeth into sthg

mettre la main à l'encensoir (1690) vouloir prendre sur le bien du clergé; (E) to seize on the possessions of the clergy

mettre la main à l'héritage (1690) mettre la main à terre pour ne pas tomber tout à fait; (E) to touch ground with one's hand in order not to fall

mettre la main à l'œuvre / la charrue (1690) (cf. mettre la main à qqch)

mettre la main à la (1690)/ sur sa (1640)

conscience

faire son examen de conscience; (E) to examine one's conscience mettre la main à la pâte

1. cf. avoir la main à la pâte (1640)

2. cf. prêter son bras (1708)

mettre la main au chapeau (1690)

saluer qqn; (E) to touch one's hat to s.o.

mettre la main au collet à qqn (17)

(cf. saisir qqn au corps)

mettre la main au panier (1890)

(cf. faire une main tombée 2)

mettre la main sur qqch (1160)

1. cf. faire main basse sur qqch 3

2. trouver ce qu'on cherchait; (E) to put one's hand on sthg, to lay hands on sthg

mettre la main sur le paletot à qqn (1936)

(cf. saisir qqn au corps)

mettre le marché à la main de qqn/ en la main à qqn (1690)

inciter qqn à conclure l'affaire; (E) to incite s.o. to close the deal

mettre le pain à la main de qqn (1640)

donner à qqn des moyens d'existence; (E) to give s.o. the means of a living

mettre la/ sa main au feu (17)

(cf. mettre le doigt au feu)

mettre les mains sous le menton prendre ses aises; (E) to make oneself comfortable

mettre les mains sur les rognons (1690) (cf. mettre les poings sur les HANCHES)

montre en main (19)

ponctuellement, très précisément; (E) on the nose

n'avoir pas les mains gourdes (1690)

1. cf. avoir les doigts crochus 2

2. être prompt à faire qqch; (E) to be quick in doing sthg 
ne pas avoir les mains dans les poches être actif, efficace; (E) to be alert, efficient ne pas se faire d'ampoules aux mains (19) (cf. avoir les bras cassés)

ne pas se moucher de la main gauche (19) (cf. ne pas se moucher du coude)

ne pas y aller de main morte (1640) agir avec force, sans retenue; (E) to make no bones about it, to go it bald-headed

nu comme la main

1. cf. être dans le pétrin jusqu'au cou 2 (1690)

2. complètement nu (1640); (E) bare as the back of one's hand

on peut les compter sur les doigts de la main (cf. doigt)

parler le cour dans la main (1690)

(cf. avoir le cour à la BOUCHE)

partir de la main (1640)

agir avec promptitude et résolution; (E) to act quickly and resolutely

passer la main (1909)

1. cf. baisser les bras

2. céder son tour à autrui; (E) to hand it over to s.o.

passer la main dans les cheveux à qqn (19)

(cf. tâter le biceps à qqn)

passer la main dans le dos à qqn (19) (cf. ci-dessus)

perdre la main n'avoir plus la pratique; (E) to lose the knack of

péter dans la main (1867)

faire défaut au moment requis; (E) to nosedive (US)

péter dans la main à qqn (1867)

(cf. manger dans la main de qqn 2)

petite main (1910)

apprentie couturière; (E) apprentice dressmaker

porter la main sur qqn (1640)

(cf. lever la main sur qqn)

pouvoir se donner la main (19)

se ressembler en mainte chose; (E) to be alike in many things

prendre à toutes mains (1640)

se procurer par bons ou mauvais moyens;

(E) to take by fair means or foul

prendre en main (1160)

se charger de, assumer; (E) to take in hand

prendre qqn la main dans le sac (19)

attraper qqn sur le fait; (E) to catch s.o. with his hand in the till, to catch s.o. red-handed/ red-headed prendre son courage à deux mains (1835)

être déterminé à faire qqch; (E) to take one's courage in both hands

prêter la main à (1636)

(cf. prêter son bras)

prêter main forte (1640)

(cf. ci-dessus)

qui a besoin de feu le prend avec la main (1612) nécessité n'a point de loi; (E) necessity has no law

revenir les mains vides avoir échoué, revenir bredouille; (E) to return empty-handed

sans main mettre (1640) sans apporter argent ou concours;

(E) without any help or money

se dépatouiller des mains de qqn (1640)

se libérer de l'emprise de qqn; (E) to free oneself from s.o.'s influence

se donner la main (1694)

(cf. se serrer les coudes)

se faire la main sur qqch

s'exercer à, se familiariser avec; (E) to cut one's eyeteeth on, to get one's hand in, to try one's hand at/ on

se frotter les mains (18)

montrer sa satisfaction, se réjouir; (E) to rub one's hands

se laisser manger dans la main (18) se résigner; (E) to resign oneself

se laver les mains de qqch (17) se déclarer innocent, se mettre à l'abri des reproches; (E) to wash one's hands of sthg

se marier de la main gauche $(20)$

cohabiter; (E) to marry over the broomstick

se passer la main dans le dos

(cf. se donner des coups de pied dans les CHEVILLES)

se prendre en main se ressaisir; (E) to get one's head together

se salir les mains se livrer à des pratiques répréhensibles;

(E) to get involved in shady dealings

se servir de sa main (1864)

(cf. se faire sauter la cervelle 2 )

serrer la main à qqn (16)

saluer qqn; (E) to shake hands with s.o.

sous la main

1. cf. avoir sous la main (17)

2. cf. en sous-main (16)

tard la main à la bouche quand la parole est issue (cf. bouche)

tendre la main (1606)

(cf. allonger le bras) 
tendre la main à qqn (13)

(cf. prêter son bras)

tenir (qqn) dans le creux de sa main

(cf. tenir le pied sur la GORGE à qqn 2)

tenir qqch de bonne main

tenir de bonne source; (E) to have sthg on good authority

tenir la main à qqch (1690)

veiller à l'exécution de qqch; (E) to make sure that sthg is done

tenir la main haute à qqn (1690)

laisser peu de liberté à qqn; (E) to keep s.o. in hand

tenir son sérieux à pleines mains (1894)

(cf. se pincer les lèvres pour ne pas rire)

tomber aux mains/ dans/ entre les mains de qqn (1640)

(cf. tomber sous la dent de qqn)

tomber des mains (1896)

échapper; (E) to drop out of one's hands

tomber sous la main (17)

se trouver à portée de manière fortuite;

(E) to find by chance

tout d'une main (1640)

sans discontinuer; (E) on end, without a break

un bon avis vaut un oeil dans la main (1842)

un bon conseil éclaire sur la conduite à tenir; (E) a good advice is beyond price un moineau dans la main vaut mieux qu'une grue qui vole

il faut préférer un petit avantage qui est certain à un plus grand qui ne l'est pas;

(E) a bird in the hand is worth two in the bush

une main de fer dans un gant de velours (19)

la fermeté sous la douceur; (E) a hard fist

under a velvet glove, an iron hand in a velvet glove

une main lave l'autre

1. les parents/ les alliés se doivent une mutuelle assistance (1690); (E) you scratch my back and I'll scratch yours, one hand washeth the other and both the face 2. se disculper l'un l'autre (1835); (E) to clear one another

venir aux mains (16)

(cf. en venir aux mains)

\section{MANDIBULE}

claquer des mandibules

1. cf. battre le tambour avec les dents

2. cf. avoir la dent

faire marcher ses mandibules (1866)

(cf. se caler les amygdales) jouer des mandibules (1867)

(cf. ci-dessus)

jouer la polka des mandibules (1982)

(cf. ci-dessus)

\section{MÉNINGES}

infirme des méninges (1953)

(cf. cervelle à double rebras)

ne pas se fouler les méninges (19)

ne pas se fatiguer l'esprit; (E) not to overtax one's brains

se baratter/ casser/ creuser/ fatiguer/ fouler les

méninges (20)

(cf. s'alambiquer le cerveau)

MENTON

avoir de la barbe au menton (1872)

(cf. barbe)

branler le menton (1690)

(cf. se caler les amygdales)

cela lui a haussé le menton (1640)

cela l'a rendu prétentieux; (E) he's got a big/

swelled/ swollen head, he suffers from

swelled head

en avoir jusqu'au menton

(cf. en avoir plein le cul 2)

être grosse jusqu'au menton

(cf. être en cloque jusqu'aux genoux)

hausser le menton (1640)

1. cf. faire le crâne

2. dédaigner, mépriser; (E) to look down

one's nose at

hausser le menton à qqn (1640)

frapper qqn au menton; (E) to chuck s.o. under the chin

il est facile de nager quand on vous tient le menton (13)

avec de l'aide tout devient facile; (E) all is easy with some help

jusqu'au menton

(cf. jusqu'au cou)

les mains sous le menton, les coudes sur la table (1690)

(cf. coude)

lever le menton à qqn (1690) aider qqn dans son entreprise; (E) to help s.o. in his undertaking

menton bleu cabotin ; (E) third-rate actor

menton de (1704)/ en (1867) galoche menton pointu et recourbé; (E) nutcracker chin, undershot jaw

menton en casse-noisettes (cf. ci-dessus)

mettre ses mains sous le menton (cf. main) 
rabaisser le menton à qqn (1640) humilier qqn; (E) to humble s.o.

relever le menton à qqn (1640)

(cf. hausser le menton à qqn)

sa bouche dit à ses oreilles que son menton

touche son nez (1842)

(cf. bouche)

s'en mettre jusqu'au menton

(cf. se caler les amygdales)

secouer le menton (1690)

se moquer d'une réprimande; (E) not to care for reproof

soutenir le menton à qqn (1690)

(cf. lever le menton à qqn)

\section{MOELLE}

avoir de la moelle (1859)

(cf. avoir du CCEUR an ventre)

avoir la moelle (1982)

(cf. ci-dessus)

avoir la moelle de (faire qqch) (1928) avoir le courage, le cran de; (E) to have the guts to

être gelé jusqu'à la moelle (des os) (17) avoir très froid; (E) to be chilled/ frozen to the bonel the marrow

être pourri jusqu'à la moelle (19)

être tout à fait corrompu ; (E) to be rotten to the core

faire juter l'os à moelle (1907)

1. cf. se faire sauter la cervelle 2

2. se moucher (avec les doigts); (E) to blow one's nose (with one's fingers)

jusqu'à la moelle (17)

à fond, de part en part; (E) to the (back)bone, to the marrow

moelle (16)

1. cf. cour 3

2. cf. jus de corps d'homme

n'avoir pas de moelle dans les os

(cf. avoir des bras de saindoux)

os à moelle (1907)

1. cf. boyau

2. nez; (E) the nose

se ronger les moelles

(cf. être en cervelle)

se vider les moelles

(cf. se casser le cul)

sucer qqn jusqu'à la moelle

extorquer tout son argent à qqn; (E) to

bleed s.o. white

tirer la moelle des os à qqn

(cf. ci-dessus)

trempé jusqu'à la moelle (17)

mouillé de part en part; (E) drenched/ soaked/ wet to the skin

MOLLET

avoir des mollets de coq (19)

(cf. avoir la jambe tout d'une venue comme

la jambe d'un chien)

avoir les nerfs du mollet qui se chevauchent

(1984)

avoir la crampe; (E) to be seized with cramp

MOUSTACHE

donner sur la moustache à qqn (17)

(cf. casser la figure à qqn)

enlever sur la moustache (1690)

obtenir par violence; (E) to obtain by

violence

il a la moustache bien relevée (1640)

il s'est bien fait avoir; (E) he has been done

in the eye

porte-monnaie à moustaches (1910)

(cf. bouche d'en bas)

quand vous auriez la moustache encore mieux

relevée! (1640)

je ne vous crains pas; (E) I don't fear you!

relever la moustache à qqn (1640)

(cf. casser la figure à qqn)

se brûler la moustache

(cf. se casser les dents)

sous/ sur la moustache de qqn (1626)

(cf. à la barbe de qqn)

MUSCLE

avoir du muscle

(cf. avoir du biceps)

être tout nerfs et muscles

être en parfaite forme physique; (E) to be all thew and sinew/ all skin and whipcord

muscle (18)

(cf. boyau)

NARINE

en prendre plein les narines (1977)

(cf. avoir sur les doigts)

prendre qqch dans les narines (1977)

(cf. ci-dessus)

s'en jeter un (coup) dans les narines (1931)

(cf. s'arroser les amygdales)

NERF

avoir des nerfs d'acier

avoir le caractère bien trempé; (E) to have cast-iron/ steel nerves, to have thews of steel avoir du nerf (1671)

être d'un tempérament énergique; (E) to

have guts in one

avoir les nerfs à fleur de peau

(cf. être en cervelle)

avoir les nerfs à toute épreuve

(cf. avoir des nerfs d'acier) 
avoir les nerfs à vif/ agacés/ au bout des doigts/ en boule/ en pelote (20)

(cf. être en cervelle)

avoir les nerfs du mollet qui se chevauchent (1894)

(cf. mollet)

avoir ses nerfs (1868)

être irritable; (E) to be in a state of nerves

donner sur les nerfs à qqn (19)

(cf. faire la barbe à qqn 6)

du nerf! (1671)

un peu plus de vigueur!; (E) get your arse into gear!, put your back into it!, put a bit of elbow-grease into it!, put some guts into it!

être à bout de nerfs (1929)

être au bord de l'épuisement nerveux; (E) to have one's nerves frayed

être sur les nerfs (20)

(cf. être en cervelle)

guerre des nerfs (20)

tactique d'usure du moral ennemi; (E) war of nerves

manquer de nerf

(cf. avoir des bras en saindoux)

mettre les nerfs en pelote à qqn (1901)

(cf. faire la barbe à qqn 6) nerf

1. cf. boyau (17)

2. vigueur (1534); (E) physical strength

paquet de nerfs

personne nerveuse, tourmentée; (E) worryguts, bundle of nerves

passer ses nerfs sur qqch/ qqn (1876)

soulager son irritation sur qqch/ qqn; (E) to work out one's irritation on sthg/ s.o.

porter (1817)/ taper (1871) sur les nerfs à qqn

(cf. faire la barbe à qqn 6)

tirer du nerf (1864)

(cf. manger de la chair crue)

vivre sur les nerfs

être dans un état permanent de surexcita-

tion; (E) to live on one's nerves

NEZ

à œil ou nez malade, ne touche que du coude (17)

(cf. coude)

à vue de nez

1. à première vue $(20) ;(E)$ at first sight

2. approximativement $(1821)$; (E) at a rough estimate

aller le nez levé (1690)

(cf. marcher le front haut)

au nez de qqn (1608)

(cf. à la barbe de qqn) avoir bon $n e z$ (1587)

1. avoir un bon odorat; (E) to have a good nose

2. sentir les choses; (E) to have a nose for things, to have a gift for nosing things out avoir du nez

1. cf. avoir bon nez 2 (1611)

2. être bien avisé, prévoyant (1606); (E) to be well-inspired, far-seeing

avoir le nez cassé (1640)

être en mauvais état; (E) to be in a poor

shape

avoir le nez creux/ fin (19)

1. cf. avoir bon nez 2

2. être malin, perspicace; (E) to be shrewd avoir le nez long (1858)

(cf. faire une tête longue d'un BRAS)

avoir le nez piqué/ sale (1867)

(cf. avoir sa barbe)

avoir mis le nez sur le pavé (1690)

(cf. être à cul 1)

avoir qqn au nez (1846)/ dans le nez (1821)

(cf. ne pas porter qqn dans son cœur)

avoir un coup/ un verre dans le nez (1934)

(cf. avoir sa barbe)

avoir un pied de nez

1. être déçu dans ses espérances (17); (E) to

be crestfallen

2. être honteux et confus (1842); (E) to be confused and ashamed

avoir un trou dans le nez (1844)

(cf. avoir le gosier en pente)

avoir un trou sous le nez (1611)

(cf. va-de-la-bouche)

baisser le nez

(cf. avoir un pied de nez 2)

bouffer le nez à qqn (19) agresser verbalement, rudoyer qqn; (E) to bite/ snap s.o.'s head/ nose off, to jump down s.o.'s throat

brider le nez à qqn (1690)

(cf. faire la barbe à qqn 3)

ça lui pend au nez! (14)

(cf. ça lui pend au cul!)

ça lui pend au nez comme un sifflet de deux sous (20)

(cf. ci-dessus)

ça te retombera sur le nez! (1797)

le blâme retombera sur toi; (E) you're sure to get the blame for it!

camus de Lamballe, un pied et demi de nez (1640)

individu au long nez; (E) person with a long nose 
casser l'encensoir sur le nez de qqn (18) louanger qqn à l'excès; (E) to praise s.o. fulsomely

ce n'est pas pour ton nez! (1640) cela n'est pas pour toi; (E) that's not for the likes of you!

ce que vous dites n'a point de nez! (1640) cela n'est pas trop bon; (E) that's not very good!

cela lui a haussé le nez (1640)

(cf. cela lui a haussé le menton)

claquer la porte au nez de qqn (cf. fermer la porte au nez de qqn)

comme le nez au (milieu du) visage (1690)

(cf. sauter aux yeux comme un coup de pied au CUL)

Dieu vous bénisse et vous fasse le nez comme

j'ai la cuisse! (19) (cf. cuisse)

dire qqch au nez de qqn (1640)

(cf. dire qqch à la face de qqn)

donner une vessie de cochon par le nez à qqn (16)

(cf. faire la barbe à qqn 4)

donner du nez en terre (1640)

1. cf. mettre le cul en haut

2. cf. se casser les dents

3. cf. être à cul 1

donner sur le nez à qqn (1690)

(cf. casser la figure à qqn)

être enceinte jusqu'aux trous du nez

(cf. être en cloque jusqu'aux genoux)

faire de son nez (B, 1949)

(cf. avoir les chevilles gonflées)

faire monter la moutarde au nez de qqn (1640) irriter qqn, mettre en colère; (E) to get s.o.'s back up, to make s.o.s blood boil, to get s.o.

up on his ears (US), to get/ put up s.o.s nose, to get under s.o.'s skin

faire qqch au nez (et à la barbe) de qqn (17) (cf. barbe)

faire son nez (19)

(cf. faire une tête longue comme le BRAS)

faire un drôle de nez/ un long nez/ un nez/ un sale nez (19)

(cf. ci-dessus)

faire un pied de nez à qqn

1. cf. faire la barbe à qqn 3 (1640)

2. cf. faire la barbe à qqn 4 (18)

fermer la porte au nez de qqn (1579)

faire mauvais accueil à qqn, refuser de recevoir qqn ; (E) to shut the door in s.o.'s face

fourrer son nez partout (1550)

être indiscret, se mêler de tout; (E) to muscle in on everything, to poke/ shove/ stick/ thrust one's nose into everything, to nose about/ around

frottez votre nez au cul de ces gens-là! (1640) (cf. cul)

il a bon $n e z$, il sent de loin (1640)

il est très prévoyant; (E) he sees things a long way ahead

il a été le premier à la foire du nez (1640) (cf. camus de Lamballe, un pied et demi de nez)

il a la vue plus courte que le nez (1640) il est imprévoyant, irréfléchi; (E) he can't see beyond the end of his nose

il a un nez comme la sébile d'un pressoir (1640) il a le nez rouge d'un ivrogne; (E) he's got a nose to light candles at

il me semble qu'on me pèle le nez (1690) (cf. c'est la BARBE et les cheveux)

il n'a qu'à s'en torcher le nez! (1690) il devra s'en passer; (E) he can shove it up his arse!

il oublierait son nez s'il ne tenait à son visage il est extrêmement distrait; (E) he'd lose his arse if it was loose

il s'est bien refait le nez (1690) il a bien fait son profit; (E) he made quite a nice profit

il tombe sur le dos et se casse le nez (1842) (cf. dos)

j'aime mieux voir vos talons que votre nez! (1640)

(cf. tournez-moi le dos!)

jamais grand nez ne gâta beau visage (1752) la longueur du nez ne nuit pas à la beauté; (E) a long nose never spoiled a handsome face

je vous en sais bon gros nez, chauffez-vous!

(1640)

je vous en sais gré (jeu de mots); (E) I'm most grateful to you!

jeter qqch au nez de qqn (1640)

(cf. jeter qqch à la face de qqn)

jouer de la clarinette sur le bout de son nez (cf. faire la barbe à qqn 4)

jusqu'aux trous du nez (20) (cf. jusqu'au cou)

la moutarde lui monte au nez (1640) la colère le gagne; (E) he's getting his back up, his blood is up, it's getting up his nose

les doigts dans le nez (1912) (cf. doigt)

les joues lui passent le nez (1640) (cf. joue) 
long nez, longue pine (1861)

la taille de l'appendice nasal correspondrait à celle du pénis; (E) a long nose is a lady's liking

lorsqu'on crache en l'air, on ne sait jamais sur quel nez cela retombera

une mauvaise action se retourne souvent contre son auteur; (E) spit not against Heaven, it will fall back on thy face

manger le nez à qqn (19)

(cf. bouffer le nez à qqn)

manquer de nez (1867)

n'être pas habile en affaires; (E) to have no nose for business

mener qqn par le bout du nez (1808)

faire faire tout ce qu'on veut à qqn; (E) to twist s.o. round one's little finger, to have s.o. eating out of one's hand, to lead s.o. by the nose

mener qqn par le nez

1. cf. mener qqn par le bout du nez

2. cf. faire une barbe à qqn (1606)

mettre à qqn le nez dans son caca (1936) reprocher à qqn sa faute; (E) to rub s.o.'s nose into it

mettre le/ son nez dans les affaires d'autrui se mêler des affaires d'autrui; (E) to muscle in on s.o.'s business, to poke one's nose into s.o.'s business

mettre son nez dans le bleu

(cf. prendre sa barbe)

mieux vaut laisser son enfant morveux que de

lui arracher le nez (Montaigne, 1581)

mieux vaut souffrir un mal que de lui appliquer un remède pire; (E) the remedy is often worse that the disease

montrer (le bout de )son nez (1867)

faire une (brève) apparition; (E) to show one's face (somewhere)

mouche ton nez!

(cf. touche à ton cul!)

ne pas lever le nez de (dessus) qqch

s'appliquer à qqch; (E) to keep one's nose to the grindstone

ne pas mettre le nez à la fenêtre/ dehors (17) ne pas sortir, rester chez soi; (E) not to show one's face at the window

ne pas regarder/ voir plus loin que (le bout de) son $n e z$

1. être irréfléchi, imprévoyant (1585);

(E) not to see beyond/ further than the end of one's nose

2. avoir la vue courte (1690); (E) to be short-sighted nez

1. cf. boyau

2. flair, odorat (1572); (E) nose

3. le clitoris (18); (E) clitoris

$n e z$ à camouflets et à nasardes (1690)

individu incapable de se défendre; (E) fellow unable to defend himself

nez à nez (1660)

(cf. face à face)

$n e z$ à piquer des gaufrettes (20)

nez long et pointu; (E) long, pointed nose

nez bourgeonné/ boutonné (1690)

nez d'ivrogne; (E) copper nose, nose to light candles at

nez buriné (1640)

nez marqué par la petite vérole; (E) pock-

marked nose

nez culotté (1872)

(cf. nez bourgeonné)

nez d'as de trèfle (1640)

nez gros et plat; (E) big, flat nose

$n e z$ de betterave (1718)

(cf. nez bourgeonné)

nez de pompette (1640)

(cf. ci-dessus)

nez de rhinocéros (1690)

nez gros et proéminent; (E) big, protruding nose

nez en pied de marmite (1690)

nez large de base et relevé; (E) bottlenose, pug nose

nez en trompette (1745)

nez retroussé; (E) turned up nose

$n e z$ enluminé (1690)

(cf. nez bourgeonné)

$n e z$ où il pleut (1867)

(cf. nez en trompette)

nez qui a coûté cher (à mettre en couleur)

(1867)

(cf. nez bourgeonné)

nez tourné à la friandise (1867)

nez retroussé qui trahirait une complexion amoureuse; (E) turned-up nose supposed to reveal an amorous disposition

nez troussé de peur des crottes (1640) nez court et camus; (E) short, snub nose

parler du nez (17) nasiller; (E) to speak trough one's nose

passer devant (19)/ sous (16) le nez échapper, ne pas obtenir; (E) to slip through one's fingers

pendre au/ devant le nez (13)

être imminent, inévitable; (E) to be

impending, to have it coming 
piquer du nez (20)

(cf. avoir les cils cassés)

pointer son nez (20)

(cf. montrer son nez)

prendre au nez (1640)

(cf. prendre à la gorge)

prendre son nez pour ses fesses (1640)

(cf. se fourrer le doigt dans l'œil jusqu'au COUDE)

prenez-vous par le (bout du) nez! (1640)

vous ne valez pas mieux!; (E) you are no better!

qui coupe son nez dégarnit son visage il ne faut rien faire qui puisse nuire à soimême; (E) one must not do things likely to harm oneself

refaire son nez (17)

faire bonne chère et grossir; (E) to do oneself well and put on weight

regarder qui a le plus beau nez (1640)

se promener en regardant les passants; (E) to mooch about looking at the passers-by

regarder qqn au nez (1640) / sous le nez (1690)

(cf. faire la barbe à qqn $2 \& 4$ )

retomber sur le nez de qqn (1797)

rejaillir sur qqn; (E) to fall back on s.o.

rire au nez de qqn (1690)

se moquer ouvertement de qqn; (E) to laugh

in s.o.'s face

s'arracher le nez du visage (1640)

se faire du tort à soi-même; (E) to shoot oneself in the foot, to cut off one's nose to spite one's face, to cut one's own throat

s'arracher le nez pour faire dépit à son visage (cf. ci-dessus)

s'en mettre plein les trous du nez (1694)

(cf. se caler les amygdales)

s'en mettre un coup dans les trous du nez (1927)

(cf. s'arroser les amygdales)

s'en torcher le nez (1867)

se passer de qqch; (E) to do without sthg

sa bouche dit à ses oreilles que son menton

touche son nez (1842)

(cf. bouche)

saigner du nez

1. cf. avoir un cœur de citrouille 2 (1690)

2. ne pas tenir sa promesse (1640); (E) not to keep one's promise

se bouffer le nez (1857)

se disputer violemment; (E) to jump down

each other's throat

se casser le nez (19)

(cf. prendre sa barbe) se laisser mener par le nez (1559)/ par le bout

du nez (1808)

manquer de caractère; $(\mathrm{E})$ to let oneself be led by the nose

se laisser mener par le nez comme un buffle

(1690)

se faire rouler; (E) to let oneself be done in the eye

se laver le bout du nez

faire une toilette très sommaire; (E) to give oneself a cat's lick

se manger le bout du nez (1857)

(cf. se bouffer le nez)

se moucher plus haut que son nez

(cf. péter plus haut que son cul)

se noircir le nez (19)

(cf. prendre sa barbe)

se passer qqch sous le nez (1883)

1. cf. se mettre qqch sous la dent

2. boire qqch; (E) to have a drink

se peindre (1867)/ piquer (1872) le nez

(cf. prendre sa barbe)

se promener le nez au vent (19)

être à la recherche d'occasions; (E) to nose

after/ for opportunities

se salir le nez (1867)

(cf. prendre sa barbe)

sentir à plein nez (16)

dégager de mauvaises odeurs; (E) to get right up one's nose

sentir du nez (1640)

(cf. avoir de l'estomac 2)

si le nez de Cléopâtre eût été plus court, toute la

face du monde aurait changé (Pascal, 1670)

le destin des hommes dépend de peu de choses; (E) if Cleopatra's nose had been shorter, the whole face of the world would have been changed

si on lui pinçait/ pressait/ tordait le nez, il en sortirait du lait (17)

il est jeune, sans expérience; (E) he's still wet behind the ears, he hasn't cut his teeth yet

sortir par les trous du nez (20)

(cf.. sortir du cul)

tenir son nez propre (1959)

ne pas parler à tort et à travers; (E) not to

talk through (the back of) one's neck

tirer les vers du nez à qqn (15)

questionner qqn adroitement; (E) to pick s.o.'s brains

tomber nez à nez avec qqn

rencontrer qqn par hasard; (E) to meet s.o.

head on

tomber sur le dos et se casser le nez (1842)

(cf. avoir des mains de beurre) 
tordre le nez sur qqch (20)

1. cf. faire qqch à contrecœur

2. cf. mettre qqch au trou de son cul visage qui n'a point de nez (1640)

(cf. bas du dos)

votre nez branle/ remue! (1842)

vous mentez!; (E) you lie in your teeth/ throat!

vous me pelez le nez! (1640)

(cf. la barbe!)

\section{NOMBRIL}

être décolletée jusqu'au nombril (20) avoir un décolleté très profond; (E) to be showing a lot of cleavage

faire une pirouette sur le nombril (1864)

(cf. mettre chair vive en chair vive)

ne s'intéresser qu'à son nombril

être égoïste, ne penser qu'à soi; (E) to be selfish, self-centred

se croire le nombril du monde, se prendre pour

le nombril du monde (20)

(cf. ne pas se moucher du coude 1)

se regarder le nombril (20)

être très fier de soi; (E) to be very pleased with oneself

trinquer du nombril (1850)

(cf. manger de la chair crue; mettre chair vive en chair vive)

CEIL

à l'oil

1. au jugé, sans mesurer (16); (E) by (the)

eye, by rock of eye and rule of thumb

2. à crédit (1827); (E) on the arm (US)

3. gratuitement (1900); (E) free, gratis and for nothing

à xil ou nez malade, ne touche que du coude (17)

(cf. coude)

à vue d'œil (1562)

1. cf. à l'œil 1

2. de façon visible, nettement; (E) visibly, clearly

à yeux clos (1690)

aveuglément, en toute confiance; (E) blindly, confidently

aimer qqn plus que ses yeux (1690)

(cf. aimer qqn comme ses petits boyaux)

au doigt et à l'oeil (17)

(cf. doigt)

au premier coup d'oil

d'emblée; (E) with half an eye

aussi peu qu'il pourrait en tenir dans mon oeil (1690)

(cf. pas plus que de beurre au cul) autant vous en pend à l'œil (1690)

la même chose peut vous arriver; (E) the same may happen to you!

aux yeux de

de l'avis de, du point de vue de; (E) in the eyes of

avoir (qqn) à l'oil (1798)

surveiller qqn de près; (E) to keep an/ one's

eye on s.o., to eyeball s.o.

avoir bon pied bon oeil (17)

1. cf. avoir de la dent

2. être sur ses gardes, être vigilant; (E) to be sharp-eyed

avoir bonne mine et mauvais yeux (1606) avoir du chagrin; (E) to be grieved

avoir de la merde dans les yeux (20) ne pas voir l'évidence; (E) to miss the obvious

avoir des yeux culottés (1872)

avoir les yeux rougis par l'alcool; (E) to have cranberry-eyes (US)

avoir des yeux d'argus

être aux aguets pour tout voir; (E) to have an eye for everything, to have eyes at the back of one's head

avoir des yeux dans le dos (20) (cf. dos)

avoir des yeux de gazelle (19) avoir des yeux allongés et pleins de douceur (en parlant d'une femme); (E) to have almond-shaped eyes, to be doe-eyed

avoir des yeux de lynx

1. pénétrer les desseins d'autrui (1690);

(E) to see through s.o.

2. avoir une vue perçante $(18) ;(\mathrm{E})$ to be keen-eyed/ eagle-eyed (US)

avoir des yeux de lapin blanc (1867) avoir des yeux rouges avec des cils blancs; (E) to have red eyes and white eyelashes avoir des yeux de percerette (1894) avoir de petits yeux perçants; (E) to have little, sharp eyes

avoir des yeux en boules de loto (1851) avoir des yeux globuleux; (E) to have goggleeyes/ goo-goo eyes, to have eyes like cod's ballocks

avoir des yeux en boutons de bottine (20) avoir de petits yeux ronds; (E) to have little, round eyes

avoir des yeux en trou de bite (20)/ de vrille avoir de tout petits yeux; (E) to have gimlet eyes

avoir l'ail (1867)

(cf. avoir bon pied bon œil 2) 
avoir l'oil à qqch veiller à qqch; (E) to see to sthg

avoir l'œil à tout (1470)

(cf. avoir des yeux d'argus)

avoir l'oil américain

1. voir clair, voir juste (1857); (E) to have a

sharp eye

2. avoir le regard séducteur (1872); (E) to

have an enticing look

avoir l'cil au bois (1690)

veiller à ses affaires, se méfier; (E) to keep a

close watch on one's business

avoir l'œil au guet (1690)/ aux aguets (19)

se montrer très vigilant; (E) to keep one's

best eye peeled, to keep one's weather-eye open (US), to have (all) one's eyes about one, to have no butter in one's eyes, to keep one's eyes open/ peeled/ skinned, to keep one's eyes and ears open

avoir l'oeil au vent (15)

ne pas baisser le regard; (E) not to look down

avoir l'œil sur qqch/ qqn (1521)

1. cf. avoir l'œil à qqch

2. cf. avoir qqn à o'œil

avoir la larme à l'oeil (15)

1. cf. avoir le cœur serré

2. avoir envie de pleurer; (E) to feel like crying

avoir la Marianne dans l'oil (19)

(cf. avoir sa barbe)

avoir le compas dans l'œil (18)

apprécier avec exactitude; (E) to have an accurate eye

avoir le coup d'oil

(cf. avoir l'œil américain 1)

avoir les larmes aux yeux (17)

(cf. avoir la larme à l'œil)

avoir les yeux bordés d'anchois (1833)/ de

(maigre de) jambon (1894)

avoir le bord des paupières rouge et enflammé; (E) to have red, inflamed eyelids

avoir les yeux en compote (1690)

avoir les yeux pochés; (E) to have bunged up eyes

avoir les yeux hors de la tête (19)

(cf. avoir le cœur gros 1)

avoir les yeux mâchés (1894)

(cf. avoir les yeux en compote)

avoir les yeux plus grands que le ventre

1. se servir au-delà de ce que l'on peut

manger (1580); (E) to have one's eyes bigger

than one's belly/ stomach

2. surestimer ses capacités, avoir des ambitions au-delà de ses moyens (1690); (E)

to bite off more than one can chew

avoir les yeux qui pleurent à la porte d'une

culotte (1864)

(cf. avoir la cuisse facile)

avoir plus grands yeux que panse (1690)

(cf. avoir les yeux plus grands que le ventre 2)

avoir toujours la larme à l'œil (19)

pleurer facilement; (E) to be easily moved to tears

avoir un bon coup d'œil

1. cf. avoir l'œil américain 1

2. avoir un jugement sûr; (E) to have good judgement

avoir un $x i l$ à Paris et l'autre à Pontoise (1868)

loucher; (E) to have one eye looking at you and the other looking for you, to be boss-

eyed/ cock-eyed/ cross-eyed/swivel-eyed/

wall-eyed, to have calf eyes/ cock eyes/ gimlet eyes/ swivel eyes/ $\mathrm{x}$-eyes

avoir un oil au beurre noir (1835)

avoir un œil tuméfié; (E) to have an eye in

(full) mourning, to have fallen down and

trod upon one's eye

avoir un $œ i l$ aux champs et l'autre à la ville (17) veiller à plusieurs choses à la fois; (E) to see to several things at the same time

avoir un oeil qui dit merde/ zut à l'autre (1878)

(cf. avoir un œeil à Paris et l'autre à Pontoise)

avoir une coquetterie dans l'oil (20) être atteint(e) d'un (très) léger strabisme;

(E) to have a slight squint

avoir une paille dans l'œil (1690) avoir un trouble de la vue; (E) to have eyetrouble

brûler les yeux à qqn (1690)

faire en présence de qqn une chose qui lui est désagréable; (E) to act disgracefully in s.o.'s presence

ça crève les yeux! (1640)

(cf. cela se voit au DOIGT et à l'œil)

ça lui a dessillé/ ouvert les yeux cela a été une révélation pour lui; (E) it made him open his eyes, it was an eyeopener for him, the scales have fallen from his eyes

ça lui pend à l'oil (12)

(cf. ça lui pend au cul)

ça vaut le coup d'oil

c'est beau à voir, c'est remarquable; (E) it's a sight to see

c'est de la poudre aux yeux!

ce sont des artifices pour tromper les apparences; (E) that's all my eye ! 
cela saute aux yeux! (17)

(cf. cela se voit au DOIGT et à l'ail)

cela se voit au doigt et à l'œil

$$
\text { (cf. doigt) }
$$

chaque fois qu'il me tombe un oeil très rarement; $(\mathrm{E})$ once in a blue moon

chier (17))/ chigner (1867) des yeux pleurer; (E) to pipe an/ one's eye, to put (the) finger in (the) eye

chier sur l'oil à qqn (1867)

(cf. faire la barbe à qqn 4)

choisir de l'œil (1640)

regarder avec intention; (E) to look purposely at

clin d'oil (15)

mouvement de paupière; (E) wink

commencer d'avoir de la poudre dans les yeux (1640)

(cf. avoir les cils cassés)

coup d'eil

1. regard rapide (1668); (E) glance, look

2. panorama, vue (19); (E) sight, view

coûter les yeux de la tête (1867)

(cf. coûter la peau du cul)

couver des yeux (1649)

regarder avec complaisance ou convoitise;

(E) to look fondly or longingly at crever l'ail

1. cf. botter le cul (1867)

2. cf. aller au cul 2 (18)

crever l'oeil au/ du diable (1842)

1. réussir malgré les envieux; (E) to succeed in spite of envious people

2. faire le bien malgré les ingrats; (E) to do good in spite of ungrateful people

crever les yeux (15)

(cf. sauter aux yeux comme un coup de pied au CUL)

dévorer / manger des yeux

regarder avec avidité ou insistance; (E) to

devour with one's eyes, to eye greedily, to wolf-eye

donner dans l'œil à/ de qqn (1755)

1. donner envie à qqn; (E) to make s.o. envious

2. plaire à qqn; (E) to take one's/ s.o.'s fancy

donner dans les yeux (1640)

inspirer du désir, de l'amour; (E) to inspire desire, love

donner un coup d' $œ$ il à/ sur qqch (1690)

examiner, vérifier qqch; (E) to cast an eyel run one's eye over sthg

du premier coup d'cil

(cf. au premier coup d'œil) en avoir par-dessus les yeux (17)

(cf. en avoir par-dessus les épaules 2)

en mettre plein les yeux à qqn

éblouir qqn, tenter d'impressionner qqn;

(E) to throw dust in s.o.'s eyes

en un cil d'œil (16)

(cf. cil)

en un clin d'œil (1530)

(cf. en un CIL d'œil)

entre quatre-z-yeux (1740)

en privé, sans témoin; (E) eyeball to eyeball

épouser une femme pour ses beaux yeux préférer la beauté à la dot; (E) to marry a pretty face

est-ce que tu as tes yeux en poche? (19) tu ne vois donc rien!; (E) where are your eyes?!

être dans la paille jusqu'aux yeux (1690) vivre dans l'opulence; (E) to be in affluence

être de la société du doigt dans l'œil (1872) (cf. doigt)

être enceinte jusqu'aux yeux (19)

(cf. être en cloque jusqu'aux genoux)

être prêts à se sauter aux yeux être sur le point de se battre; (E) to be about to fight

être servi au doigt et à l'oxil (1690) (cf. doigt)

être tout yeux, tout oreilles (17) être très attentif; (E) to be all ears, to listen with all one's ears, to be all eyes, to keep one's eyes and ears open

être très sur l'oeil être très sévère, très strict; $(\mathrm{E})$ to be very formal, severe

faire de l'œil à qqn (1665) lancer des regards séducteurs; (E) to give s.o. the (glad) eye, to have eyes for s.o., to make (goo-goo/ sheep's) eyes at s.o.

faire des petits yeux (15) (cf. avoir les cils cassés)

faire des yeux de carpe frite (1745)/ pamée regarder amoureusement; (E) to turn upon one's eyes like a duck in a thunderstorm

faire des yeux de merlan frit (1888) (cf. ci-dessus)

faire des yeux en coulisse à qqn (1834) (cf. faire de l'œil à qqn)

faire le bon oeil à qqn (19) (cf. accueillir à bras ouverts)

faire les gros yeux à qqn (18) réprimander qqn du regard; (E) to look reprovingly at s.o. 
faire les yeux blancs

1. cf. avoir les DOIGTS de pied en bouquets de violettes (1864)

2. s'évanouir; (E) to show the white of one's eyes, to turn up (the whites of) one's eyes

faire les yeux doux à qqn (1680)

(cf. faire de l'œil à qqn)

faire qqch les yeux fermés (19)

1. cf. les DOIGTS dans le nez

2. cf. à yeux clos

faire qqch pour les beaux yeux de qqn (1640)

faire qqch de façon désintéressée; (E) to do sthg for s.o.'s sake

faire qqch sous les yeux de qqn

(cf. faire qqch à la barbe de qqn)

faire toucher une vérité au doigt et à l'œil (1690) (cf. doigt)

fermer l'œil (19)

1. cf. plier les cils

2. cf. raidir le jarret 2

fermer les yeux

1. cf. plier les cils

2. cf. raidir le jarret 2 (1721)

fermer les yeux à qqch (1640)

refuser de considérer qqch; (E) to close/ shut one's eyes to sthg

fermer les yeux à qqn (1550)

assister qqn dans ses derniers moments

(E) to close s.o.'s eyes

fermer les yeux sur qqch (1644)

tolérer qqch; (E) to shut one's eyes to sthg, to turn a blind eye to sthg

fille qui a les yeux tournés à la fricassée (1894)

fille d'un grand tempérament; (E) hottempered girl

frais comme l'ail (1868)

en pleine forme; $(\mathrm{E})$ at the top of one's form

il a les yeux riants comme une truite brûlée

(1640)

il a une très mauvaise vue; (E) he has a very poor sight

il a tant pleuré d'un oil que l'autre ne s'en

ressent point (1640)

il n'a pas beaucoup de regret; (E) he hasn't much regret

il fallait qu'il eût les yeux au derrière (1690) (cf. derrière)

il faut chercher une femme avec les oreilles

plutôt qu'avec les yeux (1842)

une bonne réputation importe plus que la

beauté; (E) choose a wife rather by your ear than your eye

il n'est pour voir que l'oeil du maître (La

Fontaine, 1668)

rien ne vaut la surveillance du maître;
(E) no eye like the eye of the master, one eye of the master is worth four of the servants', the eye of the master will do more work than both his hands, the master's eye makes the horse fat

il n'y avait que quatre yeux (1690)

l'affaire était privée, secrète; (E) it was a private/ secret affair

il ne faut toucher aux yeux que du coude (1640) (cf. coude)

il vaut mieux se fier à ses yeux qu'à ses oreilles (1842)

il vaut mieux vérifier par soi-même; $(\mathrm{E})$ it is better to check by oneself

jeter de la poudre aux yeux de qqn

1. cf. casser BRAS et jambes à qqn (1690)

2. cf. faire une barbe à qqn (17)

3. cf. en mettre plein les yeux à qqn (17)

jeter l'œil sur qqch (1640)

(cf. donner un coup d'œil à)

jeter le mauvais oeil à qqn (19)

porter malheur, jeter un sort; (E) to point a bone at s.o.

jeter les yeux sur qqch/ qqn (16) regarder qqch/ qqn; (E) to set eyes on sthg/ s.o.

jeter un coup d'oeil à/ sur qqch

(cf. donner un coup d'œil à)

jusqu'aux yeux (17)

(cf. jusqu'au cou)

l'amour a besoin des yeux comme la pensée a

besoin de la mémoire $\left(\mathrm{M}^{\mathrm{me}}\right.$ Necker, 1798)

(cf. loin des yeux, loin du CEEUR)

l'avoir dans l'œil

(cf. l'avoir dans le cul 1)

l'oeil du fermier vaut fumier (1672) (cf. il n'est pour voir que l'œil du maître)

l'ail du maître engraisse le cheval (1568) (cf. ci-dessus)

la corniche lui tombe dans l'œil (18)

il a une veine de cocu (jeu de mots: corniche = corne); (E) he has the devil's own luck

le mal a l'oeil, il faut le panser avec le coude (1842)

(cf. il ne faut toucher aux yeux que du COUDE)

le petit homme lui a jeté du sable dans les yeux (1690)

il a sommeil; (E) the sandman has gone by

les écailles lui tombent des yeux (17)

(cf. ça lui a ouvert les yeux)

les yeux sont le miroir de l'âme (17)

le regard donne une image du caractère;

(E) the face is the index of the heart, the

heart's letter is read in the eyes 
lever les yeux au ciel

montrer de l'impatience, de l'irritation;

(E) to cast one's eyes up to heaven

loin des yeux, loin du cour (1610)

(cf. cœur)

marcher au doigt et à l'œil (19)

(cf. doigt)

mauvais oil (1611)

maléfice; (E) evil spell

mener qqn au doigt et à l'oil (19)

(cf. doigt)

mon oil! (1861)

1. cf. mon cul!

2. exclamation de scepticisme; (E) my eye!, my (left) foot!

n'avoir d'yeux que pour qqn (1631)

accorder une attention exclusive à qqn;

(E) to have eyes for nobody but...

n'avoir pas froid aux yeux (1826)

1. cf. avoir du CEEUR au ventre

2. cf. avoir de l'estomac 2

n'avoir (plus) que ses yeux pour pleurer (18) avoir tout perdu; (E) to be left only one's eyes to weep with

ne dormir que d'un oil (1704)

1. avoir le sommeil léger; (E) to be a light sleeper

2. demeurer sur ses gardes; (E) to sleep with one eye open, to keep on one's toes (US)

ne pas avoir les yeux dans sa poche/ en poche (1859)

(cf. avoir l'œil au guet)

ne pas avoir les yeux en face des trous (1925)

1. cf. avoir les bras rompus

2. cf. avoir la cervelle aux talons

ne pas en croire ses yeux (13)

(cf. demeurer bouche bée)

ne pas fermer l'ail (1688)

passer une nuit blanche; (E) not to sleep a wink all night

nourris un corbeau, il te crèvera l'œil/ les yeux (16)

les méchants rendent le bien pour le mal;

(E) breed up a crow and he will tear out your eyes

obéir au doigt et à l'œil (1812)

(cf. marcher au DOIGT et à l'œil)

observer qqch/ qqn du coin de l'oeil (1640) regarder subrepticement; (E) to look at sthg/ s.o. out of the corner of one's eye/ out of the tail of one's eye

oil (1752)

l'anus; (E) arse-hole, asshole (US), eye, round mouth ceil au beurre noir (1835)/ à la coque (20) œil tuméfié; (E) black eye, eye in (full) mourning

ceil de bronze (1930)

(cf. œil)

oeil en tirelire (1867)

regard séducteur, l'œil mi-clos; (E) enticing look

oil marécageux (1872)

(cf. ci-dessus)

ceil pour eil, dent pour dent (1690) (cf. dent)

ceil un autre ceil voit et non soi tout homme se méconnaît; (E) man does not know himself

on connaît à ses yeux que sa tête n'est pas cuite (1640)

il a l'air tracassé; (E) his head is full of bees, he's eating his heart out

on se voit d'un autre $2 i l$ qu'on ne voit son

prochain (La Fontaine, 1668)

(cf. voir la paille dans l'œil de son voisin...)

orgueil n'a pas bon ceil (1611)

l'orgueil est mauvais conseiller; (E) pride is not a wise counsellor

ouvrir de grands yeux

(cf. demeurer bouche bée)

ouvrir des yeux comme des soucoupes (20)

(cf. ci-dessus)

ouvrir l'œil (et le bon) (1867)

(cf. avoir l'œil au guet)

ouvrir les yeux à qqn (sur qqch) (19)

détromper qqn; (E) to open s.o.'s eyes (to sthg)

ouvrir les yeux grands comme une salière (1640) (cf. demeurer bouche bée)

pas plus que dans mon oeil (1808)

(cf. pas plus que de beurre au cul)

passer la mouche devant les yeux de qqn (1640) (cf. faire monter la moutarde au nez à qqn)

payer les yeux de la tête payer très/ trop cher; (E) to pay an arm and a leg, to pay through the nose pendre à l'oeil (12)

(cf. pendre au nez)

pisser de l'œil (19)

(cf. chier des yeux)

pleurer d'un oeil et rire de l'autre rire et pleurer à la fois; (E) to laugh and cry at the same time

pocher les yeux à qqn (17)

tuméfier les yeux à coups de poing; (E) to black s.o.'s eyes, to give s.o. a black eye, to put s.o.'s eye in a sling, to sling s.o. one in the eye, to bung up s.o.'s eyes 
qu'il lui passe une mouche devant les yeux, il change, il se dédit (1690)

un rien le fait changer d'avis; (E) he is of a fickle disposition

quand il lui tombe un oeil (1883)

jamais; (E) when pigs will fly

quart d'eil (1791)

commissaire de police; (E) police super-

intendent

quatre yeux voient plus que deux (1680)

mieux vaut vérifier deux fois; (E) four eyes

see more than two, two eyes see more than one

regarder avec des yeux ronds

(cf. demeurer bouche bée)

regarder qqch à l'œil nu (1690)

observer sans l'aide d'instruments; (E) to

observe with the naked eye

regarder qqn dans le blanc des yeux/ dans les yeux

(cf. regarder qqn bien en face)

regarder qqn d'un cil noir

regarder qqn sans aménité; (E) to give s.o. a black look

regarder qqn du coin de l'œil

(cf. observer qqn du coin de l'œil)

regarder qqn entre (les) deux yeux (1690)

(cf. regarder qqn bien en face)

risquer un oil

jeter un regard furtif; (E) to peep out

rougir jusqu'au blanc des yeux (18)

(cf. rougir jusqu'à la racine des cheveux)

s'en battre l'œil (1666)

(cf. se torcher le cul de qqch)

s'en mettre jusqu'aux yeux/ par-dessus les yeux (17)

(cf. se caler les amygdales)

sans lever les yeux

(cf. d'arrache-pied)

sauter aux yeux (17)

(cf. sauter aux yeux comme un coup de pied au CUL)

se crever les yeux

s'abîmer la vue (à lire, à coudre, etc.); (E) to ruin one's eyes

se fourrer dans l'ail (1866)

(cf. se fourrer le doigt dans l'œil jusqu'au COUDE)

se fourrer le doigt dans l'œil (1864)

(cf. ci-dessus)

se fourrer le doigt dans l'œil jusqu'au coude (1867)

(cf. coude)

se laver les yeux (1867)

boire un verre de vin blanc au lever; (E) to have a glass of white wine when getting up se manger le blanc des yeux

1. cf. se bouffer le nez (1640)

2. se regarder avec colère (1867); (E) to look

daggers at one another

se mettre le doigt dans l'ail (jusqu'au coude)

(cf. coude)

se regarder dans le blanc des yeux (19)

s'ennuyer en compagnie de qqn, n'avoir rien

à se dire; (E) to feel bored in s.o.'s company

having nothing to talk about

se rincer l'œil (1883)

regarder avec grand plaisir (généralement

érotique); (E) to feast one's eyes on, to get/

have/ take an eyeful of, to nearly lose one's

eyesight

sortir par les yeux (1771)

(cf. sortir du cul)

soufflez-moi dans l'œil! (1640)

je veux savoir si vous avez bu; (E) I want to

know if you've been drinking

suivre qqn de l'oil (1640)/ des yeux

ne pas perdre qqn de vue; (E) to keep s.o. in sight

sur les défauts d'autrui l'homme a des yeux

perçants (Destouches, 1764)

(cf. voir la paille dans l'œil de son pro-

chain...)

tape à l'oil

1. individu borgne (1872); (E) one-eyed

person

2. frime, esbroufe (19); (E) eyewash

taper dans l'œil à/ de qqn (1867)

(cf. donner dans l'œil à qqn)

taper de l'oil (1750)

(cf. être dans les bras de Morphée)

tel a de beaux yeux à la tête qui n'en verra pas la fête (1640)

malgré son apparente bonne santé, il ne vivra pas longtemps; (E) he won't live long despite his apparent good health

tel a de beaux yeux, qui ne voit goutte (1456)

(cf. la barbe ne fait pas l'homme)

tenir à qqch/ qqn comme à la prunelle de ses yeux (1306)

(cf. aimer comme ses petits boyaux)

tenir à l'œil (1798)

(cf. avoir à l'œil)

tirer l'œil (1872)

attirer l'attention; (E) to catch/ draw/ strike

the eye

tortiller de l'oil (1867)

1. cf. faire les yeux blancs 2

2. cf. raidir le jarret 2 
toucher au doigt et à l'oeil (1640)

$$
\text { (cf. doigt) }
$$

tourner de l'oil (1867)

1. cf. plier les cils

2. cf. faire les yeux blancs

3. cf. raidir le jarret 2

tourner l'œil (1894)

(cf. tourner de l'œil $2 \& 3$ )

tourner les yeux à la tête (1640)

(cf. faire les yeux blancs 2)

tout-à-l'oil (19)

député, parlementaire; (E) Member of Parliament

trouver grâce aux yeux de qqn (16)

bénéficier de l'indulgence de; (E) to find

favour in s.o.'s eyes

un bon avis vaut un oeil dans la main (1842) (cf. main)

un qui n'a point de blanc en l'œil (1640)

le diable; (E) the devil

voir de/ d'un bon ail (16)

1. cf. faire le bon œil

2. approuver, considérer avec faveur; (E) to

look approvingly on

voir de/ d'un mauvais ail (1558)

désapprouver, voir avec déplaisir; (E) to look disapprovingly on

voir qqch du même ail

avoir la même opinion sur qqch; (E) to see eye to eye with s.o.

voir la paille dans l'aeil de son prochain et pas la poutre dans le sien (Matthieu, 7,3-5)

remarquer les défauts d'autrui et pas les siens propres; (E) to see the mote in one's

brother's eye but not the beam in one's own

ONGLES

à belles dents, à belles ongles (1640)

(cf. dent)

attaquer qqn du bec et des ongles (17) s'acharner sur qqn; (E) to go for s.o. tooth and nail

avoir bec et ongles (1606)

être capable de bien se défendre; (E) to be able to defend oneself

avoir du sang aux ongles (1640)

(cf. avoir du CCEUR au ventre)

avoir les ongles crochus (1842)

(cf. aimer la manche plus que le bras)

avoir les ongles fleuris (1842)

1. avoir les ongles marqués de petites taches;

(E) to have spotted nails

2. avoir l'habitude de mentir; (E) to be an habitual liar

avoir les ongles pâles

(cf. avoir des bras en saindoux) connaître sur le bout des ongles

(cf. connaitre sur le bout des doigts)

couper les ongles à qqn (17)

1. cf. tenir la main haute à qqn

2. limiter le pouvoir de qqn; (E) to cut s.o.'s claws

doigt qui n'a point d'ongle (1640) (cf. boyau)

donner sur les ongles à qqn

(cf. prendre qqn aux cheveux)

faire rubis sur l'ongle (1640)

1. boire la dernière goutte du verre (versée sur l'ongle); (E) to drain one's glass to the last drop

2. faire une chose à fond; (E) to do sthg thoroughly

3. satisfaire une femme sexuellement; (E) to gratify a women sexually

faire un pet à vingt ongles (1690)

enfanter; (E) to piss bones, to make feet for children's stockings, to be cured of tympany with two heels

jusqu'au bout des ongles (1694)

(cf. jusqu'au bout des doigts)

ne croître que par les cheveux et par les ongles (cf. cheveu)

ongles bons à tirer la chair du pot (1690) ongles longs et sales; (E) long, dirty nails

ongles de velours (1690)

(cf. ci-dessus)

ongles en (demi) deuil (1841)

ongles malpropres; (E) nails in mourning

payer rubis sur l'ongle (1668) payer exactement; (E) to pay on the nail

qui tard arrive à bien, aux ongles le tient (13) on s'accroche d'autant plus à un bien qu'on a mis du temps à acquérir; (E) the longer it takes to acquire property, the more it is valued

rogner les ongles (de près) à qqn (14)

(cf. tenir la main haute à qqn)

savoir sur le bout des ongles

(cf. connaitre sur le bout des doigts)

se ronger les ongles (1580) montrer de l'impatience, de la nervosité;

(E) to gnaw one's fingers/ knuckles, to bite one's nails

\section{OREILLE}

âne à courtes oreilles (qui ne mange point de chardon) (1640)

(cf. cervelle à double rebras)

autant vous pend à l'oreille

(cf. autant vous pend à l'œil)

avoir de l'oreille (1690)

avoir une juste perception des sons; (E) to have a good ear, to have an ear for 
avoir fait une oreille à un enfant (1690) avoir eu une relation avec la mère; (E) to have had intercourse with the mother of a child

avoir l'oreille basse

1. cf. avoir un pied de nez 2 (17)

2. cf. mort dans le dos (1896)

avoir l'oreille de qqn (16)

être écouté de qqn; (E) to have s.o.'s ear

avoir l'oreille fine

avoir une bonne ouie; (E) to have a keen

ear/ sharp ears

avoir la puce à l'oreille (14)

1. cf. être en cervelle

2. avoir l'attention éveillée, se douter de qqch; (E) to smell a rat

avoir le bouquet sur l'oreille (1640)

être à marier $(\mathrm{f})$; $(\mathrm{E})$ to be marriageable $(\mathrm{f})$

avoir les oreilles (battues et) rebattues (18)

être las d'entendre toujours la même chose;

(E) to be sick of hearing the same thing over and over again

avoir les oreilles pendantes (1690)

(cf. avoir un pied de nez 2)

avoir une bonne oreille

(cf. avoir de l'oreille)

baisser l'oreille (1690)

1. cf. avoir un pied de nez 2

2. être découragé; (E) to be downhearted, to be down in the mouth

boucher ses oreilles (1690)

refuser d'écouter; (E) to give a cold ear to, to turn a deaf ear on, to close one's ears to

casser les oreilles à qqn (19)

fatiguer qqn par le bruit ou la parole; (E) to chew/ talk s.o.'s ear off, to annoy s.o.'s head, to talk s.o.'s head off

cela choque l'oreille (1640)

cela ne sonne pas bien; (E) that doesn't sound well

chatouiller les oreilles à qqn (17)

(cf. faire monter la moutarde au nez à qqn)

confier qqch dans le tuyau de l'oreille (19) confier en secret; (E) to drop / whisper sthg in (to) s.os.'s ear

corner qqch aux oreilles de qqn (1867) répéter qqch jusqu'à désagrément; (E) to dig sthg into s.o.'s ears

de bouche à oreille (19)

(cf. bouche)

dire deux mots à l'oreille de qqn

(cf. prendre qqn aux cheveux)

donner sur l'oreille (1640)

enivrer; (E) to make s.o. drunk donner sur les oreilles à qqn (1690)

(cf. battre les joues à qqn)

dormir sur ses deux oreilles (19)

1. avoir le sommeil profond; (E) to sleep

soundly

2. n'avoir point d'inquiétude; (E) to have one's mind at ease

dresser l'oreille

1. prêter attention (12); (E) to cock/ prick

up/ strain one's ears

2. avoir une érection (17); (E) to have a bone

on (US), to have a nose-swelling/ a toothache

dresser les oreilles (1690)

s'enorgueillir d'un succès; (E) to pride

oneself of a success

échauffer les oreilles de qqn (17)

(cf. faire monter la moutarde au nez de qqn)

écorcher l'oreille / les oreilles

être désagréable à l'ouĩe; (E) to grate on the ear

elle s'écoute parler, elle a la bouche près des

oreilles (1640)

(cf. bouche)

en avoir par-dessus les oreilles (18)

(cf. en avoir plein le cul 2)

entrer par une oreille et sortir par l'autre (1640)

1. ne pas rester en mémoire; (E) to go in at

one ear and out at the other

2. laisser indifférent; (E) to go in at one ear and out at the other

être dur d'oreille (17)

être un peu sourd; (E) to be hard of hearing

être toujours pendu aux oreilles de qqn (1690)

harceler qqn de paroles; (E) to talk s.o.'s

ears/ head off

être tout oreilles (17)

écouter attentivement; (E) to be all ears, to

listen with all one's ears/ with both ears, to

pin one's ears back

être tout yeux tout oreilles (17)

(cf. œil)

faire la sourde oreille (15)

1. cf. boucher ses oreilles

2. ne pas donner suite; (E) to give a cold/

deaf ear to

fendre l'oreille à qqn (1872)

mettre qqn à la retraite; (E) to retire s.o.

fermer l'oreille à (1640)

(cf. se boucher les oreilles)

frotter les oreilles à qqn (1668)

(cf. battre les joues à qqn)

gagner l'oreille de qqn (1559)

se faire entendre de qqn, gagner la confiance

de qqn; (E) to bend s.o.s ear 
il a du coton dans les oreilles (1640) il fait le sourd; (E) he pretends to be deaf il a les oreilles bien longues (1640) 1. il est stupide; (E) he was on the wrong side of the door/ hedge when the brains were given away/ handed out, he has nothing between the ears, he's dead from the neck up 2. il est épuisé par l'acte charnel; (E) he is exhausted from repeated coition

il a rapporté ses deux oreilles (1640) il est revenu sain et sauf; (E) he came out of it/ he got by with a whole skin, he saved his neck/ skin

il en a jusqu'aux oreilles (1640)

il est fort engagé; (E) he is very much committed

il faut chercher une femme avec les oreilles

plutôt qu'avec les yeux (1842) (cf. œil)

il s'y est fourré jusqu'aux oreilles (1640)

(cf. il en a jusqu'aux oreilles)

il vaut mieux se fier à ses yeux qu'à ses oreilles (1842)

(cf. œil)

je me ferais couper les oreilles pour... je serais prêt à tout faire pour...; (E) I'd give my ears for it/ my life's blood to

jusqu'aux oreilles (17) (cf. jusqu'au cou)

l'argent lui fait ouvrir/ prêter les oreilles (17) il est corruptible; (E) he is corruptible

l'oreille est le chemin du cour (cf. cœur)

laisser passer le bout de l'oreille (19) se trahir, dévoiler ses intentions; (E) to show the cloven hoof

les femmes sont plus chastes des oreilles que de tout le reste du corps (Molière, 1663) (cf. corps)

les murs ont des oreilles (1690) il n'y a pas de secret qui ne puisse être découvert; (E) walls have ears, fields have eyes and hedges ears

les oreilles me cornent (1640) on parle de moi; (E) my ears are burning/ tingling

les oreilles ont dû lui tinter (1842) on a beaucoup parlé de lui; (E) his ears must have burned/ must have been tingling

les petits enfants ont l'oreille fine les enfants entendent tout; (E) little pitchers have long ears

lever l'oreille (16)/ les oreilles (1861)

(cf. dresser l'oreille 2) mettre la puce à l'oreille de qqn (1867) éveiller les soupçons de qqn; (E) to put a bug into s.o.'s ear (US)

mettre la tête entre les deux oreilles à qqn (cf. prendre qqn aux cheveux)

montrer le bout de l'oreille (19) (cf. laisser passer le bout de l'oreille)

n'avoir pas d'oreille (1690) n'avoir aucune aptitude musicale; (E) to have no ear for music, to have tin ears n'avoir par l'oreille musicale (1547) (cf. ci-dessus)

n'écouter que d'une oreille (16) écouter distraitement; (E) to listen with one ear only/ with only half an ear, to have cloth ears

ne pas en croire ses oreilles douter de ce qu'on entend; (E) to hardly trust one's own ears

ne pas l'entendre de cette oreille (1828) ne pas être d'accord; (E) not to agree to

ne pas se faire tirer l'oreille (1562) acquiescer/ accepter d'emblée; (E) not to have to be asked twice

ne pas tomber dans l'oreille d'un sourd (19) n'être pas perdu pour tout le monde; (E) not to be lost for everybody

partir l'oreille basse (cf. se retirer le dos rond)

pendants d'oreilles (16)

(cf. lèche-cul)

pendre à l'oreille/ aux oreilles (18) (cf. pendre au nez)

prendre son cul par l'oreille (1894) (cf. cul)

prêter l'oreille à (13) écouter; (E) to give/ lend an ear to, to lend one's ear to

prêter l'oreille au scandale être toujours à l'affût des ragots; (E) to have itching ears

puce à l'oreille l'homme réveille (1557) (cf. mettre la puce à l'oreille de qqn)

qui tend l'oreille, qu'il se la gratte! en écoutant aux portes on n'entend pas dire que du bien de soi; (E) eavesdroppers hear not only good of themselves rebattre les oreilles à qqn (1640) (cf. casser les oreilles à qqn)

rebattre les oreilles de qqch (17) répéter toujours la même chose à qqn; $(\mathrm{E})$ to be always ramming it down s.o.'s throat

rompre les oreilles à qqn (1640)

(cf. casser les oreilles à qqn) 
rougir jusqu'aux oreilles

(cf. rougir jusqu'à la racine des cheveux)

sa bouche dit à ses oreilles que son menton touche son nez (1842)

(cf. bouche)

savonner les oreilles à qqn (17)

1. cf. battre les joues à qqn

2. cf. prendre qqn aux cheveux

se faire savonner les oreilles (17)

(cf. avoir sur les doigts)

se faire tirer l'oreille (1562)

se faire prier; (E) to need a lot of coaxing se gratter l'oreille (1690)

1. avoir peine à se rappeler; (E) to have

trouble in remembering

2. être embarrassé; (E) to be embarrassed secouer les oreilles (1690)

1. ne pas se soucier de ce qui est dit; (E) not

to care about what is said

2. signifier que qqch est mauvais; (E) to

indicate that sthg is no good

souffler aux oreilles de qqn (1640)

1. cf. tâter le biceps à qqn

2. inciter qqn à faire qqch; (E) to prompt

s.o. to do sthg

souffler qqch à l'oreille de qqn

(cf. confier qqch dans le tuyau de l'oreille)

sourire jusqu'aux oreilles

large sourire; (E) smile from ear to ear

tendre l'oreille

(cf. dresser l'oreille)

tirer les oreilles à qqn

châtier qqn pour quelque petit méfait; (E) to pull s.o.'s ears

venir aux oreilles de qqn

venir à la connaissance de qqn; (E) to come to s.o.'s ears

venir ravauder aux oreilles de qqn (1690)

(cf. casser les oreilles de qqn)

ventre affamé n'a point d'oreilles (1656)

celui qui a faim n'écoute rien ni personne;

(E) the belly has no ears, the belly hates a

long sermon, hungry bellies have no ears

vin à deux oreilles (1640)

très mauvais vin (on le montre en secouant deux fois la tête, c'est-à-dire les oreilles);

(E) poor quality wine

ORTEIL

avoir les orteils en éventail (20)

(cf. avoir les DOIGTS de pied en bouquets de violettes)

chlinguer de l'orteil (19)

puer des pieds; (E) to have smelly feet saigner une femme entre les deux gros orteils (16) (cf. mettre chair vive en chair vive)

se faire ventouser entre les deux gros orteils

(1640)

(cf. faire commerce de son corps; manger de

la chair crue)

se signer des orteils (1867)

se pendre ou être pendu; (E) to bless the

world with one's heels, to wear a hempen

necktie

OS

avoir l'os (1931)

(cf. dresser l'oreille 2)

briser/ casser les os à qqn

(cf. rompre BRAS et jambes à qqn)

cavaler/ courir sur l'os à qqn (1916)

(cf. faire la barbe à qqn 6)

en chair et en os (1640)

(cf. chair)

être de chair et d'os

(cf. chair)

être encore en chair et en os (1690)

(cf. chair)

être gelé jusqu'à la moelle des os/ jusqu'aux os (cf. moelle)

être mouillé/ percé/ trempé jusqu'aux os (1608)

(cf. trempé jusqu'à la moelle)

faire juter l'os à moelle (1907)

(cf. moelle)

faire une corbeille d'os de qqn

(cf. rompre BRAS et jambes à qqn)

il ne fera jamais/ pas de vieux os (1640)

il n'a pas une bonne santé; (E) he won't make old bones

il n'y a pas point de belle chair près des os (cf. chair)

il y a un os! (1914)

(cf. il y a un cheveu!)

ils sont de chair et d'os comme nous (1640)

(cf. chair)

j'ai l'os du foie qui me fait mal (20)

(cf. foie)

l'avoir dans l'os (1948)

(cf. l'avoir dans le cul)

la peau lui tient aux os (1640)

(cf. la peau lui tient aux CÔTES)

n'avoir pas de moelle dans les os

(cf. avoir des bras de saindoux)

n'avoir que la peau et les os (1531)/ la peau sur

les os (1668)

(cf. la peau lui tient aux CÔTES)

n'être qu'un paquet d'os (16)

(cf. ci-dessus)

ne pas faire de vieux os

1. mourir jeune (18); (E) not to make old

bones 
2. ne pas rester longtemps en un même lieu;

(E) not to stay long in the same place numérote tes os! (1867)

menace de correction; (E) I'll break every bone in your body!, I'll spit in your eye and choke you!, I'll push your face in!

1. cf. œil (1895)

2. cf. cheveu (1914)

3. pénis en érection; (E) erect penis os à moelle (1907)

(cf. moelle)

paquet d'os

(cf. sac d'os)

pisser des os (17)

(cf. faire un pet à vingt ongles)

pisser son os (17)

avorter; (E) to have an abortion

rogner l'os (1948)

(cf. se laver les dents)

rompre les os à qqn (17)

(cf. rompre BRAS et jambes à qqn)

ronger qqn jusqu'aux os (1640)

(cf. manger la laine sur le dos de qqn)

sac d'os (1914)

personne très maigre; (E) bag of bones, bare-

bones, rattlebones (US), thin-gut, living

skeleton, skin-a-guts, skin and grief

sauver ses os

sauver sa vie, sortir indemne; (E) to save one's ass (US), to save one's neck/ skin, to come out of it with a whole skin

se casser les os

(cf. se casser les dents)

se polir l'os (1948)

(cf. se faire sauter la cervelle 2)

taper sur l'os (1916)

(cf. faire la barbe à qqn 6)

tirer la moelle des os à qqn

(cf. manger la laine sur le dos à qqn)

y laisser ses os

y perdre la vie; (E) to leave one's bones

somewhere

PAUPIÈRE

fermer la paupière/ les paupières

1. cf. plier les cils (1601)

2. cf. raidir le jarret (1660)

ouvrir la paupière

s'éveiller; (E) to wake up

paupières en capote de cabriolet (1851)/ de

fiacre (20)

paupières très plissées; (E) wrinkled eyelids

s'en battre/ fustiger la paupière (1872)

(cf. se torcher le cul de)
PEAU

à fleur de peau (17) peu profond, superficiel; (E) skin-deep

à même la peau sur la peau; (E) next to one's skin

attraper qqn par la peau du cou (cf. cou)

avoir la peau de qqn (1676)

(cf. casser le cou à qqn 1)

avoir la peau dure (19)

être résistant; (E) to have a thick skin

avoir la peau trop courte

1. cf. avoir les bras cassés (1977)

2. péter (1867); (E) to cut a/ one's finger, to

blow one's guts out, to drop one's guts

avoir qqn dans la peau (1896)

(cf. avoir un cheveu pour qqn)

avoir une perruque en peau de fesses (1977)

(cf. avoir la tête qui dépasse des CHEVEUX)

bouffer à s'en faire crever/ péter la peau du

ventre

goinfrer; (E) to blow one's hide out

coller sa peau (1756)

(cf. se mettre la corde au cou)

coûter la peau du cul/ des fesses (20)

(cf. cul)

craindre pour sa peau

avoir peur pour sa vie; (E) to fear for one's

skin

crever dans sa peau

1. avoir une mine florissante; (E) to be

bursting with health

2. éprouver colère ou dépit; $(\mathrm{E})$ to be

bursting with anger or spite

3. être à l'étroit dans ses vêtements; (E) to

be bursting out of one's clothes

crever la peau à qqn (19)

(cf. casser le cou à qqn 1)

défendre sa peau

lutter pour sa (sur)vie; (E) to fight for one's skin

en peau (1875)

très décolletée; (E) low-necked

entrer dans la peau de qqn

s'identifier à qqn; (E) to identify oneself

with s.o.

être bien dans sa peau (1914)

se sentir bien aise; (E) to feel comfortable and happy

être dans la peau de qqn (1640)

être à la place de qqn; (E) to be in s.o.'s place

être gras à pleine peau

être extrêmement gros; (E) to be a pot-belly 
être mal dans sa peau (20)

n'être pas heureux; (E) to feel uncomfortable, unhappy

faire bon marché de sa peau (1690)

(cf. faire bon marché de son corps)

faire la peau (1946)

(cf. faire commerce de son corps)

faire la peau à qqn (1850)

(cf. casser le cou à qqn 1)

faire peau neuve

1. renouveler sa garde-robe; (E) to renew one's wardrobe

2. changer de caractère, de conduite; (E) to turn over a new leaf

foutre douze balles dans la peau à qqn (19) fusiller qqn; (E) to execute s.o. by shooting

il faut la couvrir de la peau d'un chrétien (1640) il faut lui faire l'amour pour la guérir; (E) she should have intercourse to get well

il mourra dans sa peau, il ne changera jamais de peau (17)

il est incorrigible; (E) he cannot change his skin

je ne voudrais pas être dans sa peau (1640)

je n'aimerais pas être à sa place; (E) I

wouldn't like to be in his shoes

la peau! (1883)

(cf. mon cul!)

la peau d'un chrétien est bonne pour échauffer

l'estomac d'une fille (1640)

(cf. estomac)

la peau est plus proche que la chemise (1842) les intérêts personnels priment ceux d'autrui; (E) near is the shirt, but nearer is the skin

la peau lui démange (1690)

il cherche la punition; (E) he's itching for trouble

la peau lui tient aux côtes/ aux os (17) (cf. côte)

lever des aiguillettes de la peau de qqn (1640) (cf. rompre BRAS et jambes à qqn)

lever la peau à qqn (1640) (cf. ci-dessus)

manger la peau sur le dos à qqn (cf. dos)

n'avoir que la peau et les os (1531)/ sur les os (1668)

(cf. la peau lui tient aux CÔTES)

ne pas changer de peau (1585) être incorrigible; (E) to refuse to change

ne pas donner cher de la peau de qqn ne croire guère aux chances de qqn; (E) not to give much for s.o.'s chances ne pas savoir que faire de sa peau

traînailler sans but; (E) to arsel ass (US)

about, to drag-ass around (US), to fart-arse/ piss-arse about/ around

ne pas tenir dans sa peau (1640)

1. se gonfler de fierté; (E) to be stuck-up

2. exploser de joie; (E) to leap with joy

3. bouillir d'impatience; (E) to jump out of one's skin

on n'aura point envie à sa peau (1690)

(cf. sa BOUCHE dit à ses oreilles que son menton touche son nez)

реau (1845)

prostituée; (E) ass-peddler (US), split-arse mechanic, belly-piece, bloodsucker (US), buttock/ flesh peddler (US), foreskin-hunter, (dirty) leg, merry-legs, glue neck (US), whisker

peau de balle! (1877), peau de balle et balai de crin! (1881)

rien du tout!; (E) nothing (doing)!

peau de bite (1878)/ de nœud (1881)/ de zébi

(1870)!

(cf. ci-dessus)

peau de fesse (20)

(cf. fesse)

Peau-Rouge

1. Indien d'Amérique (1842); (E) Redskin

2. voyou (1883); (E) hooligan

péter dans sa peau

être bouffi d'orgueil; (E) to be too big for one's boots

porter à la peau de qqn (1867)

exciter la sensualité de qqn; (E) to arouse s.o.'s sensuality

prendre qqn par la peau du dos

(cf. dos)

qui lui piquerait la peau, il n'en sortirait que du vent (1640)

1. il est d'une extrême vanité; (E) he is eaten up with pride

2. il est d'une grande ignorance; (E) he is a complete ignoramus

quitter sa peau (18)

(cf. faire peau neuve)

risquer sa peau (1656)

prendre un gros risque, risquer sa vie; (E) to put one's ass on the line (US), to stick out one's chin (US), to put one's neck on the line, to stick one's neck/ nose out

s'appliquer la peau d'un garçon (1864)

(cf. manger de la chair crue)

sauver sa peau (1320)

(cf. sauver ses os) 
se faire la peau (1936)

(cf. se brûler la cervelle)

se faire trouer la peau (1885)

être tué (par arme à feu); (E) to get shot

se jeter sur la peau de qqn (1640)

(cf. rompre BRAS et jambes à qqn)

se lever la peau (20)

(cf. se casser le cul)

se mettre dans la peau de qqn

(cf. entrer dans la peau de qqn)

se sentir bien dans sa peau (1914)

(cf. être bien dans sa peau)

sous la peau d'un homme plusieurs bêtes ont ombre (1557)

tout homme a des pensées inavouables;

(E) every man fosters shameful thoughts tanner la peau à qqn

(cf. rompre BRAS et jambes à qqn)

traîner sa peau

(cf. ne pas savoir que faire de sa peau)

travailler pour la peau

se donner du mal pour rien; (E) to work for beans

trouer la peau à qqn (1885)

(cf. casser le cou à qqn 1)

vendre cher sa peau (1575)

se défendre avec acharnement; (E) to sell one's skin dearly

vieille peau

1. vieille prostituée (1845); (E) old prostitute

2. vieille femme (1883); (E) old woman y laisser sa peau (15)

1. cf. y laisser ses os

2. succomber à la tâche; (E) to die in harness

\section{PERINÉE}

soutenir le périnée à qqn

(cf. prêter son bras)

\section{PÉRITOINE}

s'en faire éclater le péritoine (1867)

1. cf. s'arroser les amygdales

2. cf. se caler les amygdales

\section{PHALANGE}

phalanges (19)

les mains; (E) the hands

serrer la phalange à qqn (1881)

donner la main à qqn; (E) to give s.o. one's fist, to press the flesh, to shake hands, to give s.o. skin (US)

PHALANGETTE

phalangettes (19)

les doigts; (E) the fingers

\section{PIED}

à chaque pied son soulier (Montaigne, 1588)

(cf. trouver chaussure à son pied) aller à beaux pieds sans lance (17)

(cf. aller à pied)

aller à pied (11)

marcher; (E) to ankle it (US), to foot it, to

travel by Mr. Foot's horse, to leg it, to take

the shin-stage

aller à pied comme un Basque (1690)

marcher vite (et longtemps); (E) to hot-foot

it

aller du pied (1640)

(cf. aller à pied)

aller du pied comme un chat maigre (1640)

(cf. avoir de bonnes jambes)

aller où le roi va à pied (1640)

aller aux toilettes; (E) to go where the queen goes on foot, to powder one's face (f), to wash one's hands, to powder one's nose (f)

aller se laver les pieds (19)

être déporté au bagne; (E) to be sent to hard labour

assez écorche qui le pied tient (13)

qui soutient un complice se rend complice;

(E) helping an accomplice makes you an accomplice

au pied levé (1549)

à l'improviste, sur-le-champ; (E) off-hand, out of hand

avoir bon pied bon œil (1527)

(cf. œil)

avoir des fourmis aux pieds (1894)

avoir des fourmillements; (E) to have pins

and needles in one's foot

avoir des fourmis sous les pieds

ne pas tenir en place; (E) to have itchy feet

avoir froid aux pieds (1640)

être jaloux; (E) to be jealous

avoir la tête qui sent des pieds (20)

être de très petite taille; $(E)$ to be very short of stature

avoir le pied à l'étrier

1. être sur le point de partir (1690); (E) to

be on the point of leaving

2. être bien parti pour réussir (19); (E) to be well on the way to success

avoir le pied marin (1616)

n'être pas incommodé par les mouvements de la mer; (E) to have found one's sea-legs avoir les pieds chauds

(cf. les mains sous le menton, les COUDES sur la table)

avoir les pieds dans le dos/ les reins

(cf. dos)

avoir les pieds en bouquets de violettes (1957)

(cf. avoir les DOIGTS de pied en bouquets de violettes) 
avoir les pieds en cosses de melon (20) (cf. avoir les bras cassés)

avoir les pieds nickelés

1. cf. tirer au cul (1898)

2. cf. avoir du cul (1977)

avoir les pieds poudreux (1640)

1. cf. faire jambe de bois

2. être insolvable; (E) to be insolvent

avoir les pieds retournés (20)

(cf. avoir les bras cassés)

avoir les pieds sous la table, les coudes sur la table (1690)

(cf. coude)

avoir les (deux) pieds sur terre

(cf. avoir la tête sur les ÉPAULES)

avoir mangé ses pieds (1867)

(cf. avoir les DENTS qui prennent racine

dans le trou du cul)

avoir pied (1671)

sentir le sol au fond de l'eau; (E) to feel the ground under one's feet

avoir pied sur qqn (1640)

avoir autorité sur qqn; (E) to have authority over s.o.

avoir toujours le/ un pied en l'air (1690) être toujours en mouvement; (E) to be always on the go

avoir un pied dans deux chaussures avoir le choix entre deux choses également avantageuses; (E) to have two strings to one's bow

avoir un pied dans la fosse (1660)/ dans la tombe (1845)

1. cf. avoir la mort entre les dents

2. être très âgé/ très malade; $(\mathrm{E})$ to have one foot in the grave

avoir un pied quelque part

1. être admis en un lieu; (E) to have gained a footing somewhere

2. avoir un intérêt dans qqch; (E) to have a finger in the pie/ a foot in the dish 3. avoir de l'influence quelque part; (E) to have influence somewhere

bain de pied (1872) beaucoup, une quantité de; (E) lots of

baiser la poussière des pieds de qqn (cf. embrasser les genoux de qqn)

baiser les pieds de qqn (cf. ci-dessus)

bénir des pieds

1. cf. se signer des orteils (18)

2. cf. avoir les DOIGTS de pied en bouquets de violettes (1864)

ça lui fera les pieds!

cela lui servira de leçon!; (E) that's one in the eye for him!

ça vaut mieux qu'un coup de pied au cul!

(cf. cul)

casse-pieds (1890)

(cf. barbe 2)

casser les pieds à qqn (1890)

(cf. faire la barbe à qqn 6)

ce qu'il a dans la tête, il ne l'a pas aux pieds

(cf. quand il a qqch à la tête, il ne l'a pas au CUL)

cheminer autrement que des pieds (17)

(cf. mettre chair vive en chair vive)

chercher à pied et à cheval (1640)

chercher avec grand soin; (E) to spare no

troubles to find sthg

coup de pied (1867)

emprunt aux garanties douteuses;

(E) dubiously secured loan

coup de pied de Vénus (1866)

maladie vénérienne; (E) venereal disease

couper l'herbe sous le pied de qqn (16)

faire obstacle à, supplanter qqn; (E) to cut

the grass/ ground from under s.o.'s feet

d'arrache-pied (1515)

opiniâtrement, sans discontinuer; (E) steadily, without interruption

de la tête aux pieds

sur tout le corps; (E) from head to foot, from

top to toe

de pied coi (16)

courageusement, sans reculer; (E) bravely,

resolutely

de pied en cap (16)

(cf. de la tête aux PIEDS)

de pied ferme (1587)

(cf. de pied coi)

demeurer sur ses pieds (1640)

subsister quelles que soient les circonstances;

(E) to keep body and soul together

détacher un coup de pied à qqn (1867)

frapper qqn du pied; (E) to kick s.o.

donner du pied (1640)

mépriser, rejeter; (E) to disregard, to turn down

donner un coup de pied (1808)

(cf. aller à pied comme un Basque)

donner un coup de pied dans une fourmilière provoquer une agitation inquiète; (E) to cause an anxious agitation

être à pied sans lance (1690)

être mal dans ses affaires; (E) to be doing badly

être à nouveau sur pied (1685)

être rétabli; (E) to be on one's feet/ legs again 
être à quatre pieds (16)

(cf. être en cloque jusqu'aux genoux)

être bête comme ses pieds (1867)

(cf. avoir le cerveau vide)

être/ rester les deux pieds dans le même sabot/

soulier (19)

être embarrassé, incapable d'initiative; (E) to

be at loss, to lack initiative

être mis à pied

1. être déshonoré, ruiné (17); (E) to be

disgraced, ruined

2. être suspendu dans ses fonctions (1898);

(E) to be dismissed

être pieds et poings liés

être réduit à l'impuissance; (E) to be bound hand and foot

être sur le pied gauche (17)

être dans une position embarrassée, être mal

à l'aise; (E) to feel awkward, uncomfortable

être sur pied (1685)

1. cf. être à nouveau sur pied

2. être levé; (E) to be up (and about)

faire des pieds et des mains (20)

(cf. main)

faire (des) pieds neufs (17)

(cf. faire un pet à vingt ongles)

faire du pied à qqn (10)

(cf. faire du genou à qqn)

faire haut le pied (1771)

(cf. prendre ses jambes à son $\mathrm{COU}$ )

faire le pied derrière (1690)

faire la révérence; (E) to make a bow

faire le pied de grue (17)

attendre longuement; (E) to cool one's heels

faire les pieds à qqn (20)

1. endurcir qqn; (E) to inure s.o.

2. servir de leçon à qqn; (E) to teach s.o. a lesson

faire qqch comme un pied (1872)

faire qqch très mal; $(E)$ to bungle sthg

faire qqch sur pied (1955)

(cf. les DOIGTS dans le nez)

faire un appel du pied (20)

faire une invite discrète; (E) to make discreet advances

flanquer des coups de pied au cul de qqn

(cf. botter le cul à qqn)

fouler qqch aux pieds (14)

traiter qqch avec mépris; (E) to trample/

tread sthg under one's foot

fouler qqn aux pieds (14)

(cf. rompre BRAS et jambes à qqn)

foutre son pied au cul de qqn

(cf. botter le cul à qqn) foutre un coup de pied à qqn (1867)

(cf. tirer une dent à qqn)

gagner au pied (17)

(cf. prendre ses jambes à son COU)

gratter les pieds à qqn (1640)

(cf. baiser le cul à qqn)

il a des cors aux pieds (1640)

il est très lent; (E) he is very slow

il a les pieds chauds (il veut jaser) (1640)

il a ses aises, il veut bavarder; (E) he is cosy, he feels like a chat

il a trouvé chaussure/ forme à son pied (1640) il a trouvé à qui parler; il a trouvé qui épouser; (E) he has come up against his match

il croit tenir Dieu par les pieds (17)

(cf. ne pas tenir dans sa peau 2)

il est aisé d'aller à pied quand on tient son

cheval par la bride (13)

la privation est facile quand on a les moyens d'y mettre fin; (E) privation is easy when one has the means to stop it

il fait rage de/ avec ses pieds tortus (1640)

1. il fait de son mieux; (E) he is doing his utmost

2. il ne fait rien qui vaille; (E) he is a goodfor-nothing

il faut plutôt prendre garde à ses mains qu'à ses pieds (1640)

(cf. main)

il ne faut (jamais) trembler qu'on ne voie sa tête à ses pieds (1616)

il ne faut pas avoir peur sans raison; (E) one should not fear without reason

il ne saurait tomber que debout, il retombe

toujours sur ses pieds (1690)

il a beaucoup d'appuis; (E) he has many friends at court

il semble qu'il ait les pieds dans le feu (1640) (cf. ne pas tenir dans sa peau 3)

il vaut mieux glisser du pied que de la langue (1842)

(cf. langue)

il y a des coups de pied au cul qui se perdent (20)

(cf. cul)

j'ai des fourmis dans le pied mon pied est engourdi; (E) my foot has gone to sleep

je ne voudrais pas en détourner le pied (1640) je ne me dérangerais pas pour cela; (E) I wouldn't go out of my way for it je sais de quel pied il cloche (1640) je connais sa façon de faire; (E) I know his ways 
jouer aux pieds nickelés (20) faire le petit voyou; (E) to act the hooligan jouer comme un pied (1872) jouer très mal; $(\mathrm{E})$ to be an atrocious player jouer de l'épée à deux pieds (1640) (cf. prendre ses jambes à son COU)

la sauter à pieds joints (20)

(cf. dîner par cœur)

lâcher (le) pied

1. cf. baisser les bras (1690)

2. céder, reculer (1656); (E) to back down

les petits pieds lui font mal (1640)

(cf. elle a bu la bouteille, le bouchon lui est demeuré dans le corps)

les pieds lui démangent

1. cf. avoir des fourmis sous les pieds (1690)

2. il a envie de partir; (E) he is itching to go lever le pied

1. cf. prendre ses jambes à son $\mathrm{COU} 1$

(1799)

2. s'enfuir avec l'argent confié (19); (E) to

abscond with entrusted money

3. ralentir (vitesse, activités) (20); (E) to

slow down (speed, work)

lutter des pieds et des mains (cf. main)

marcher à quatre pieds (1896)

(cf. être en cloque jusqu'aux genoux)

marcher de bon pied (1640)

procéder comme il faut, s'y prendre bien;

(E) to make a good fist at

marcher sur le(s) pied(s) de qqn (18)

offenser qqn, traiter qqn sans égards; (E) to step/ tread on s.o.'s toes

meilleurs nus pieds que nuls pieds (1557)

mieux vaut être pauvre qu'infirme; (E) one foot is better than two crutches

mettre à qqn le pied à l'étrier (1640)

favoriser les débuts de qqn; (E) to help s.o. make a start

mettre la tête où l'on a les pieds (1640)

(cf. mettre le cul en haut)

mettre le pied au plancher/ sur la planche (20) accélérer; (E) to have one's foot on the floor, to put one's foot down

mettre le pied dans la vigne du Seigneur (17) (cf. prendre sa barbe)

mettre le pied/ les pieds en quelque lieu (1640) entrer quelque part; (E) to set foot in some place

mettre les pieds dans le plat

1. cf. se fourrer le doigt dans l'œil jusqu'au COUDE (1903)

2. ne prendre aucun ménagement (1808);

(E) to put one's foot in it mettre qqn à pied (1823)

démettre qqn, renvoyer qqn; (E) to dismiss s.o.

mettre qqn sous les/ ses pieds (1640)

1. cf. tenir le pied sur la GORGE à qqn

2. cf. mettre qqn au trou de son cul

mettre sur pied (17)

1. lever des troupes; (E) to raise troops

2. établir, organiser; (E) to get sthg on its feet

n'aimer pas qu'on vous marche sur les pieds (1867)

(cf. prendre le mors aux dents 3)

n'avoir pas les deux pieds dans le même sabot (20)

être vif, actif, débrouillard; (E) to be a live wire, a resourceful man

ne pas/ plus savoir sur quel pied danser (1611) être dans l'indécision la plus complète;

(E) not to know which way to turn

ne pas se donner de coups de pied

(cf. se donner des coups de pied dans les CHEVILLES)

ne pas se laisser marcher sur les pieds (1791)

regimber, protester; (E) to kick

ne pas se moucher du pied (1611)

(cf. ne pas se moucher du coude)

ne pas se trouver sous le pied

n'être pas facile à se procurer; (E) not easy to come by

ne (plus) pouvoir mettre un pied devant l'autre (18)

1. cf. avoir les bras rompus

2. cf. avoir sa barbe

ne plus mettre les pieds chez qqn cesser de fréquenter qqn; (E) never to

darken s.o.'s door again

ne remuer ni pied ni patte (1643)

1. cf. être guéri du mal de dents

2. être absolument immobile; (E) to stand stock-still

n'y marcher pas de bon pied (1640)

(cf. à cour failli)

on lui a mis la tête à ses pieds (1640)

(cf. faire la barbe à qqn 5)

partir du bon pied (20)

bien commencer; (E) to put one's best foot foremost/ forward

partir du pied droit (1867)

(cf. ci-dessus)

partir du pied gauche prendre un mauvais départ; (E) to start off on the wrong foot

partir les pieds devant (1460)

(cf. être guéri du mal de dents; raidir le 
jarret 2)

perdre les pieds pour qqn (17)

(cf. avoir un cheveu pour qqn)

perdre pied (17)

1. ne plus sentir le sol; (E) to lose one's

foothold

2. ne plus savoir comment réagir; (E) to be carried off one's leg

pied (1872)

(cf. cervelle à double rebras)

pied à pied (1580)

peu à peu, graduellement; (E) foot by foot

pied bleu (19)

conscrit; (E) recruit

pied de plomb (1640)

lambin, traînard; (E) slowcoach

pied gris (17)

(cf. cul-terreux)

pied noir (20)

Français né en Algérie; (E) Algerian-born

French citizen

pied plat (1560)

(cf. cul-terreux)

pieds à dormir debout (1867)

grands pieds; (E) big feet

prendre pied (14)

1. s'introduire quelque part; (E) to get one's

foot in

2. s'implanter; (E) to gain/ get à foothold/ footing

prendre pied sur les actions de qqn (1640)

se prévaloir des actes de qqn; (E) to take advantage of s.o.'s deeds

prendre pied sur qqn (1640)

(cf. avoir pied sur qqn)

prendre qqn au pied levé (1690)

prendre qqn à l'improviste; (E) to catch s.o. unprepared

prendre un bain de pieds (1872)

(cf. aller se laver les pieds)

qui veut un cheval sans défaut doit aller à pied (13)

la perfection n'est pas de ce monde;

(E) perfection does not exist

recevoir un coup de pied de Vénus (1866) contracter une maladie vénérienne; (E) to burn one's finger, to break one's shins against Covent Garden rails, to stub one's toe

remettre à qqn le pied à l'étrier (1640)

aider qqn à redémarrer; (E) to help s.o. to his feet

remettre qqch sur pied

rétablir qqch, relancer qqch; (E) to get sthg on its feet again, to set sthg on its legs again remettre qqn sur pied

1. cf. remettre à qqn le pied à l'étrier (1669)

2. rétablir (la santé de) qqn; (E) to get s.o. back on his feet, to set s.o. on his feet/ legs again

retomber (toujours) sur ses pieds (1685)

se tirer de toutes situations; (E) to fall always on one's feet

s'emmêler les pieds

1. trébucher; (E) to stumble

2. s'embrouiller; (E) to get confused

s'en aller les pieds devant (15)

(cf. être guéri du mal de dents; raidir le jarret 2)

s'être levé du pied gauche (19)

être de mauvaise humeur; (E) to have one's

back up, to have a liver, to be in a bad skin

s'y prendre comme un pied (20)

(cf. rompre l'andouille au genou 2)

sa tête donne bien du mal à ses pieds (1690)

(cf. on connaît à ses YEUX que sa tête n'est pas cuite)

sauter à deux pieds sur le ventre de qqn (1640)

(cf. rompre BRAS et jambes à qqn)

savoir où l'on met les pieds

ne prendre aucun risque; (E) to be sure of one's ground

se donner des coups de pied au cul (cf. cul)

se jeter aux pieds de qqn

(cf. embrasser les genoux de qqn)

se lever du pied gauche (20)/ du mauvais pied commencer la journée de mauvaise humeur; (E) to get out of bed on the wrong side

se prendre les pieds dans le tapis (cf. s'emmêler les pieds)

se tirer des pieds (1867) (cf. prendre ses jambes à son COU)

se tirer une épine du pied (17)

surmonter quelque difficulté; (E) to get out of some predicament

se trouver toujours sur ses pieds(1690)

(cf. demeurer sur ses pieds)

sécher sur le pied (17)/ sur pied (18)

1. cf. en avoir plein le cul 2

2. cf. faire le pied de grue

3. se consumer de désir; (E) to pine away with desire

sentir le pied de ménage (1640)/ de messager (1690)

sentir mauvais; (E) to stink

si vous lui donnez un pied, il vous prendra la jambe

(cf. si on lui en donne un pouce, il en prendra grand comme le BRAS) 
sortir les pieds en avant (15)

(cf. être guéri du mal de dents; raidir le jarret 2)

sur la pointe des pieds (1669)

1. silencieusement; (E) on the points of one's toes, on tip-toe

2. prudemment; (E) idem

tenir le pied sur la gorge à qqn (16)

(cf. gorge)

tenir les pieds à qqn (1640)

(cf. donner le coup d'épaule à qqn)

tenir pied (17)

persévérer, résister; (E) to keep one's chin up, to hang on/ hold on by one's eyebrows/ eyelashes, to keep one's feet

tenir pied à boule (1842)

(cf. ci-dessus)

tirer une épine du pied à qqn (17)

délivrer qqn d'un grand souci; (E) to take a load off s.o.'s heart

tomber sur ses pieds (1640)

(cf. retomber toujours sur ses pieds)

traîner les pieds (20)

1. faire qqch à contrecœur; (E) to drag one's heels

2. avancer lentement; (E) idem.

trouver chaussure à son pied (1606)

1. trouver ce qui convient; (E) to find the proper thing

2. trouver à se marier; (E) there's a shoe to

fit every foot (US)

un pied chaussé, l'autre nu (1690)

en toute hâte; (E) head and shoulders, head over heels

va te laver les pieds! (20)

(cf. tournez-moi le dos!)

vous m'avez tiré une belle/ rude épine hors du pied! (17)

vous m'avez tiré d'embarras; (E) that's a relief!

POIGNET

à la force du poignet (20)

avec énergie et volonté; (E) by sheer strength of arm

avoir les poignets coupés (1907)

refuser un service; (E) to refuse to do a service

épouser la veuve poignet (1948)

(cf. se faire sauter la cervelle 2)

huile de poignet (1867)

(cf. huile de bras)

jouer du poignet (1640)

(cf. se faire sauter la cervelle 2)

la veuve Poignet/ poignet (1830) masturbation; (E) Mary Fist, fist-fuck, Mrs.
Hand, hand-jive (US), hand-job, one-legged race

ne pas avoir les poignets coupés (1907)

(cf. avoir le CEEUR sur la main 1)

ne pas se fouler le poignet (1842)

éviter l'effort, ne pas se fatiguer; (E) not to break/ strain one's back, not to lift a finger, not to bust a gut

se casser le(s) poignet(s) sur qqch

(cf. avoir les doigts crochus 2)

POIL

à poil

1. courageux (1793); (E) lion-hearted

2. entièrement nu (1858); (E) bare-assed

(US), belly-naked, laid to the naked bone, all

face, naked as one's nail, stripped to the skin

à un poil près (1907)

(cf. à un cheveu près)

au paresseux le poil lui pousse dans la main (1842)

(cf. avoir les bras cassés)

au (petit) poil (1907)

1. cf. au poil de CUL près

2. excellent, parfait; (E) first-rate, super

au poil de cul près (1907)

(cf. cul)

au quart de poil (1907)

(cf. au poil de CUL près)

avoir des poils au bout des doigts (1866)

(cf. avoir les bras cassés)

avoir du poil (1867)

(cf. avoir du CCEUR au ventre)

avoir du poil au cœur (1836)/ au cul (1867) /

aux dents (1894)/ aux yeux (1842)

(cf. cœur)

avoir eu le poil de qqn (1690)

avoir vaincu qqn; (E) to have defeated s.o. avoir le poil de (faire qqch) (1867)

(cf. avoir le front de)

avoir qqn sur le poil (1915)

(cf. avoir qqn sur les bras)

avoir un poil dans la main (1808)

(cf. avoir les bras cassés)

carder le poil à qqn

(cf. rompre BRAS et jambes à qqn)

caresser qqu dans le sens du poil

1. cf. tâter le biceps à qqn

2. amadouer, calmer qqn; (E) to smooth

s.o.'s feathers

changer de poil (16)

(cf. faire peau neuve 2)

coucher le poil à qqn

(cf. tâter le biceps à qqn)

être à poil (1858)

(cf. à poil 2) 
être bas de poil (1640)

avoir peu d'argent; (E) to be short of money

être de bon poil (1833)

être de bonne humeur; (E) to be in good/ strong heart

être de mauvais poil (1833)

(cf. s'être levé du pied gauche)

faire le poil à qqn (1834)

1. cf. faire une barbe à qqn

2. cf. toucher les épaules à qqn

flanquer un poil à qqn (1849)

1. cf. prendre qqn aux cheveux

2. cf. rompre BRAS et jambes à qqn

gars à poil (1896)

(cf. va-du-gland)

il s'en est fallu d'un poil (1926)

à un rien près, cela se produisait; (E) it hung

by a hair, it was a hairbreadth escape, it was

within a hair's breadth of

il se laisserait arracher la barbe poil à poil (1690) (cf. barbe)

il y a laissé du poil (1583)

il a dépensé / perdu beaucoup d'argent;

(E) he spent/ lost a lot of money

le poil lui reluit (1640)

(cf. avoir le CUL sur le visage)

n'avoir plus un poil de sec (1878)

1. cf. avoir chaud au cul 1

2. cf. être mouillé jusqu'aux os

n'avoir plus un poil sur le caillou (1866)

(cf. avoir la tête qui dépasse des CHEVEUX)

poil de carotte (1894)

personne aux cheveux roux; (E) redhead

prendre du poil de la bête (1640)

(cf. mettre chair vive en chair vive)

reprendre du poil (18)

1. cf. reprendre cœur

2. cf. être à nouveau sur pied

se laisser arracher la barbe poil à poil (1690)

(cf. barbe)

se mettre à poil (1858)

se dévêtir complètement; (E) to air one's

pores, to cast one's skin, to strip to the skin tirer le poil à qqn (1872)

(cf. rompre BRAS et jambes à qqn)

tomber sur le poil à qqn (1872)

(cf. tomber sur le dos de qqn)

tout me vient à contre-poil (1640)

tout m'est contraire; (E) fate is against me

un poil fait ombre (1611)

il n'y a pas d'ennemi insignifiant; (E) there

is no negligible enemy

vous devenez bête, le poil vous vient sous les aisselles (1640)

(cf. aisselle)
POING

ça lui va comme un coup de poing dans l'œil cela ne lui va pas du tout (chapeau, vêtement, etc.); (E) it doesn't suit her/ him at all

coup de poing

coup donné avec la main fermée; (E) slice of

knuckle-pie, knuckle-sandwich

donner un coup de poing sur la table

(cf. donner un coup de gueule 2)

dormir à poings fermés (1834)

(cf. dormir sur ses deux oreilles)

en venir aux poings (1566)

(cf. en venir aux mains)

être pieds et poings liés

(cf. pied)

faire le coup de poing (1666)

se battre (avec les poings); (E) to use one's fists

jouer des poings (19)

(cf. ci-dessus)

manger sur le poing de qqn

(cf. manger dans la main de qqn 2)

mettre le(s) poing(s) sur la/ les hanche(s)

(cf. hanche)

montrer le poing (1680)

(cf. menacer qqn du doigt)

se mordre / ronger les poings (1769)

(cf. se ronger les ongles)

tendre le poing (1680)

(cf. menacer qqn du doigt)

POITRINE

casse-poitrine (1864)

(cf. la veuve poignet)

ragoût de poitrine (1764)

seins féminins; (E) fore-buttocks, chest

decorations, (brown) eyes (US), hands (US), hand-warmers, lungs (US), lung warts (US), tonsils (US)

s'en aller de la poitrine (17)

mourir de tuberculose; (E) to die of consumption

POUCE

avoir le pouce rond (1867)

(cf. avoir de l'esprit au bout des doigts)

avoir les pouces à la ceinture (1611)

(cf. demeurer les bras croisés 1)

avoir les pouces gelés (1912)

(cf. être à cul 1)

avoir mal au pouce (1912)

(cf. ci-dessus)

c'est si bon qu'on en mangerait ses pouces

(1690)

(cf. on s'en lècherait les cinq DOIGTS et le pouce) 
coup de pouce (1847)

(cf. coup de main 2)

donner le coup de pouce (1872)

tricher sur le poids en donnant de l'élan à la

balance; (E) to weigh the thumb in

donner le coup de pouce à qqch

1. cf. mettre la dernière main à qqch (1874)

2. faire avancer une affaire (1852); (E) to give sthg the push

donner le coup de pouce à qqn (1783)

(cf. serrer le cou à qqn)

donner un coup de pouce à qqn (1852)

(cf. donner le coup d'épaule à qqn)

être malade du pouce

1. cf. aimer plus la manche que le bras (1859)

2. cf. avoir les bras cassés (1867)

faire du pouce (20)

voyager en auto-stop; (E) to thumb it

faire jouer du pouce à qqn (1690)

faire payer qqn; (E) to make s.o. put his hand down

jouer du pouce (1690)

payer, débourser; (E) to put one's hand down

lever le pouce (20)

(cf. faire du pouce)

lire (un livre) au pouce

feuilleter, parcourir rapidement; (E) to give a quick thumb through (a book), to thumb through (a book)

manger sur le pouce (1804)

prendre une collation rapide; (E) to put on the nose-bag

mettre les pouces (1789)

(cf. courber le dos)

ne pas se fouler le(s) pouce(s) (19)

(cf. ne pas se fouler le poignet)

on s'en lécherait les cinq doigts et le pouce (1894) (cf. doigt)

pouce! (1883)

assez!, on arrête!; (E) break

rentrer ses pouces (1867)

(cf. raidir le jarret 2)

s'asseoir sur le pouce

n'avoir point de siège; (E) to have nowhere to sit

se lécher les quatre doigts et le pouce de qqch (cf. doigt)

se mordre les pouces (1869)

1. cf. avoir le cœur gros 1

2. cf. se mordre les doigts 2

se tourner les pouces (1869)

(cf. demeurer les bras croisés 1) serrer les pouces à qqn (1640)

contraindre par la force; (E) to put the screws on s.o.

sucer qqch de son pouce

inventer qqch de toutes pièces; (E) to trump up a story

sucer son pouce

se donner un plaisir illusoire; (E) to suck one's thumb

tom-pouce

1. cf. bas de cul (1845)

2. petit parapluie (1924); (E) Tom-Thumb umbrella

tourner ses pouces (1834)

(cf. demeurer les bras croisés 1)

y mettre les quatre doigts et le pouce (18)

(cf. doigt)

\section{POUMON}

cracher ses poumons (1694)

tousser violemment; (E) to cough one's lungs up

crier à pleins poumons (1866)

(cf. crier à pleine gorge)

s'user les poumons (1690)

s'épuiser à crier; (E) to wear one's lungs out (with shouting)

PRUNELLE

jouer de la prunelle (1690)

(cf. faire de l'œil à qqn)

tenir à qqch/ qqn comme à la prunelle de ses

yeux (1306)

(cf. aimer comme ses petits boyaux)

tourner de la prunelle (1864)

(cf. avoir les DOIGTS de pieds en bouquets de violettes)

PYLORE

avoir une crampe au pylore (1867)

(cf. avoir la dent)

RATE

décharger sa rate sur qqn (17)

se mettre en colère sur qqn; (E) to vent one's spleen on s.o.

ne pas se fouler la rate (19)

(cf. ne pas se fouler le poignet)

s'épanouir/ se dilater la rate (17)

(cf. se tenir les côtes)

se mettre la rate au court-bouillon (1950)

(cf. se mettre la cervelle à l'envers)

vous avez bon foie, Dieu vous sauve la rate!

(1690)

(cf. foie)

REIN

avoir bons reins (1690)

(cf. avoir le bras lourd) 
avoir les pieds dans les reins (20)

(cf. avoir les pieds dans le DOS)

avoir les reins forts (1660)

(cf. avoir le bras lourd)

avoir les reins solides (1904)

1. cf. avoir le bras lourd

2. être fort, résistant; (E) to have a strong back

avoir qqch/ qqn sur les reins (1900)

(cf. avoir qqch/ qqn sur les bras)

casser les reins à qqn (20)

1. cf. casser le cou à qqn 1

2. briser l'avenir de qqn; (E) to wreck s.o.'s future

chute des reins (17)

(cf. bas du dos)

département du bas-rein (1867)

(cf. bas du dos; jeu de mots: Bas-Rhin)

donner un tour de reins à qqn

(cf. donner le croc-en-jambe à qqn)

être chaud des reins

être ardent aux plaisirs charnels; (E) to be a hot lover

être faible des reins (1640)

1. cf. être bas de poil

2. avoir peu d'influence, de pouvoir; (E) to

have little influence, little power

frotter les reins à qqn (1867)

(cf. rompre BRAS et jambes à qqn)

huile de reins (1640)

(cf. jus de corps d'homme)

jeu de reins (15)

(cf. jeu de cuisses)

les avoir dans les reins (1926)

(cf. avoir les pieds dans le DOS)

mettre les/ ses reins en besogne (16)

(cf. manger de la chair crue)

ne pas se casser les reins

(cf. ne pas se fouler le poignet)

poursuivre qqn l'épée dans les reins (1690)

1. presser qqn de payer; (E) to urge s.o. to pay

2. prier qqn avec insistance; (E) to press s.o. for sthg

se casser les reins

(cf. se casser le cul)

sonder les reins et les cœurs

(cf. cœur)

tour de reins (1870)

lumbago; (E) lumbago

ROTULE

être sur les rotules (20)

(cf. en avoir plein le cul 1)

mettre qqn sur les rotules (20)

(cf. mettre qqn sur le flanc)
SANG

allumer le sang (1800)

exciter les passions; (E) to excite passions

attraper un coup de sang (19)

(cf. avoir le cœur gros 1)

avoir du sang aux ongles (1640)

(cf. avoir du CEEUR au ventre)

avoir du sang bleu (1923)

être d'origine aristocratique; (E) to have blue blood

avoir du sang dans les veines (1835)

(cf. avoir de nerf)

avoir du sang de navet (1875)

1. cf. avoir un cœur de citrouille

2. être de faible constitution; (E) to have no

blood in one's veins, to have no guts in one

avoir le sang chaud (1636)

être ardent, impétueux; (E) to be hot-

blooded

avoir le sang de (faire qqch) (1901)

(cf. avoir le front de)

bon sang ne peut mentir (1547)

les qualités se transmettent des parents aux enfants; (E) blood will tell

c'est dans le sang (1701)

c'est héréditaire, inné; (E) it runs in the

blood

cela me fait bouillir le sang! (17)

(cf. le sang me bout dans le CORPS)

de sang froid

1. avec calme et fermeté (1569); (E) cool and

collected

2. délibérément, sans motif; (E) in cold

blood

donner jusqu'à la dernière goutte de son sang

(17)

se sacrifier entièrement; (E) to give one's life blood

faire pisser le sang à qqn (1556)

torturer qqn physiquement et moralement;

(E) to torture s.o. bodily and morally

faire tourner les sangs (1847)

1. cf. serrer le cœur

2. cf. se mettre la cervelle à l'envers

fouetter le sang (1784)

activer la circulation, stimuler; (E) to make the blood tingle

garder son sang-froid

se maîtriser; (E) to keep one's hair on, to

keep a level head

glacer le sang dans les veines (1675)

causer un grand effroi; (E) to make one's

blood run cold 
il y a du sang versé entre eux (17) leur inimitié s'est muée en vendetta; (E) there's bad blood/ a blood feud between them

irriter le sang à qqn

(cf. faire la barbe à qqn 6)

je donnerais le plus pur de mon sang/ la

dernière goutte de mon sang pour...) (17)

(cf. je me ferais couper les oreilles pour...)

je le signerais de mon sang

(cf. mettre le doigt au feu)

la voix du sang

les liens de parenté; (E) the call of blood

laver dans le sang (17)

se venger par un meurtre; (E) to wash out in blood

le prix du sang (16)

prix payé pour livrer qqn; (E) blood money

le sang a beaucoup de pouvoir

les liens de parenté sont indestructibles;

(E) blood is thicker than water

le sang lui est monté à la tête (1640)

1. cf. la barbe lui en fume

2. il est rouge de honte; (E) the blood rushed to his facel head

le sang me bout dans le corps/ dans les veines (1640)

(cf. corps)

le sang n'empêche pas de différer de rang

(Corneille, 1651)

la parenté ne garantit pas la hiérarchie sociale; (E) kinship is no guarantee of social status

mettre à feu et à sang (14)

tuer et brûler tout; (E) to put to fire and sword

mettre du baume dans le sang (18)

(cf. mettre du baume au cœur)

mon sang n'a fait qu'un tour (19)

1. cf. le sang me bout dans le CORPS

2. cf. avoir le cœur serré

n'avoir pas de sang dans les veines (1798)

(cf. avoir du sang de navet)

on ne change pas le sang en eau

(cf. le sang a beaucoup de pouvoir)

payer qqch de son sang (1690)

(cf. donner jusqu'à la dernière goutte de son sang)

perdre son sang-froid

ne plus se contrôler; (E) to lose one's hairl head/ nerve; to go off one's head

pisser du sang

(cf. se casser le cul) pisser le sang saigner abondamment; (E) to bleed profusely

pleurer des larmes de sang (1652) verser des larmes amères; (E) to cry bitterly

se battre au premier sang (1694)

se battre jusqu'à la première blessure; (E) to fight until blood is drawn

se cailler le sang (1901)

(cf. avoir le cour gros 1)

se faire/ se payer du bon sang, se payer une

pinte de bon sang (19)

1. rire de bon cœur; (E) to get in a good

belly-laugh

2. s'amuser, se donner du plaisir; (E) to let one's hair down, to kick up one's heels

se faire du mauvais sang (18)

(cf. se mettre la cervelle à l'envers)

se faire un sang d'encre (19)

(cf. ci-dessus)

se ronger les sangs (1875)

(cf. se mettre la cervelle à l'envers)

sentir le sang bouillir dans ses veines

(cf. ne pas tenir dans sa peau 3)

sucer jusqu'au sang (1640)

(cf. sucer jusqu'à la moelle)

suer sang et eau (1588)

(cf. se casser le cul)

tant que le sang coulera dans mes veines

(cf. tant que le cour me battra)

verser le sang (1662)

blesser, tuer; (E) to shed blood

\section{SEIN}

donner le sein (1835)

allaiter; (E) to give the breast, to breast-feed

faire mal aux seins à qqn (20)

(cf. faire la barbe à qqn 6)

mordre le sein de sa nourrice (19)

faire preuve d'ingratitude; (E) to be ungrateful

prendre le sein (1771) téter; (E) to suck

seins en gants de toilette (20) poitrine plate et tombante; (E) flat, drooping breasts

SOURCIL

froncer le sourcil (1640) montrer du mécontentement; (E) to knit/ pucker one's brows, to knit one's eyebrows

SQUELETTE

être maigre comme un squelette (1690)

(cf. la peau lui tient aux côtes)

squelette ambulant (19)

(cf. sac d'os) 
TAILLE

être bien prise de taille

avoir une belle silhouette, être bien faite;

(E) to have a good figure

se gâter la taille (1864)

(cf. tomber sur le CUL et se faire une bosse au ventre)

taille de guêpe (19)

taille très fine; (E) wasp waist

TALON

avoir l'esprit aux talons (1690)

(cf. se fourrer le doigt dans l'œil jusqu'au COUDE)

avoir l'estomac dans les talons (1850)

(cf. avoir la dent)

avoir la cervelle aux talons (1640)

(cf. cervelle)

avoir le cour dans les talons

(cf. avoir chaud au cul)

avoir le pot près des talons (20)

(cf. avoir la tête qui sent des PIEDS)

avoir les talons courts (15)

(cf. avoir la cuisse facile)

ce qu'il a à la tête, il ne l'a pas aux talons

(cf. quand il a qqch à la tête, il ne l'a pas au CUL)

être/ marcher sur les talons de qqn

(cf. coller au cul de qqn 1)

être toujours sur les talons de qqn

(cf. coller au cul de qqn 2)

il fallait qu'il eût les yeux aux talons (1690)

(cf. il fallait qu'il eût les yeux au DERRIÈRE)

j'aime mieux voir vos talons que votre nez!

(1640)

(cf. tournez-moi le dos!)

jouer de l'épée à deux talons (1640)

(cf. prendre ses jambes à son COU)

jouer des talons (1640)

(cf. ci-dessus)

la voiture à talons (1867)

les jambes; (E) the shin-stage

montrer les talons (1330)

(cf. prendre ses jambes à son COU)

montrez-moi vos talons! (1640)

(cf. tournez-moi le dos!)

prendre la voiture des frères Talon (1894)

(cf. aller à pied)

se donner du talon dans le cul (1739)

(cf. se donner des coups de pied dans les CHEVILLES)

se donner du talon/ des talons dans le derrière (cf. derrière)

talon d'Achille (18)

point faible; (E) Achilles' heel tirer des soupirs de ses talons soupirer profondément; (E) to heave a great sigh

tourner les talons (cf. faire haut le corps)

traîner ses talons

(cf. ne pas savoir que faire de sa peau)

voir les talons de qqn être délivré de la présence de qqn; (E) to be rid of s.o.'s presence

\section{TESTICULE}

je voudrais qu'elle m'eût fait un pet aux testicules (1640)

j'aimerais avoir couché avec elle; (E) I'd like

to have slept with her

râtelier à testicules (1640)

(cf. peau)

TÊTE

à la tête du client (1938)

d'après la mine de l'acheteur; (E) according to the buyer's looks

à se cogner la tête contre les murs, il ne vient que des bosses (1897)

(cf. qui s'obstine à mordre un caillou ne réussit qu'à se briser les dents)

à tête reposée

en prenant le temps de la réflexion;

(E) thinking it out carefully

aller la tête haute/ levée (1690)

(cf. marcher le front haut)

après la fête, on gratte la tête (1640)

après la dépense, on se repent; (E) when all the money is up comes remorse

attraper la grosse tête (20)

(cf. ne pas se moucher du coude)

autant de têtes, autant d'avis (Cicéron; 1842)

les opinions diffèrent autant que les individus; (E) so many men, so many minds autant vaudrait se donner de la tête contre un mur (1640)

tout ce qu'on peut faire ne sert à rien;

(E) it's like running one's head against a

brick wall

avoir bonne tête

1. cf. avoir qqch dans la tête et pas au CUL (1640)

2. être intelligent (1894); (E) to have a brain, to have brains, to have guts in one's brain, to have a good head on one's shoulders avoir de la tête

1. cf. avoir qqch dans la tête et pas au CUL

2. cf. avoir la tête sur les ÉPAULES 2

avoir des chambres vides dans la tête (1690)

(cf. avoir des chambres vides dans le cerveau) 
avoir du beurre sur la tête (19) avoir commis quelques méfaits (proverbe juif); (E) to have committed some misdeeds avoir du mercure/ vif-argent dans la tête (17)

1. cf. avoir des chambres vides dans le cerveau

2. cf. avoir la CERVELLE aux talons

avoir du plomb dans la tête (17)

1. cf. avoir la tête sur ÉPAULES 2

2. avoir acquis de l'expérience; (E) to have (cut) one's eyeteeth

avoir du vin dans la tête

(cf. avoir sa barbe)

avoir du yaourt dans la tête (20)

(cf. avoir le cerveau vide)

avoir en tête de (faire qqch)

avoir l'intention de; (E) to have taken it into one's head to (do sthg)

avoir la grosse tête (20)

(cf. avoir les chevilles gonflées)

avoir la tête à l'envers

(cf. avoir la cervelle à l'envers 2)

avoir la tête chaude

1. cf. avoir le cour gros (1640)

2. être prompt à se fâcher (1690); (E) to be a hothead, to be hot-headed

avoir la tête comme une passoire

(cf. avoir une cervelle de lièvre)

avoir la tête dans le cul

(cf. avoir mal aux cheveux)

avoir la tête dans le sac (1960)

(cf. être à cul 1)

avoir la tête de l'emploi (1878)

convenir parfaitement; (E) to be the right

man in the right place

avoir la tête dure (1640)

1. cf. avoir qqch dans la tête et pas au CUL

2. cf. être bête comme ses pieds

avoir la tête fêlée

(cf. avoir la cervelle à l'envers 1)

avoir la tête légère

(cf. avoir la CERVELLE aux talons)

avoir la tête mal faite (1640)

1. cf. avoir la cervelle à l'envers 1

2. cf. s'être levé du pied gauche

3. cf. avoir les glandes 2

4. avoir mal à la tête; (E) to have a headache avoir la tête près du bonnet (16)

(cf. avoir la tête chaude 2)

avoir la tête qui dépasse des cheveux (20)

(cf. cheveu)

avoir la tête qui ne passe plus la porte (20)

(cf. avoir les chevilles gonflées)

avoir la tête qui sent des pieds (20)

(cf. pied) avoir la tête sur les épaules (20)

(cf. épaule)

avoir le feu à la tête (16)

(cf. avoir le cœur gros 1)

avoir les yeux qui sortent de la tête (19)

(cf. ci-dessus)

avoir qqch à la tête (1640)/ dans la tête/ en tête songer continuellement à qqch; (E) to have sthg on the brain

avoir qqch à la tête et pas autre part (18)

(cf. avoir qqch dans la tête et pas au cul)

avoir (toute) sa tête (1773)

jouir de toute sa raison; (E) to have one's

head screwed on

avoir ses têtes

avoir de la sympathie/ de l'aversion pour des personnes déterminées; (E) to have one's

likes/ dislikes for specific persons

avoir un petit pois/ un pois chiche (écrasé) dans

la tête (20)

(cf. avoir le cerveau vide)

avoir un petit vélo dans la tête (20)

avoir une idée fixe, une obsession; (E) to

have an obsession

avoir une bonne tête (1894)

1. cf. avoir bonne tête

2. avoir l'air sympathique; (E) to look a

decent fellow

3. avoir l'air d'un naïf; (E) to look a bit of a mug

avoir une idée dernière la tête (20)

avoir des intentions cachées; (E) to have an idea at the back of one's mind

avoir une tête à coucher dehors

(cf. figure à faire tourner une sauce blanche)

avoir une tête comme une passoire

(cf. avoir une cervelle de lièvre)

baisser la tête

1. cf. perdre la face

2. cf. avoir les glandes 2

belle tête, mais de cervelle point (17)

(cf. cervelle)

blanche gelée, tête lavée

s'il a gelé blanc, il pleuvra dans les trois

jours; (E) white frost heralds rain within three days

bonne tête

personne intelligente; (E) brain(box), clever head

bourrer la tête à qqn (19)

(cf. bourrer le crâne à qqn)

branler la tête (17)

1. dédaigner; (E) to disdain

2. refuser; (E) to refuse

briser la tête à qqn (19)

(cf. casser les oreilles à qqn) 
c'est une (grosse) tête

$$
\text { (cf. c'est un cerveau) }
$$

ça va pas la tête! (20)

1. vous êtes fou!; (E) have you gone crazy!

2. jamais de la vie!; (E) never!

casse-tête

1. bruit assourdissant; (E) ear-splitting noise

2. problème difficile à résoudre; (E) brainracking task, brain teaser/ twister, headache casser la tête à qqn (19)

(cf. casser les oreilles à qqn)

cause à mon cul, ma tête est malade! (20) (cf. cul)

ce qu'il a à la tête, il ne l'a pas aux pieds/ talons (cf. quand il a qqch à la tête, il ne l'a pas au CUL)

cela m'est sorti de la tête

j'ai oublié; (E) it's gone out of my head chercher des poux dans la tête de qqn (1790) faire une mauvaise querelle à qqn; (E) to pick on s.o.

conserver (toute) sa tête garder sa raison, son sang-froid; (E) to keep one's head

coup de tête

action irréfléchie, décision brusque;

(E) impulsive act

courber la tête

(cf. courber le dos)

coûter les yeux de la tête (1867)

(cf. coûter la peau du CUL)

crier à tue-tête (16)

(cf. crier à pleine gorge)

cul par-dessus tête (1640)

(cf. cul)

de la tête aux pieds

(cf. pied)

de tête

mentalement; (E) in one's head

dépasser qqn de la tête

être plus grand que qqn; (E) to stand a head taller than s.o., to stand head and shoulders over s.o., to top s.o. by a head

deux têtes dans le même bonnet/ dans un bonnet (17)

(cf. n'être qu'un en deux corps)

dire ce qui passe par la tête parler sans réserve; (E) to talk off the top of one's head, to shoot off one's mouth

donner de cul et de tête (16) (cf. cul)

donner sa tête à couper

(cf. mettre le doigt au feu)

dresser la tête

prendre de l'assurance; (E) to gain self- assurance

échauffer la tête à qqn

1. cf. faire monter la moutarde au nez de qqn

2. monter l'imagination de qqn; (E) to work on s.o.'s feelings

en avoir par-dessus la tête

1. cf. jusqu'au cou (1640)

2. cf. en avoir plein le cul (1690)

en tête-à-tête (18)

seul à seul, en privé; (E) eyeball to eyeball, tête-à-tête

enfoncer qqch dans la tête à qqn

(cf. enfoncer qqch dans le crâne à qqn)

être comme le bonnetier, n'en faire qu'à sa tête (1690)

(cf. avoir qqch dans la tête et pas au CUL)

être tombé sur la tête

(cf. avoir la cervelle à l'envers)

faire de sa tête massue (1690)

se donner de la peine pour réussir; (E) to

take great pains to reach success

faire dresser les cheveux sur la tête (1640)

(cf. cheveu)

faire la forte/ mauvaise tête (19)

être indiscipliné, refuser d'obéir; (E) to be heavy/ hot on hand

faire la tête

(cf. faire une tête longue d'un BRAS)

faire la tête à qqn

(cf. faire l'épaule rennoise à qqn)

faire sa tête (19)

(cf. faire son crâne)

faire tête à qqn (1640)

(cf. tenir pied à qqn)

faire tête-bêche (1864)

pratiquer le double coït buccal; (E) to do sixty-nine

faire une grosse tête à qqn (1950)

(cf. casser la figure à qqn)

faire une tête

1. cf. faire une tête longue d'un BRAS

2. cf. demeurer bouche bée

3. frapper le ballon de la tête (football, 1905); (E) to head the ball

faire/ filer une tête au carré à qqn (20)

(cf. casser la figure à qqn)

femme de tête

femme capable, organisée, volontaire;

(E) capable, wilful woman

fendre la tête à qqn (19)

(cf. casser les oreilles à qqn)

foncer tête baissée (16)

agir sans réfléchir; (E) to jump in feet first (US), to go at it bald-headed, to rush

headlong into 
forte tête

1. esprit qui raisonne bien (1690); (E) powerful reasoner

2. caractère insubordonné (1904); (E) unruly fellow

3. meneur; (E) ringleader

gager sa tête (1640)

(cf. mettre le doigt au feu)

gratter sa tête (1640)

1. cf. se mordre les doigts 2

2. cf. avoir le cœur gros 1

grosse tête

intellectuel; (E) highbrow, egghead

grosse tête, peu de sens (1640)

(cf. belle tête, mais de CERVELLE point)

hocher la tête (17)

(cf. branler la tête)

il a chaussé sa tête (1640)

(cf. quand il a qqch à la tête, il ne l'a pas au CUL)

il a mal à la tête (1690)

(cf. on connaît à ses yeux que sa tête n'est pas cuite)

il ne faut jamais trembler qu'on ne voie sa tête à ses pieds (1640)

(cf. pied)

il ne peut mettre cela dans sa tête

il ne peut croire / imaginer cela; (E) he can't get it into his head

il y a plus dans deux têtes que dans une deux avis valent mieux qu'un; (E) two heads are better than one

il y va de cul et de tête, comme une corneille qui abat des noix (1690)

(cf. cul)

j'en donnerais ma tête à couper

(cf. mettre le doigt au feu)

jeter qqch à la tête de qqn (1672)

1. cf. jeter qqchose à la face de qqn

2. offrir avec trop d'empressement; (E) to offer too eagerly

l'orgueil s'installe au large dans une tête vide

(Desbillons, 1779)

les sots sont les plus vaniteux des hommes;

(E) vanity feeds on ignorance

la sagesse n'est pas enfermée dans une tête (1750)

(cf. il y a plus dans deux têtes que dans une)

la tête a emporté le cul (1690)

(cf. cul)

la tête et les jambes (1926)

(cf. jambe)

la tête la première

hardiment, inconsidérément; (E) head first/

foremost la tête lui fait bien mal (1640)

il est plein de ressentiment; (E) he is very resentful

la tête me fend (1640)

j'ai grand mal de tête; (E) I've got a splitting headache

la tête me tourne

je suis pris de vertiges; (E) my head is

spinning/ swimming

laver la tête à qqn (1538)

(cf. prendre qqn aux cheveux)

le sang lui est monté à la tête (1640)

(cf. sang)

le succès lui a tourné la tête/ lui est monté à la

tête

le succès l'a rendu prétentieux; (E) success has gone to his head/ has turned his head

le temps blanchit les têtes sans mûrir la raison on fait des folies à tout âge; (E) the brains don't lie in the beard, the head grey and no brains yet

lever la tête

(cf. dresser la tête)

mal de tête (1597)

céphalée; (E) headache

mal de tête veut (re)paître (1640)

il faut manger pour soulager un mal de tête;

(E) eating will soothe a headache

manger des petits pâtés (1640)/ la soupe (20)

sur la tête de qqn

(cf. dépasser qqn de la tête)

marcher la tête haute/ levée (1690)

(cf. marcher le front haut)

marcher sur la tête

agir en dépit du bon sens; (E) to act against common sense

mauvaise tête (1536)

(cf. forte tête 2)

mauvaise tête et bon cœur

(cf. cœur)

mettre la tête à la fenêtre (18)

(cf. jouer à la main chaude)

mettre la tête à l'étau (1948)

(cf. se mettre une fausse barbe)

mettre la tête au carré à qqn

(cf. casser la figure à qqn)

mettre la tête entre les deux oreilles à qqn

(cf. oreille)

mettre la tête où l'on a les pieds (1640)

(cf. mettre le cul en haut)

mettre sa tête à couper

(cf. mettre le doigt au feu)

mettre un beau panache sur la tête de son mari (1690)

cocufier son époux; (E) to put a bone in the hood, to hurt in the head 
mettre une tête à prix (1690) offrir une récompense pour la capture de qqn; (E) to put a price on s.o.'s head

monter à la tête (1560) étourdir, griser; (E) to go to one's head, to turn one's head

n'avoir pas de tête

(cf. avoir une cervelle de lièvre)

n'avoir pas la tête bien cuite (1640)

(cf. avoir la CERVELLE aux talons)

n'avoir plus sa tête à soi/ plus toute sa tête (cf. avoir la cervelle à l'envers 1 )

n'en faire qu'à sa tête (15) agir à sa guise, suivre son caprice; (E) to have one's own way

ne pas avoir la tête à ce qu'on fait être distrait; (E) to be absentminded ne (pas) savoir où donner de la tête (1586) 1. cf. en avoir par-dessus les épaules 2 2. ne pas savoir par où commencer; (E) not to know what to put one's hand to first ne te paie pas ma tête! (19) ne te moque pas de moi; (E) don't give me any of your lip!

on connaît à ses yeux que sa tête n'est pas cuite (1640)

(cf. œil)

on lui a mis sa tête à ses pieds (1640) (cf. faire la barbe à qqn 5)

on ne peut lui ôter cela de la tête on ne peut l'en dissuader; (E) it can't be put out of his head

où ai-je la tête! comment n’y ai-je pas pensé?; (E) what am I thinking about!

par-dessus la tête (cf. jusqu'au cou)

par tête (17) par personne; (E) (so much) a head parle à mon cul, ma tête est malade! (cf. baisez-moi au cul, la BOUCHE est malade)

payer de sa tête payer de sa vie; (E) to pay with one's life payer les yeux de la tête (cf. œil)

perdre la tête

1. cf. jouer à la main chaude

2. cf. avoir des chambres vides dans le cerveau

3. cf. perdre son sang-froid

petite tête! (20)

formule d'affection; (E) affectionate term of address piquer une tête

plonger dans l'eau; (E) to take a header

porter à la tête (16)

(cf. monter à la tête)

prendre la tête à qqn (20)

(cf. faire la barbe à qqn 6)

quand il a qqch à la tête, il ne l'a pas au cul (1640)

(cf. cul)

quand on n'a pas de/ la tête, il faut avoir des jambes (19)

(cf. jambe)

qui a bonne tête ne manque pas de chapeaux (1842)

l'homme habile trouve toujours ce dont il a besoin; (E) a resourceful man will always

find what he needs

redresser/ relever la tête

reprendre de l'assurance; (E) to recover one's self-assurance

rompre la tête à qqn (1458)

(cf. faire la barbe à qqn 6)

sa tête donne bien du mal à ses pieds (1690)

(cf. on connaît à ses YEUX que sa tête n'est pas cuite)

sa tête lui donne bien de la peine (1640)

(cf. avoir des chambres vides dans le cerveau)

savonner la tête à qqn (17)

(cf. prendre qqn aux cheveux)

se casser/ creuser la tête (17)

(cf. s'alambiquer le cerveau)

se cogner la tête contre le mur (1935)

(cf. se taper la tête contre le mur)

se donner de la tête contre le mur (1640)

1. cf. avoir le cœur gros 1

2. être au comble du désespoir; (E) to be utterly desperate

se faire laver la tête (16)

(cf. avoir sur les doigts)

se faire une tête (1867)

se grimer (pour un rôle); (E) to make up

(for a character)

se jeter à la tête de qqn (17)

1. faire des avances excessives à qqn; (E) to

make up to s.o.

2. offrir ses services à bon marché; (E) to

offer one's services at low price

se mettre dans la tête/ en tête (de faire qqch)

décider de faire qqch); (E) to get/ take it into one's head (to do sthg)

se mettre la tête à l'envers

(cf. se mettre la cervelle à l'envers)

se mettre martel en tête (20)

(cf. se mettre la cervelle à l'envers) 
se monter la tête

1. cf. se monter le cou 2 (1798)

2. cf. avoir le cœur gros 1

3. se donner du courage par la boisson

(1867) ; (E) to find courage in drinking

se payer la tête de qqn (1896)

(cf. faire la barbe à qqn 4)

se taper la tête (19)

(cf. se caler les amygdales)

se taper la tête contre les murs (18)

perdre sa peine, se démener en vain; (E) to

bang/ bash/ beat/ knock/ run one's head against/ into a (brick) wall

tel a de beaux yeux à la tête qui n'en verra pas la fête (1640)

(cf. œil)

tenir la tête à qqn (1640)

(cf. prêter son bras à qqn)

tenir tête à qqn (16)

(cf. tenir pied à)

tête à claques (19)

personne agaçante, déplaisante;

(E) unpleasant, irritating person

tête à l'évent (1640)

(cf. cerveau à bourrelets 2 )

tête à l'huile (1889)

figurant amateur (au théâtre); (E) super

tête à perruque (18)

1. cf. cervelle à double rebras

2. cf. vieux cul

tête-à-tête

1. cf. partie de jambes en l'air (1864)

2. situation de deux personnes se trouvant seule à seule (1549); (E) tête-à-tête

tête à $\mathrm{x}(19)$

doué des mathématiques; (E) s.o. with a

head for maths

tête baissée (1640)

1. courageusement, résolument; (E) bald-

headed

2. aveuglément, sans réfléchir; (E) feet first

(US), hand over head

tête basse

honteusement, l'air abattu ; (E) with a hangdog look

tête-bêche (1820)

en sens inverse l'un de l'autre; (E) head to

foot, head to tail

tête brûlée

(cf. cerveau brûlé)

tête carrée (19)

1. personne droite et ferme; (E) straight-

forward, outspoken person

2. personne butée, têtue; (E) pighead

3. Allemand; (E) squarehead tête cerclée (1918)

officier; (E) brass hat

tête chaude personne irascible, ombrageuse; (E) hothead

tête couronnée

souverain; (E) crowned head

tête de bois (1948)

1. cf. cervelle à double rebras

2. cf. tête carrée 2

tête de buis (1867)

calvitie; (E) barefoot dome

tête de choucroute (19)

(cf. tête carrée 3)

tête de cire (1888)

(cf. tête de buis)

tête de cochon

(cf. tête carrée 2)

tête d'enterrement

mine triste; (E) face as long as a funeral,

face like an undertaker

tête de fou ne blanchit pas

les fous ne connaissent pas les soucis;

(E) mad men do not get grey hair because they do not worry

tête de lard (20)

(cf. tête carrée 2)

tête de linotte (1640)

(cf. cerveau à bourrelets 2)

tête de mule (20)

(cf. tête carrée 2)

tête de nœud (1946)

(cf. cervelle à double rebras)

tête de Turc (1867)

bouc émissaire, souffre-douleur; (E) scape-

goat, whipping-boy

tête de veau

1. cf. tête de buis (1881)

2. condamné aux travaux forcés (1897);

(E) convict

tête d'œuf (19)

1. cf. tête de buis

2. cf. grosse tête

tête en l'air

(cf. cerveau à bourrelets 2)

tête éventée (1640)

(cf. ci-dessus)

tête légère

(cf. ci-dessus)

tête nickelée/ pelée (1888)

(cf. tête de buis)

tête verte (1640)

(cf. cerveau à bourrelets 2)

tomber la tête la première

tomber en avant; (E) to fall head first/ head

foremost/ headlong 
tomber sur la tête

(cf. avoir des chambres vides dans le cerveau)

tourner la tête

(cf. monter à la tête)

tourner la tête à qqn

inspirer une passion à qqn, affoler qqn ;

(E) to turn s.o.'s head

tourner les yeux à la tête (1640)

(cf. tourner de l'œil)

tourner tête (1640)

(cf. faire face 1)

tous ceux qui portent des cornes n'ont pas le

bonnet hors de la tête (1559)

le mari trompé n'est pas toujours fâché;

(E) a cuckold is not always sorry

tout le reste est peu sain quand la tête est

malsaine (1579)

le mal est contagieux; (E) when the head aches, all the body is the worse

une tête bien faite est mieux qu'une tête bien pleine (Montaigne, 1580)

l'éducation prime l'instruction; (E) a good

breeding is better than schooling

y aller tête baissée

(cf. foncer tête baissée)

\section{TORSE}

bomber le torse

prendre un air avantageux; (E) to stick out one's chest

faire des effets de torse

(cf. ci-dessus)

se modeler le torse

(cf. se caler les amygdales)

TRIPE

avoir des tripes (20)

(cf. avoir du CEUR an ventre)

avoir la tripe patriotique (20)

être profondément patriote; (E) to be a fullblooded patriot

c'est à faire vomir tripes et boyaux (1690) (cf. boyau)

faire qqch avec ses tripes

faire qqch avec conviction; (E) to put one's guts in it

mettre les tripes à l'air/ au soleil à qqn (16) tuer qqn à l'arme blanche; (E) to rip s.o. up rendre tripes et boyaux (1640) (cf. boyau)

se laver les tripes (1640) (cf. s'arroser les amygdales)

sentir qqch dans ses tripes (20)

ressentir qqch profondément; (E) to feel sthg in one's bones, to have a gut reaction

\section{TRONC}

ne pas se casser le tronc (20)

(cf. ne pas se fouler le poignet)

se casser le tronc (1926)

(cf. s'alambiquer le cerveau)

se taper le tronc (20)

(cf. se caler les amygdales)

tronc (1026)

tête; (E) brain box, brain-pan, head-piece

VAGIN

se (faire) graisser le vagin (1861)

(cf. manger de la chair crue)

VEINE

avoir du jus de navet dans les veines

(cf. avoir un cœur de citrouille)

avoir du sang dans les veines (1835)

(cf. avoir du nerf)

avoir du vif-argent dans les veines

(cf. avoir du mercure aux fesses)

avoir le feu dans les veines (18)

(cf. avoir le sang chaud)

glacer le sang dans les veines (1675) (cf. sang)

je vous saignerai une autre veine! (1640)

je vous aurai d'une autre façon; (E) I'll try you some other way!

le sang me bout dans les veines (1640)

(cf. le sang me bout dans le CORPS)

n'avoir pas de sang dans les veines (1798)

(cf. avoir du sang de navet)

qui voit ses veines voit ses peines (1894)

les sujets d'affliction augmentent avec l'âge;

(E) pain and anguish wring the brow

se saigner aux quatre veines (20)

payer un maximum; (E) to bleed oneself white

sentir le sang bouillir dans ses veines (1694)

(cf. ne pas tenir dans sa peau 3 )

tant que le sang coulera dans mes veines (cf. tant que le CEEUR me battra dans le ventre)

\section{VENTRE}

à ventre soûl cerises amères (17)

les meilleures choses perdent leur prix quand on est rassasié ; (E) to a full body all meat is bad

avoir des grenouilles dans le ventre (1640)

1. cf. avoir le gosier sec

2. avoir des borborygmes; (E) to have

rumblings in one's bowels

avoir du chien dans le ventre (1867)

(cf. avoir du CCEUR au ventre)

avoir du cour au ventre (15)

(cf. cœur) 